\title{
Surface-Water Quality-Assurance Plan for the U.S. Geological Survey Washington Water Science Center
}

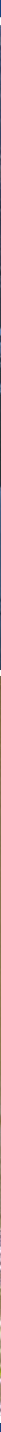

Open-File Report 2016-1020

Version 1.1, August 2017

U.S. Department of the Interior

U.S. Geological Survey 
Cover:

Left: Photograph of a U.S. Geological Survey Hydrologic Technician taking a discharge measurement at the South Fork Sultan River near Sultan, Washington (12137290).

Photograph taken by John Greene, U.S. Geological Survey, October 21, 2015.

Top right: Photograph of an acoustic Doppler current profiler used to measure

discharge on the Columbia River below Priest Rapids Dam, Washington. Photograph taken by Keven Wright, U.S. Geological Survey, July 12, 2012.

Bottom right: Photograph of a U.S. Geological Survey Hydrologic Technician taking a discharge measurement at Crab Creek near Beverly, Washington. Photograph taken by Kevin Wright, U.S. Geological Survey, August 3, 2013. 


\section{Surface-Water Quality-Assurance Plan for the U.S. Geological Survey \\ Washington Water Science Center}

By Mark C. Mastin

Open-File Report 2016-1020

Version 1.1, August 2017 


\section{U.S. Department of the Interior SALLY JEWELL, Secretary}

\section{U.S. Geological Survey \\ Suzette M. Kimball, Director}

U.S. Geological Survey, Reston, Virginia: 2016

First release: 2016

Revised: August, 2017, ver. 1.1

For more information on the USGS—-the Federal source for science about the Earth, its natural and living resources, natural hazards, and the environment-visit http://www.usgs.gov/ or call 1-888-ASK-USGS (1-888-275-8747).

For an overview of USGS information products, including maps, imagery, and publications, visit http://www.usgs.gov/pubprod/.

Any use of trade, firm, or product names is for descriptive purposes only and does not imply endorsement by the U.S. Government.

Although this information product, for the most part, is in the public domain, it also may contain copyrighted materials as noted in the text. Permission to reproduce copyrighted items must be secured from the copyright owner.

Suggested citation:

Mastin, M.C., 2017, Surface-water quality-assurance plan for the U.S. Geological Survey Washington Water Science Center (ver. 1.1, August 2017): U.S. Geological Survey Open-File Report 2016-1020, 85 p., http://dx.doi.org/10.3133/ofr20161020.

ISSN 2331-1258 (online) 


\section{Contents}

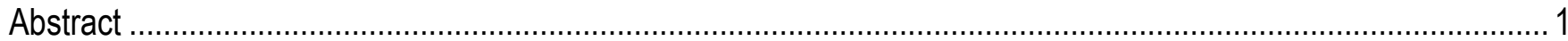

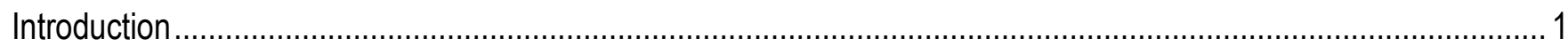

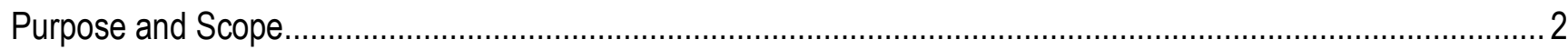

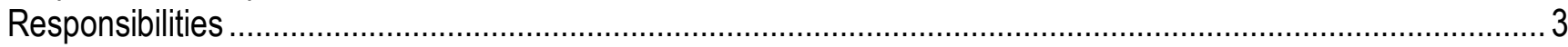

Washington Water Science Center Director ......................................................................................... 3

Washington Water Science Center Assistant Director for Hydrologic Data (Data Chief) .................................. 4

Washington Water Science Center Associate Director for Hydrologic Studies (Studies Chief) .......................... 4

Washington Water Science Center Surface-Water Database Administrator ..................................................... 4

Washington Water Science Center Surface-Water Specialist .................................................................... 4

Washington Water Science Center Hydroacoustic Specialist.................................................................

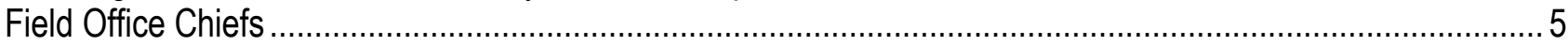

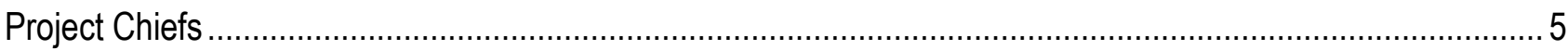

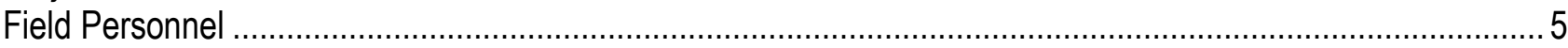

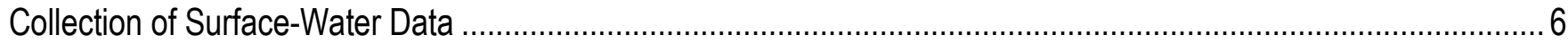

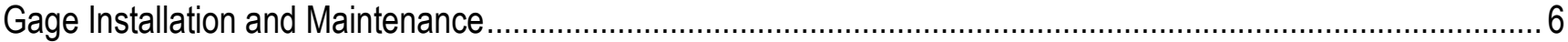

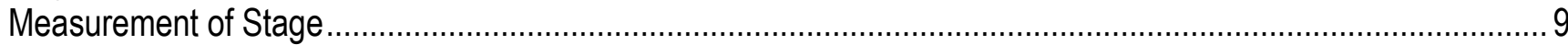

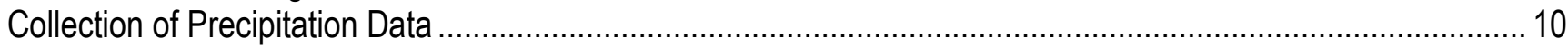

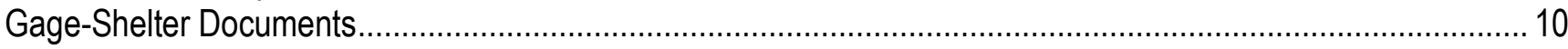

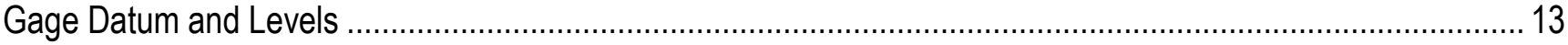

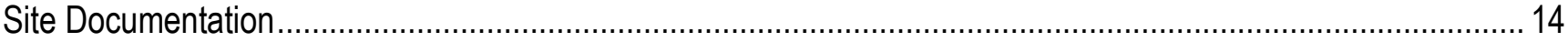

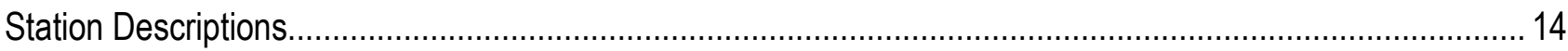

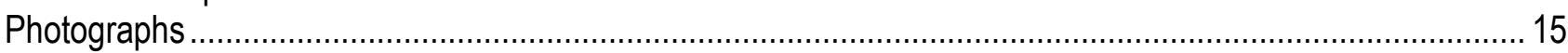

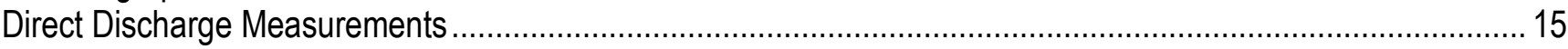

Depth Criteria for Meter Selection and Velocity-Measurement Method ...................................................... 17

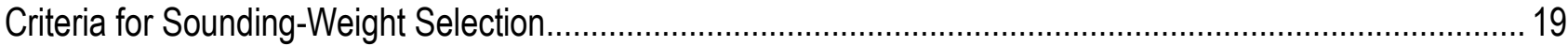

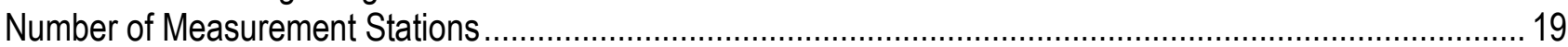

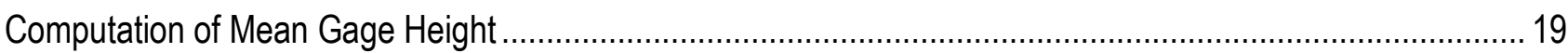

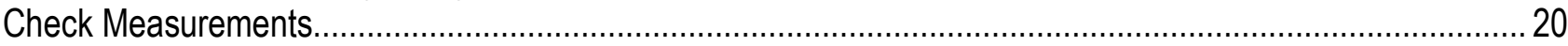

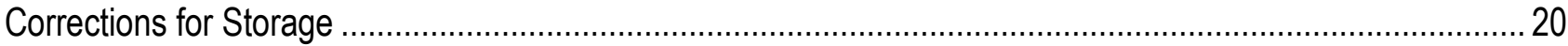

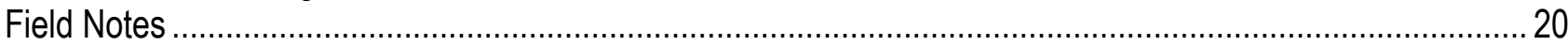

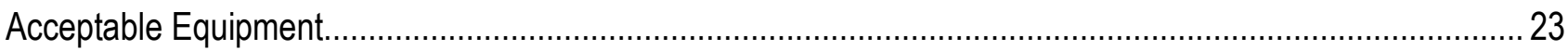

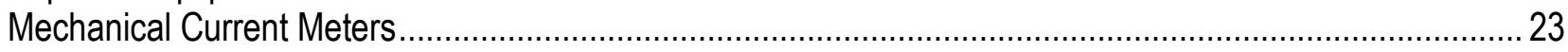

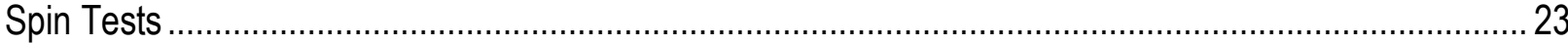

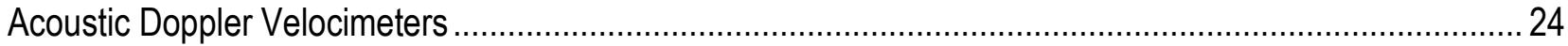

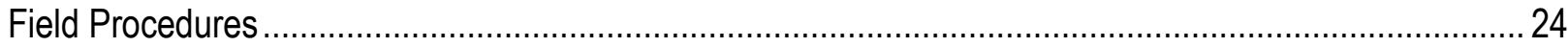

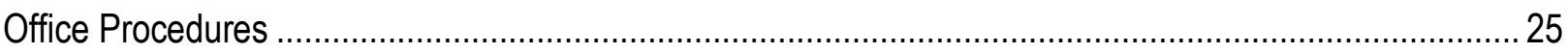

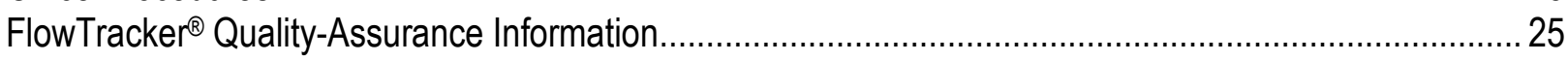

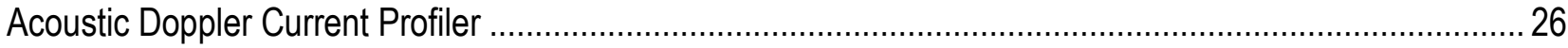

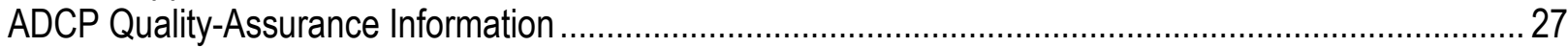

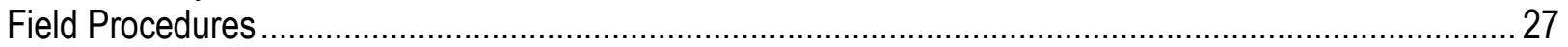

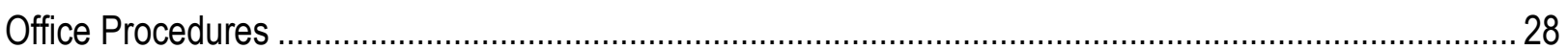




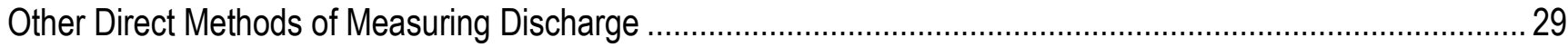

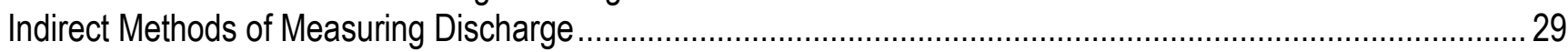

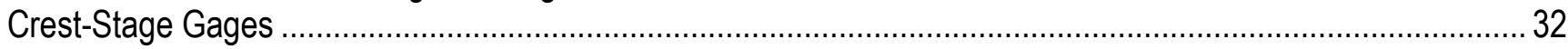

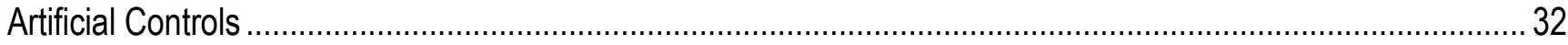

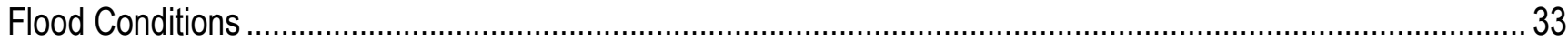

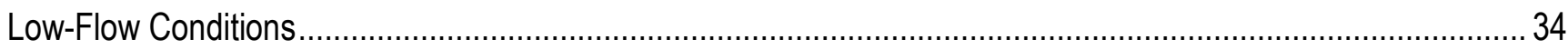

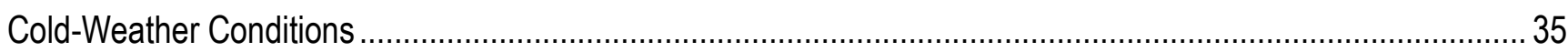

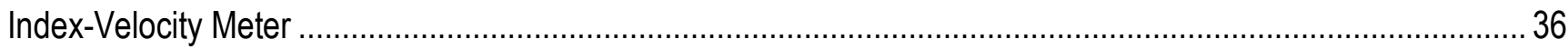

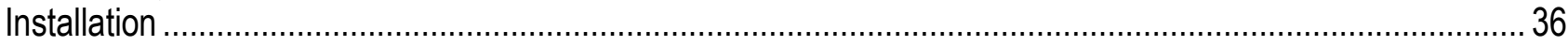

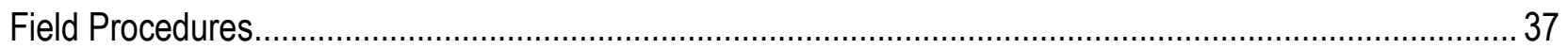

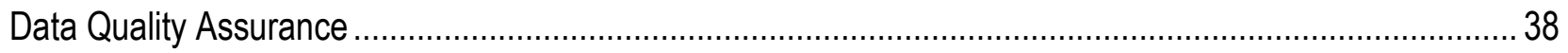

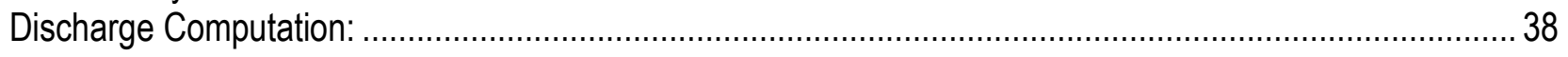

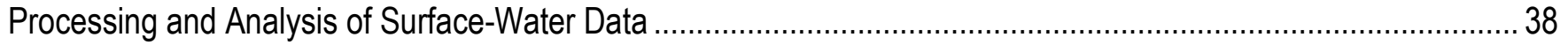

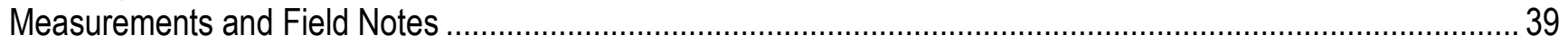

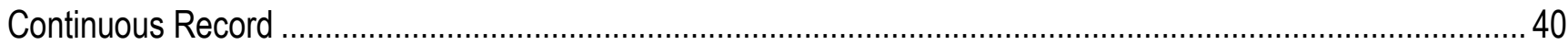

Procedures for Computing, Reviewing, and Publishing Records .................................................................40

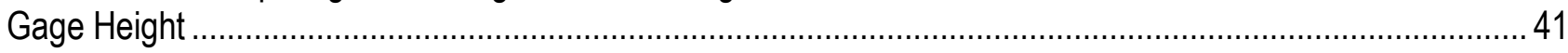

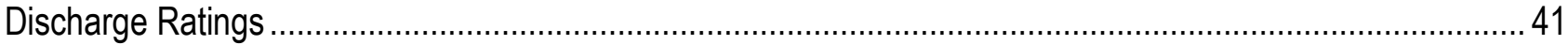

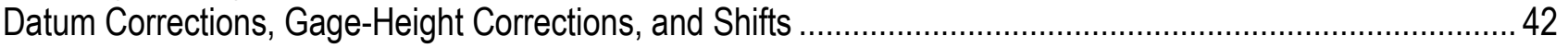

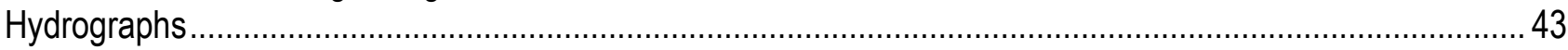

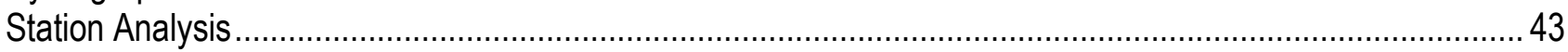

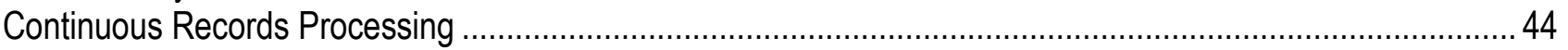

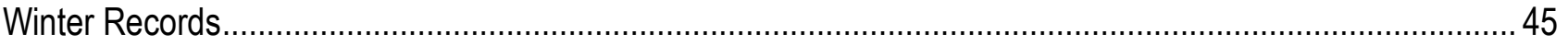

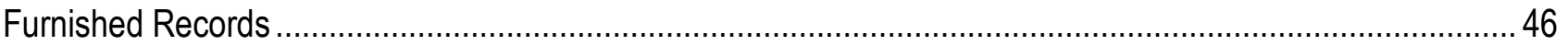

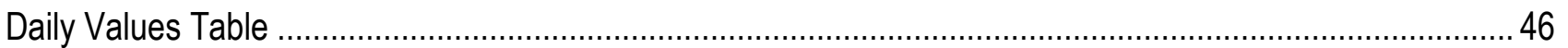

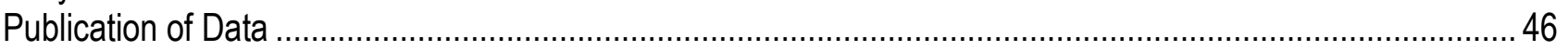

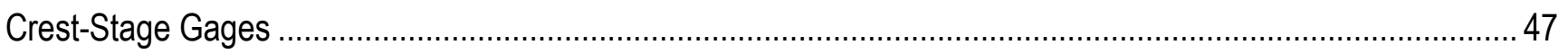

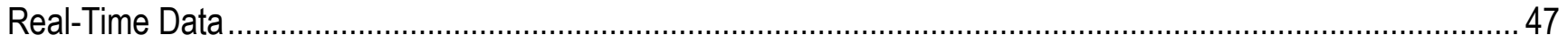

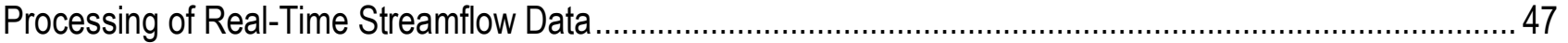

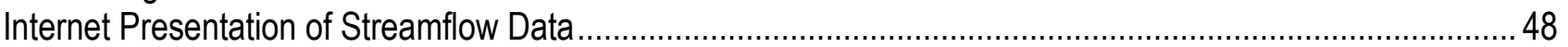

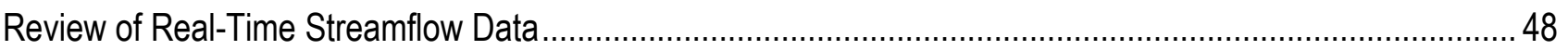

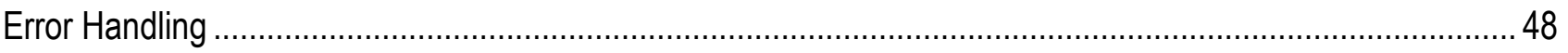

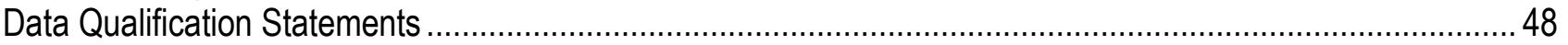

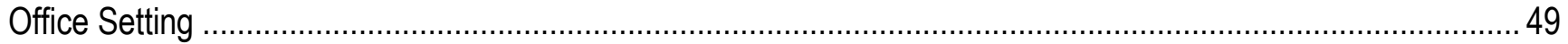

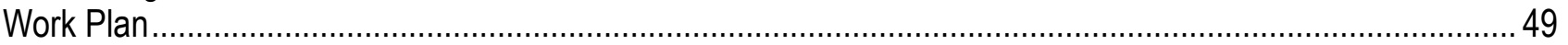

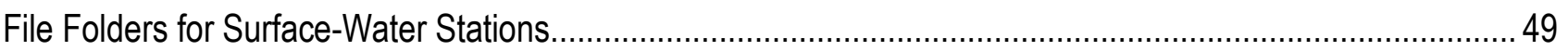

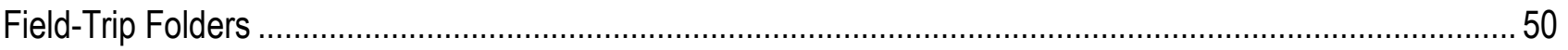

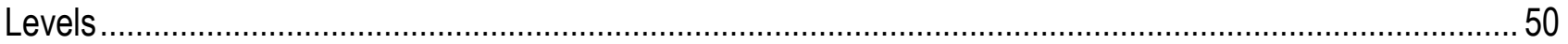

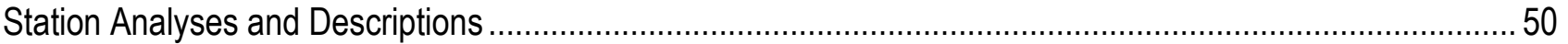

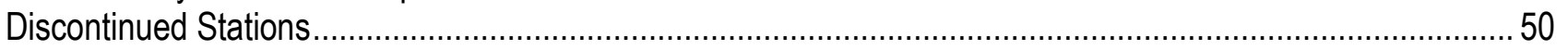

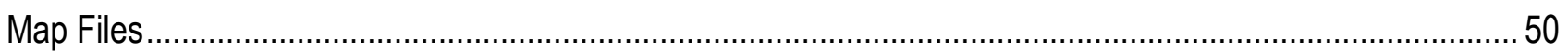

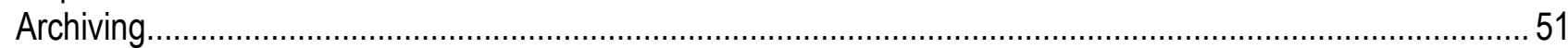

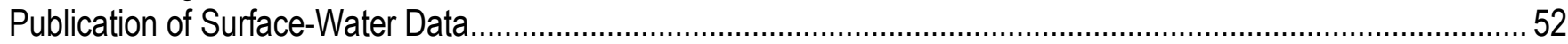

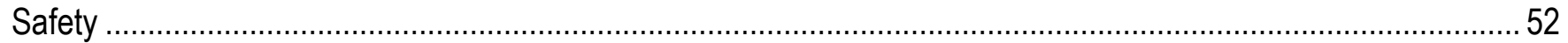

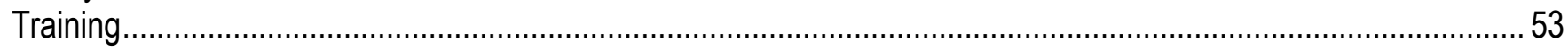

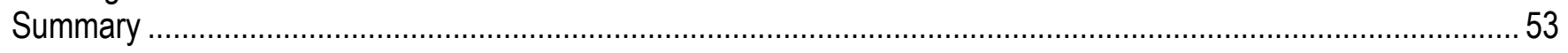

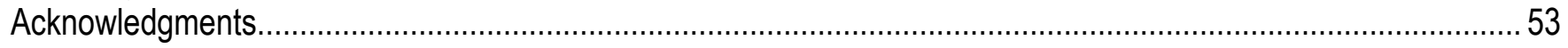


References Cited

Appendix A. Office of Surface Water, Quality of Water Branch, Water Resources Division Memorandums, and Informational and Technical Notes Cited

Appendix B. Washington Water Science Center Note Sheets for Recording Surface-Water Data ...........................59

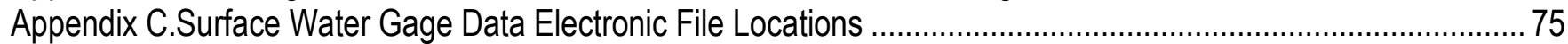

Appendix D. Acoustic Doppler Current Profiler (ADCP) Wading Limitations and Precautions................................78 Appendix E. Washington Water Science Center Directory Structure for Surface Water Electronic Field Data and Record Reviews

\section{Figures}

Figure 1. Organization of the U.S. Geological Survey Washington Water Science Center.................................... 3

Figure 2. Activities for gaging station operation and maintenance. .............................................................. 8

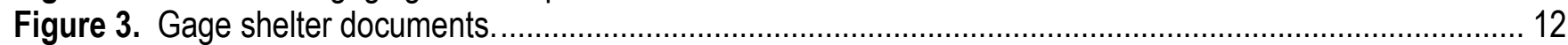

Figure 4. Guidelines for direct measurement of discharge using a FlowTracker ${ }^{\circledR}$ or mechanical current meter.... 16

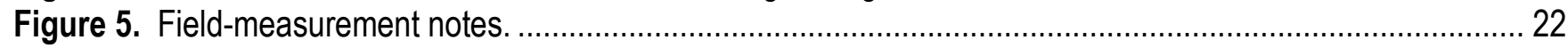

\section{Tables}

Table 1. Current meter and velocity-measurement method for ranges of depth.

Table 2. Weight on bottom coefficient to adjust measured velocity of a vertical to mean velocity for indicated water depth, and corresponding position of the current meter above the sounding weight.

\section{Conversion Factors}

Inch/Pound to International System of Units

\begin{tabular}{|c|c|c|}
\hline Multiply & By & To obtain \\
\hline \multicolumn{3}{|c|}{ Length } \\
\hline inch (in.) & 2.54 & centimeter $(\mathrm{cm})$ \\
\hline inch (in.) & 25.4 & millimeter (mm) \\
\hline foot (ft) & 0.3048 & meter $(\mathrm{m})$ \\
\hline \multicolumn{3}{|c|}{ Mass } \\
\hline pound, avoirdupois (lb) & 0.4536 & kilogram (kg) \\
\hline \multicolumn{3}{|c|}{ Flow rate } \\
\hline foot per second (ft/s) & 0.3048 & meter per second $(\mathrm{m} / \mathrm{s})$ \\
\hline
\end{tabular}

Temperature in degrees Celsius $\left({ }^{\circ} \mathrm{C}\right)$ may be converted to degrees Fahrenheit $\left({ }^{\circ} \mathrm{F}\right)$ as ${ }^{\circ} \mathrm{F}=\left(1.8 \times{ }^{\circ} \mathrm{C}\right)+32$. 


\section{Abbreviations}

$\begin{array}{ll}\text { ADAPS } & \text { Automated DAta Processing System } \\ \text { ADCP } & \text { Acoustic Doppler Current Profiler } \\ \text { ADV } & \text { acoustic Doppler velocimeter } \\ \text { ADVM } & \text { acoustic Doppler velocity meter } \\ \text { CRP } & \text { Continuous Records Processing } \\ \text { CSG } & \text { crest-stage gage } \\ \text { DCP } & \text { Data Collection Platform } \\ \text { DBA } & \text { database administrator } \\ \text { DEM } & \text { digital elevation model } \\ \text { EDL } & \text { Electronic Data Logger } \\ \text { FRC } & \text { Federal Records Center } \\ \text { GPS } & \text { Global Positioning System } \\ \text { HIF } & \text { Hydrologic Instrumentation Facility } \\ \text { HWM } & \text { high-water mark } \\ \text { IT } & \text { Information Technology } \\ \text { JHAs } & \text { job hazard analyses } \\ \text { NWIS } & \text { National Water Information System } \\ \text { QA } & \text { Quality-Assurance } \\ \text { OSW } & \text { Office of Surface Water } \\ \text { PDA } & \text { personal digital assistant } \\ \text { RMS } & \text { Records Management System } \\ \text { SIMS } & \text { Site Information Management System } \\ \text { SLAP } & \text { Site Levels Archiving and Processing } \\ \text { SNR } & \text { Signal-to-Noise Ratio } \\ \text { SWAMI } & \text { Surface Water Measurement and Inspection } \\ \text { USGS } & \text { U.S. Geological Survey } \\ \text { WSC } & \text { Water Survey of Canada } \\ \text { WAWSC } & \text { Washington Water Science Center } \\ \text { WWFO } & \text { Western Washington Field Office } \\ \text { WSPRO } & \text { Water-Surface Profile Computation model } \\ & \\ \text { WH } & \end{array}$




\title{
Surface-Water Quality-Assurance Plan for the U.S. Geological Survey Washington Water Science Center
}

By Mark C. Mastin

\begin{abstract}
This Surface-Water Quality-Assurance Plan documents the standards, policies, and procedures used by the U.S. Geological Survey Washington Water Science Center (WAWSC) for activities related to the collection, processing, storage, analysis, and publication of surface-water data. This plan serves as a guide to all WAWSC personnel involved in surface-water data activities, and changes as the needs and requirements of the WAWSC change. Regular updates to this plan represent an integral part of the quality-assurance process. In the WAWSC, direct oversight and responsibility by the hydrographer(s) assigned to a surface-water station, combined with team approaches in all work efforts, assure highquality data, analyses, reviews, and reports for cooperating agencies and the public.
\end{abstract}

\section{Introduction}

Congress established the U.S. Geological Survey (USGS) on March 3, 1879, to provide a permanent Federal agency to perform the systematic and scientific "classification of the public lands, and examination of the geologic structure, mineral resources, and products of the national domain." There are six mission areas in the USGS:

1. Ecosystems,

2. Climate and Land-Use Change,

3. Natural Hazards,

4. Energy and Minerals and Environmental Health,

5. Core Science Systems, and

6. Water.

The Water Mission Area includes surface-water activities in Washington State. Federal, State, Tribal, and local agencies use surface-water information, including streamflow, stage, and precipitation data, for resources planning and management and flood warning and monitoring throughout the State. The public also uses stage and streamflow data for recreational purposes such as fishing and boating. 
The Washington Water Science Center (WAWSC) Surface-Water Quality-Assurance (QA) Plan uses the basic framework presented in "A Workbook for Preparing Surface-Water Quality-Assurance Plans for WAWSCs of the U.S. Geological Survey, Water Resources Discipline” (Arvin, 1995), released by Office of Surface Water (OSW) Technical Memorandum 95.03. Differences between the workbook and the WAWSC QA Plan include text additions and deletions, rewording of the text, reorganization of some sections, and inclusion of figures for quick reference. The section of the QA Plan that addresses the quality assurance of real-time data follows the guidelines given in an addendum to the Workbook, released by OSW Technical Memorandum 99.07. This Plan is based on a previous QA Plan with a similar title (the "Washington District" is now known as the "Washington Water Science Center") by Kresch and Tomlinson (2004). Since that prior QA Plan was published, some significant changes in equipment and procedures have occurred that necessitated a significant revision to the plan. Rather than simply calling this a new version as was done in the past with minor changes to the text, it was felt that it would be more appropriate to publish the updated QA Plan as a new report.

\section{Purpose and Scope}

The USGS Washington Water Science Center's (WAWSC) Surface-Water Quality-Assurance Plan (QA Plan) documents the standards, policies, and procedures used by the WAWSC for activities related to the collection, processing, storage, analysis, and publication of surface-water data. This QA Plan identifies responsibilities for ensuring that stated policies and procedures are carried out; serves as a guide for WAWSC personnel involved in surface-water activities and as a resource for identifying memorandums, publications, and other literature that describe in more detail associated techniques and requirements; and provides information and guidelines for cooperating agencies and to agencies that furnish data to the WAWSC.

The QA Plan encompasses discussions of the policies and procedures followed by the WAWSC for the collection, processing, analysis, storage, and publication of surface-water data. The primary types of surface-water data addressed by this QA Plan include stage (water-surface elevation), streamflow, and precipitation data collected by the field offices and the Hydrologic Studies Program of the WAWSC. Other meteorological data collected by the WAWSC, such as snowpack characteristics and evapotranspiration, are not specifically addressed herein. Surface-water quality data, including sediment and turbidity, also are not specifically addressed herein; they are addressed in the WAWSC Quality Assurance Plan for Water Quality Activities (Wagner and others, 2007.) This QA Plan addresses issues related to the management of the computer database and employee safety and training. Although procedures and products of surface-water data collected for interpretive projects are subject to the criteria presented in this report, Project Chiefs may need to augment this QA Plan with a projectspecific quality-assurance plan for specialized surface-water activities not addressed herein. The WAWSC Surface-Water Specialist reviews the WAWSC QA Plan at least once every 3 years to assure that responsibilities and methodologies are kept current and to assure that ongoing procedural improvements are effectively documented. 


\section{Responsibilities}

Quality assurance involves actively maintaining high standards at all levels of responsibility. Achieving and maintaining high-quality standards for all data remain fundamental to the integrity of the USGS. Clear delineations of responsibility sometimes become difficult to determine because of varying levels of expertise and duties in an office, combined with numerous types of gaging activities and instruments. Although the WAWSC Director takes responsibility for overseeing the entire WAWSC program, the person having the greatest effect on the quality assurance of the collected data ultimately is the person who collects those data. Co-workers, supervisors, and managers in the WAWSC organization serve as resources for the hydrographer and others who collect data. Teamwork and communication between employees in collecting, analyzing, and reviewing data are critical to effective implementation of the QA Plan.

The organizational structure of the WAWSC is shown in figure 1; the responsibilities of specific WAWSC personnel for ensuring that certain surface-water QA requirements are implemented are described as follows:

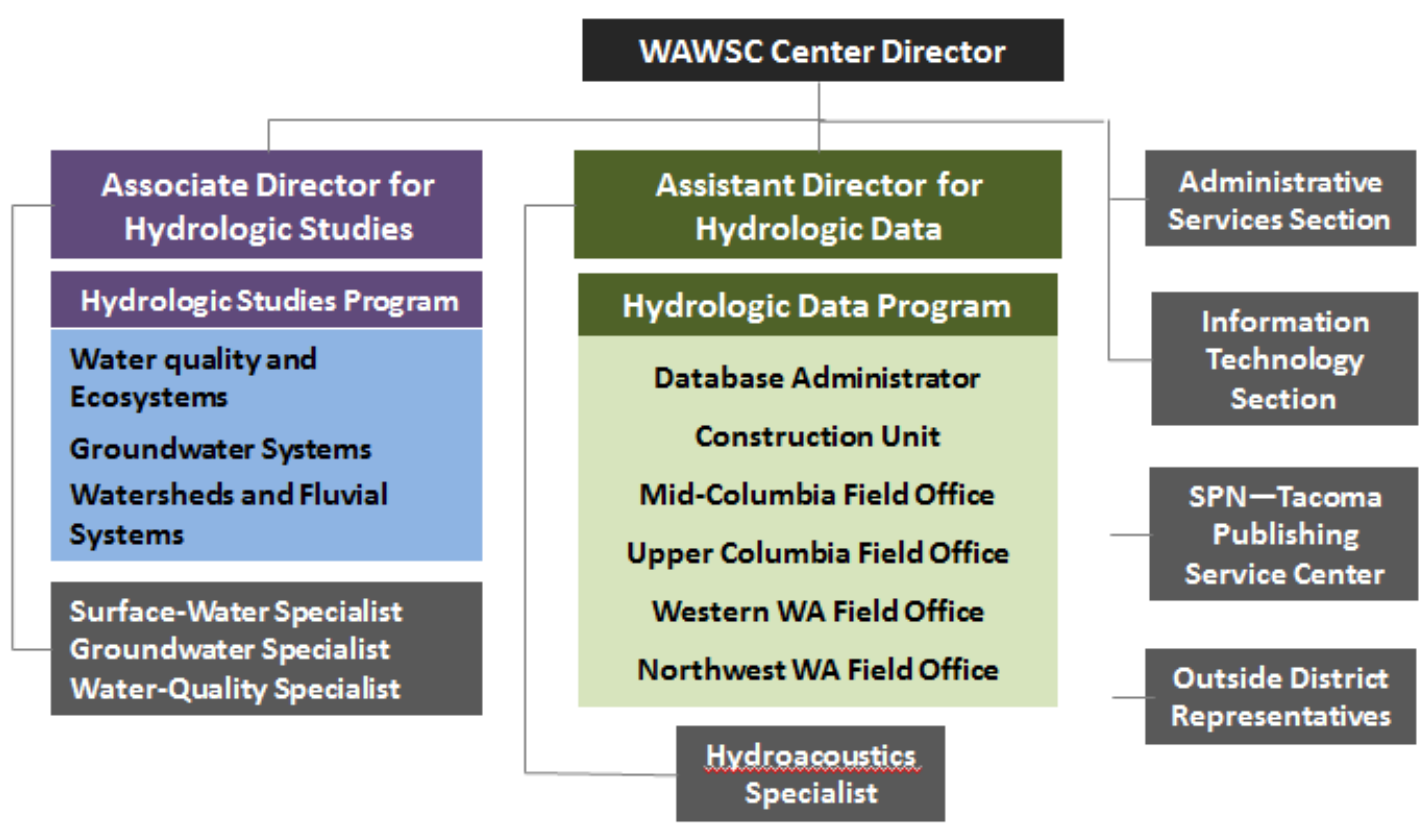

Figure 1. Organization of the U.S. Geological Survey Washington Water Science Center.

\section{Washington Water Science Center Director}

1. Manages and directs the WAWSC program, including all surface-water activities.

2. Ensures that surface-water activities in the WAWSC meet the needs of the Federal Government, Tribes, State and local agencies, and the public.

3. Ensures that all aspects of this QA Plan are understood and followed by WAWSC personnel. This is accomplished by the direct involvement of the WAWSC Director or through clearly stated delegation of this responsibility to other personnel in the WAWSC.

4. Provides final resolution of any conflicts or disputes related to surface-water activities within the WAWSC. 
5. Keeps subordinates briefed on procedural and technical communications from the USGS Water Science Field Team and Water Mission Area.

6. Performs or facilitates periodic reviews of all surface-water activities.

7. Ensures that all publications and other technical communications released by the WAWSC are accurate and in accord with USGS policy.

Washington Water Science Center Assistant Director for Hydrologic Data (Data Chief)

1. Advises WAWSC Director on all matters related to surface-water networks and data-collection in the WAWSC.

2. Implements the WAWSC QA Plan in the Hydrologic Data Program and coordinates qualityassurance activities between field offices and other units in the Data Program and WAWSC.

3. Ensures that surface-water activities within the Data Program satisfactorily address qualityassurance issues.

4. With the WAWSC Director, coordinates surface-water quality-assurance issues with the WAWSC, the Water Science Field Team, and Water Mission Area staff specialists.

Washington Water Science Center Associate Director for Hydrologic Studies (Studies Chief)

1. Reviews ongoing investigations within the Hydrologic Studies Program that have surface-water data requirements and ensures that this QA Plan, including appropriate data archiving, is being followed.

2. Resolves any project-specific surface-water quality-assurance issues with the Surface-Water Specialist.

3. Advises the WAWSC Director and Data Chief on current surface-water projects within the WAWSC.

Washington Water Science Center Surface-Water Database Administrator

1. Ensures that data disseminated from the National Water Information System (NWIS) have been quality-assured before release to the public.

2. Makes recommendations to the WAWSC Data Chief for improvement of surface-water qualityassurance procedures regarding NWIS and real-time surface-water data.

\section{Washington Water Science Center Surface-Water Specialist}

1. Advises WAWSC Director, Data Chief, and Studies Chief of current surface-water quality-assurance policy and procedures and has responsibility for developing and updating this QA Plan.

2. Keeps abreast of current Water Mission Area policies, procedures, and practices regarding the quality assurance of surface-water data.

3. Reviews and certifies International Gaging Station records, project surface-water records, and all WAWSC indirect measurements; participates in the WAWSC QA review of network station records.

4. Reviews project proposals involving surface-water data collection and analysis for adherence to this QA Plan.

5. Reviews surface-water elements of WAWSC interpretive and data-collection projects and serves as advisor to WAWSC staff on technical matters concerning surface-water hydrology and hydraulics. 
6. Reviews surface-water reports produced by the WAWSC and ensures that proper adherence to this QA Plan has been maintained in data collection and analysis.

7. Makes recommendations to WAWSC Director, Studies Chief, and Data Chief for improvements in WAWSC surface-water quality-assurance programs and procedures.

8. Develops and (or) arranges training in surface-water techniques and principles for WAWSC staff.

\section{Washington Water Science Center Hydroacoustic Specialist}

1. Advises the WAWSC Data Chief, Surface-Water Specialist, and Project Chiefs about all aspects of the use of hydroacoustic instruments.

2. Updates users of hydroacoustic instruments about new policies and recommended procedures pertaining to the use of those instruments.

3. Updates users of hydroacoustic instruments about instrument software and hardware upgrades.

4. Helps users of hydroacoustic instruments to troubleshoot malfunctions and take corrective actions.

5. Reviews data, procedures, methods, and documentation regarding hydroacoustics.

6. Updates hydroacoustic quality-assurance documents that include archival of instrument-specific maintenance and repairs, and maintains the instrument log.

7. Advises the Data Chief on hydroacoustic training and coordinates internal gatherings to watch Office of Surface Water hydroacoustics webinars and podcasts.

8. Ensures that trained Center personnel are qualified users of hydroacoustic instruments.

\section{Field Office Chiefs}

1. Ensure that field office personnel follow this QA Plan.

2. In consultation with the Data Chief, Surface-Water Specialist, and Hydroacoustics Specialist, implement procedures to improve field office surface-water data-collection methods when needed.

3. Coordinate surface-water quality-assurance activities between field office employees and other staff within the Data Section and other units in the WAWSC.

4. Provide input to Data Chief on surface-water quality-assurance procedures used by field office personnel.

\section{Project Chiefs}

1. Ensure that project personnel follow this QA Plan.

2. In consultation with the Surface-Water Specialist, implement procedures to improve surfacewater data-collection methods when needed.

3. Coordinate surface-water quality-assurance activities between project staff and personnel in other units in the WAWSC.

4. With the Surface-Water Specialist, develop project-specific quality-assurance plans for surfacewater activities not addressed in this plan.

\section{Field Personnel}

1. Follow the guidelines and procedures outlined in this QA Plan.

2. Notify supervisors of any issues that make it difficult or impossible to follow this QA Plan while performing any of their surface-water activities, and recommend corrections.

3. Regularly review real-time data to detect and correct problems with the gage-height record. 


\section{Collection of Surface-Water Data}

Planning and resource management require reliable surface-water data because many daily activities of society, including industry, agriculture, energy production, waste disposal, habitat protection, and recreation, link closely to streamflow and water availability. The collection of stage and discharge data is a primary component of operating streamflow-gaging stations (referred to as "gaging stations" hereinafter) and completing other water-resource studies done by the USGS in the WAWSC.

Most gaging stations operate with the objective of obtaining a continuous record of stage and discharge at the selected site (Carter and Davidian, 1968). A system of instruments that senses and records water-surface elevation in the stream provides a continuous record of stage. Hydrographers periodically make discharge measurements to define or verify the stage-discharge relation and to define the time and magnitude of variations in that relation.

In the WAWSC, all personnel follow established USGS guidelines on the collection of stage and discharge data. Several USGS publications (such as Water-Supply Paper 2175 [Rantz and others, 1982]) that have been more recently supplemented with two Techniques and Methods reports (Sauer and Turnipseed, 2010; Turnipseed and Sauer, 2010) provide detail on some of these guidelines (appendix A). Guidelines are also provided in USGS Office of Surface Water (OSW) technical memorandums (appendix A).

At numerous sites in Washington, simple stage-discharge relations cannot be developed because of the effect of tides or backwater from downstream dams. In those situations, discharge is computed using relations for stage-area and index velocity-average velocity or with a stage- discharge relation that includes slope as a parameter.

Unique conditions and the development of new technology sometimes involve the collection of surface-water data with alternative equipment, some of which have not been fully accepted by USGS. To demonstrate the quality of surface-water data collected with alternative equipment, field offices must thoroughly document procedures and observations.

In other cases, the WAWSC may cooperate or contract work with another agency that uses alternative equipment, such as Swoffer current meters. Quality-assurance programs between alternative meters and USGS-approved meters will be developed between the USGS and the other agency or contractor to assess whether the alternative meter can be used regularly. Such a program would entail testing both types of meters under controlled and field conditions with an array of stream discharges to validate or invalidate use of the alternative meter. Additionally, the other agency or contractor must provide the WAWSC with the procedures they use for ensuring proper calibration of their current meters.

The WAWSC constantly seeks to improve current standards of equipment, and sometimes purchases Electronic Data Loggers (EDLs), Data Collection Platforms (DCPs), pressure transducers, or other equipment. Before alternative equipment is permanently installed, the WAWSC tests the equipment against standards tested and approved by the USGS Hydrologic Instrumentation Facility (HIF) to meet USGS guidelines. The Field Office or Project Chief ensures that WAWSC personnel correctly use alternative equipment and comprehensively document the use of the equipment.

\section{Gage Installation and Maintenance}

Critical activities for ensuring quality in streamflow-data collection and analysis include proper installation and maintenance of gaging stations. Effective site selection, correct design and construction, and regular maintenance of a gaging station are of paramount importance to the efficient collection of accurate streamflow data. 
Site selection for a gaging station depends on several criteria, including the purpose of the gaging station, hydraulic conditions, and access. Criteria that describe the ideal gaging-station site (Rantz and others, 1982, p. 5) include unchanging natural controls that promote a stable stage-discharge relation, a satisfactory reach for measuring discharge throughout the expected range of stage, and a means for efficient access to the gaging station and measuring location. Other aspects of hydraulic controls considered by WAWSC personnel when planning gage-shelter installations include physical features such as rock riffles, overflow dams, and channel characteristics (Kennedy, 1984, p. 2).

The Field Office Chief or Project Chief, in conjunction with input from field personnel familiar with the area, the construction crew, and the Data Chief and (or) Surface-Water Specialist, selects sites for new gaging stations and oversees the construction. Factors considered in site selection include (1) purpose of the gaging station, (2) hydraulic and hydrologic considerations, and (3) cost and accessibility. Selecting a new site includes several steps, such as consulting with the cooperating agency, checking terrain and drainage area on a topographic map, field reconnaissance, and a search for data from previous sites on the selected or nearby streams. The Field Office or Project Chief ensures that agreements with property owners are properly documented and that all necessary permits have been obtained. In Washington, permits are required from the landowner (private, local, State, or Federal agency) and the Washington Department of Fish and Wildlife (Hydraulic Project Approval). Other permits also may be required at some sites. The Field Office Chief or Project Chief approves the site design, in conjunction with input from the hydrographer who will be servicing the site, the construction crew, and the Data Chief and (or) Surface-Water Specialist. The Field Office Chief or Project Chief approves the final gaging station product.

A program of careful inspection and maintenance of gaging stations and shelters promotes the collection of reliable and accurate data. Allowing the equipment and structures to fall into disrepair may result in unreliable data and unsafe conditions. WAWSC field personnel do basic maintenance of gaging stations on a regular basis. To prevent the buildup of mud or the clogging of intakes, hydrographers flush intakes to stilling wells during each visit (unless weather is below freezing) and de-silt the wells as needed or after a major flood. Other regular maintenance activities by hydrographers include checking all inside and outside staff gages, checking the bubbler rate, removing debris and silt from the pressure transducer, purging the transducer orifice line, checking/maintaining the battery voltage, noting outside high-water marks, and maintaining a log of inspection information in the gage shelter (fig. 2).

The hydrographer ensures that gages and gage shelters are kept in good repair. To ensure these responsibilities are carried out, hydrographers report any deficiencies that they cannot immediately repair to the Field Office Chief. Annual cableway inspections are documented on cableway inspection checklist (appendix B1) by those with the proper training, hard copies are filed with the Field Office Chiefs, and then the Cableway Status Report is updated in Site Information Management System (SIMS). The hydrographer should work with the Field Office or Project Chief to remedy the noted deficiencies or hazards. The hydrographer should never compromise safety for any reason and must accurately document station safety deficiencies to the Field Office or Project Chief. 


\section{GAGING STATION OPERATION AND MAINTENANCE}

- Gage-shelter inspection information is recorded on electronic field forms with the Surface Water Measurement and Inspection (SWAMI) program, or as a backup, use Form 9-275F (appendix B4), to include:

Name of field person or observer

Date of visit and times of readings

Reference gage reading

Auxiliary gages - inside or outside staff gages, tape gage, electronic data logger

(EDL), transducer, or radar readings

Station number and station name

- Check bubbler system at pressure transducer sites

Read and record pressure in nitrogen tank

Check for leaks in system

- Flush intakes and purge orifice lines

Ensure water runs nearly clear from stilling well

For submersible pressure transducers, remove and clean transducer as needed; for non-submersibles, purge orifice line

- Take corrective action if stages indicated by recorder and reference gage differ by more than 0.02 feet

Adjust and note data logger offsets

Adjust and note tape stage indicator

Run levels (later) to resolve reference-gage accuracy issues

Establish temporary reference point for damaged gages

- Check battery voltage, regulator/charger, and solar panel

Replace battery if voltage less than 12.1 volts (use volt meter)

Check solar panel for cracks, bullet holes

- Check data logger; download data with field computer

Maintain computer battery in charged condition

Keep spare battery pack with computer

Keep log of programs for stations in field trip

Keep hard copies of programming sheets in field folder or gage shelter

- Cut grass, brush, and tree limbs around gaging station and lines as needed

- Check cableway, anchors, and cable car, if applicable

Check footings, U-bolts, clamps, cable car for rust, wear

Keep footings clear of brush, soil

Keep extra cable car puller in field vehicle

Inspect cableway system thoroughly once a year

- Make discharge measurement at site as scheduled

Read reference and recorder gage heights before and after measurement and record on form; record logged gage heights

Record location of measuring section, control, and flow conditions

Figure 2. Activities for gaging station operation and maintenance. 


\section{Measurement of Stage}

Many types of available instruments measure the water level, or stage, at gaging stations. Gage types include nonrecording gages (Rantz and others, 1982, p. 24; Sauer and Turnipseed, 2010, p. 13) and recording gages (Rantz and others, 1982, p. 32; Sauer and Turnipseed, 2010, p. 30). Because stage data may be used in various ways, OSW policy requires that field personnel collect surface-water stage records at stream sites with certain procedures and instruments of specified accuracy (OSW Technical Memorandum 93.07). These instruments and procedures provide sufficient accuracy to support computation of discharge from a stage-discharge relation, unless greater accuracy is required.

Gaging stations usually operate to determine daily discharge, instantaneous stage or discharge, or annual extremes in stage and discharge. This includes the goal of collecting stage data at the accuracy of $0.01 \mathrm{ft}$ or 0.2 percent of the effective stage, whichever is less restrictive for the stage being measured (OSW Technical Memorandums 89.08, 93.07 and 96.05; Sauer and Turnipseed, 2010, p. 3). In some cases, however, such accuracy is impossible. For example, in the WAWSC, stage at some large river gaging stations surges as much as $\pm 0.10 \mathrm{ft}$, and at some turbulent mountain streams, hydrographers cannot read staff gages more accurately than $\pm 0.10 \mathrm{ft}$. In these instances, comments in the measurement notes and station analysis alert the data user to such irregularities. In the WAWSC, depending on the size of the stream, these irregularities do not necessarily result in downgrading of the data. For example, at some gaging stations on the Columbia River, stage can vary by several hundredths of a foot, but the difference amounts to less than 5 percent of the flow. OSW Technical Memorandum 93.07 provides an explanation of USGS policy on stage-measurement accuracy as it relates to instrumentation.

The types of instrumentation installed at any specific gage shelter operated by the WAWSC depend on numerous factors including the needs of the cooperating agency, availability of utility lines, terrain (including slope and aspect), configuration of the stream and its banks, and the expected range in stage. Types of continuous water-level recorders operated by personnel in the WAWSC include various manufacturers of Electronic Data Loggers (EDLs) and Data Collection Platforms (DCPs) connected to stage sensors. Sensors used to monitor stage include float and tape assemblages driving shaft encoders, submersible and nonsubmersible pressure transducers, acoustic Doppler velocity meters (ADVMs), and non-contact radar sensors. Instruments used for the manual measurement of stage (reference and auxiliary gages) include steel tapes in conjunction with fixed reference marks, staff gages, wire-weight gages, and electric-tape gages. The Field Office or Project Chief, in consultation with the cooperating agency, the hydrographer to be assigned the station, and the Data Chief and (or) Surface-Water Specialist, determines the type of water-level recorders and sensors to be installed and operated at each gaging station.

Accurate stage measurement requires not only accurate instrumentation but also proper installation and continual monitoring of all system components to ensure that the accuracy does not deteriorate with time (OSW Technical Memorandum 93.07). Hydrographers observe reference and auxiliary gages to ensure that gage-shelter instruments accurately record the water levels of the body of water being investigated. The reference gage should not be confused with a "base gage," which is present at a slope station and is used in conjunction with an auxiliary gage some distance away (Kennedy, 1983, p. 10). The reference gage is a nonrecording gage used to set the recorder. The main purpose of the reference gage is to furnish periodic independent water-surface elevations to monitor the accuracy of the stage recorder and other gages (Kennedy, 1983, p. 10). The stage recorder provides the continuous or near-continuous record of surface-water elevations. For example, at gaging stations with stilling wells, hydrographers usually check the float recorder against the reference gage (commonly either an inside staff gage or electric-tape gage). At a gaging station with a pressure transducer, the transducer (the recording gage) is checked against a wire-weight gage or outside staff gage (the reference gages). In eastern Washington, reference points (for taping down to the water surface) may 
serve as reference gages because outside staff gages would be destroyed regularly by ice in the river. The relation between the reference gage and the recording gage can change as the gage height increases, and hydrographers document these changes. Because of the potential differences, the recording gage should not be adjusted to the reference gage during high flows, except when there is clearly an equipment malfunction that must be remedied. Stage-discharge rating curves should be drawn on the basis of data from the reference gage.

The hydrographer ensures that the instrumentation installed at gaging stations is properly serviced and calibrated by visiting the site and observing any deficiencies. If observed deficiencies are minor, the hydrographer should repair them on the spot using spare parts carried in the field vehicle. If the deficiencies are major, then the hydrographer consults with the construction crew, Field Office Chief, or Project Chief to formulate a plan of corrective action. The nature of the observed deficiencies will dictate which person(s) should be consulted. Individuals who have questions related to the calibration and maintenance of water-level recorders should contact the Field Office or Project Chief.

Secondary methods of data verification remain one of the key elements of quality-assured data. These methods become particularly important with extremes in stage data and data collected with pressure transducers. For gaging stations with stilling wells, maximum and minimum clips on the float tapes record the maximum and minimum stage recorded by the tape and float system. High-water marks (HWMs) inside (from ground cork or debris) and outside the well supplement and verify the maximum recorded stage. For gaging stations with pressure transducers or radar sensors, crest-stage gages (CSGs) record the maximum water levels. Field personnel should install CSGs in the same cross section and gage pool that is measured by the transducer.

\section{Collection of Precipitation Data}

The OSW Technical Memorandum 2006.01, revised December 2009, thoroughly describes the collection, quality assurance, and presentation of precipitation data.

Most precipitation gages operated by the WAWSC provide "temporary" data and are maintained only as an aid in operations for the cooperator. Temporary data are not intended for publication, although the data will remain in the National Water Information System (NWIS) database as provisional data for 120 days. "Permanent" precipitation data are published and archived.

Requirements for these data include annual calibration of the gage and archival of station descriptions, calibration forms, and original filed inspection notes. Additionally, permanent sites require annual station analyses. More information is available in OSW Technical Memorandum 006.01.

\section{Gage-Shelter Documents}

WAWSC procedure dictates that hydrographers maintain certain documents in each gage shelter as an on-site record of observations, equipment maintenance, structural maintenance, and other information helpful to field personnel (fig. 3). Some of this documentation is not necessary if the hydrographer is using the AutoFF program described later in this section. If AutoFF is not being used, documents maintained at each gage shelter will include:

- A log of site visits, updated by field personnel during each visit, which describes control conditions and lists gage readings, gage-shelter maintenance, equipment maintenance, and discharge measurements (appendix B2);

- Copies of the most current rating curve and rating table; 
- A copy of the most recent station description, which describes all the gages, reference marks, and measurement locations;

- A copy of the programming sheet for the EDL or DCP;

- Brief instructions on how to access and program the EDL or DCP;

- Corrections to determine the maximum and minimum stage from clip readings;

- A calendar (optional);

- Any important telephone numbers;

- Notes on any special procedures or characteristics at the gaging station;

- A traffic control plan; and

- Job hazard analyses (JHAs) concerning potentially hazardous conditions at the gaging station. At cableway stations, cableway documentation forms (appendix B1), which list the maximum stage at which to measure discharge and the design cableway sag, also should be maintained in the gage shelter. An optional document to include in the gage shelter is a hydrograph of the previous year's daily mean flows or a hydrograph of mean daily flows for the period of record at the gaging station. If the interior of the gage shelter is often damp, all documents should be kept in a sealed plastic bag to protect them from moisture.

The hydrographer assigned to the gaging station ensures that outdated gage documents are replaced. When field personnel visit a gage shelter and identify a need to update one or more of the documents, they should replace documents immediately or make a note to replace them on the next visit. Individuals with questions related to which documents should be kept in a gage shelter, when the documents should be replaced with newer documents, or how existing documents should be maintained, should contact their Field Office or Project Chief.

As of water year 2014, the use of AutoFF has begun in the WAWSC. AutoFF is a utility to retrieve station information automatically. The program extracts information from SWreview, go2, SIMS, SiteVisit, and ADAPS (Automated DAta Processing System) for each station and places it in one location organized by station number and water year. The intent is to allow the hydrographers to have the most current information about WAWSC gages while in the field, assuming they have updated their personal digital assistant (PDA), tablet, or laptop prior to leaving the office. AutoFF is updated nightly. When using AutoFF, the requirement to have all the paperwork in the gage shelter (fig. 3) is no longer needed. However, it is the responsibility of the hydrographer operating the station to ensure that their PDA, field laptop, or tablet is in good working order and that the AutoFF folder is updated properly. Hard copies of the current station description, any safety information, and the gage log also still need to be in the gage shelter. 


\section{FIELD DOCUMENTS}

- Gage-shelter documents

*Maintain a log of gage-inspection information using Form P-19 (appendix B2) or substitute, include

Servicing party and date

Outside gage reading

For stilling well sites, inside staff and tape readings

For transducer sites, N2 tank and regulator pressure, and bubble rate

As appropriate, radar and Electronic Data Logger (EDL) readings

Battery voltage

Measurement information

Where measured

Equipment used

Maximum depth and velocity

Remarks on control, point-of-zero-flow, high-water mark, maximum and minimum clips, etc.

Comments on flushing intakes or cleaning transducer

Copy of EDL or Data Collection Platform programming sheet; basic programming instructions

Special gage notes

Special attention items

Maximum and minimum clip corrections

Telephone contacts

*Copy of most recent station description

Copy of current rating and rating table

List of discharge measurements and preliminary shifts

Pertinent notes, letters regarding gages at site

*Traffic control plan

* Station job hazard analysis

*Minimum required gage-shelter paperwork when using AutoFF.

Figure 3. Gage shelter documents. 


\section{Gage Datum and Levels}

The various gages at a gaging station are set to register the elevation of a water surface above a reference level referred to as the gage datum. The supporting structures of gages - stilling wells, backings, shelters, bridges, and other structures - tend to settle or rise as a result of earth movement, static or dynamic loads, vibration, ice-heaving, or damage by floodwaters and flood-borne ice or debris. Vertical movement of a structure makes the attached gages read too high or too low and, if the errors go undetected, may lead to increased uncertainties in streamflow records. Hydrographers should note that a recent OSW memo (January 29, 2013) requires a 90-day notification period prior to gage datum changes at gaging stations. (See OSW Technical Memorandum 2013.02 for more details.) Hydrographers use differential leveling, a procedure that uses surveying instruments to determine elevation differences between two points, to determine the gage datum and periodically check the gage for vertical movement (Kenney, 2010). Running levels periodically to all benchmarks, reference marks, reference points, and gages at each station reveals if any datum changes have occurred (Rantz and others, 1982, p. 545). Three widely dispersed independent reference marks need to be established at every gage, to minimize the chance that all of the reference marks would be lost during a flood. At sites with pressure transducers, levels are run to the orifice whenever possible.

The WAWSC procedure requires that levels be run periodically at all gages. Field personnel should run levels at newly installed gaging stations when the gages are established and then annually for 3 years until gage stability is established. Generally, levels at established gaging stations should be run once every 3 years, after any major flood, after any type of earth movement in the area, or any time unresolved gage-height discrepancies are present between the various gages at a gaging station. If the reference gage is moved or changed at an established gaging station, then annual levels are again required for 3 years, until gage stability is established. See the decision tree by Kenney (2010, fig. 14) to determine if levels are needed.

Kenney (2010) described field and documentation methods used to run levels that include details on procedures pertaining to circuit closure, instrument reset, and repeated use of turning points. Field personnel maintain the level instruments in proper adjustment by running a fixed-scale test and (or) a peg test (Kenney, 2010, p. 6-7). The WAWSC requires a two-peg test weekly or before each levels trip. Personnel document these tests in the Station Levels application. Station Levels is an application used to calculate and record levels information when running levels at a station. The application can run on a PDA, laptop, or tablet, and the output data are in a HydroML-formatted file. More information is available on the Station Levels internal Web site. Leveling rods are affected by expansion and contraction due to temperature changes, and the effect varies with the material composition of the rod. Prior to running levels, the leveling rod scale temperature needs to be measured to determine whether corrections are needed (Kenney, 2010, p. 11-13). Non-contact infrared thermistors provide the best method to measure the temperature of the leveling rod, but in situations when these thermistors are not available, air temperature may be used. Kenney (2010) provides the expansion or contraction equations and indicates how backsights and foresights can be corrected, or the temperature can be entered into the Station Levels program for automatic evaluation and automated backsight or foresight corrections. After running levels to the reference marks, and auxiliary and reference gages, Station Levels will distribute errors and compute the closure and the allowable closure. 
The hydrographer checks for satisfactory closure before leaving the site. If the closure error is greater than the allowable closure, a complete level circuit has to be run again. Hydrographers will reset gages to agree with levels when levels show a difference of $0.015 \mathrm{ft}$ or more of vertical change. When gages are reset, field personnel will document what they did on in the Station Levels program or on field level notes. For other checks when less accuracy is required, other types of levels, such as a laser level, are acceptable. The elevation of the outside water surface always should be determined when levels are run.

The hydrographer ensures that all field level notes are checked and that levels are run at the appropriate frequency. The hydrographer enters the level information within 2 weeks after the levels are completed into Site Levels Archiving and Processing (SLAP), a Web-based tool that combines digital data from Station Levels, manually recorded data, and supporting documents to create a historical levels summary. SLAP data are available through SIMS. More information on SLAP is available on the internal Web site. The historical summary should include changes in elevation of reference marks and the orifice, and corrections to be applied to the reference and auxiliary gages. The Field Office Chief ensures that levels are run correctly and that all Station Levels files and level notes are completed correctly and entered into SLAP.

\section{Site Documentation}

Site documentation requires thorough qualitative and quantitative information describing each gaging station. This documentation, in the form of a station description and photographs, provides a permanent record of site characteristics, structures, equipment, instrumentation, altitudes, location, and changes in conditions at each site. These documents also provide a history of past floods, nearby construction, or any unusual occurrences at the site.

\section{Station Descriptions}

A station description outlining basic gage information becomes part of the permanent record for each gaging station. The WAWSC procedure dictates that the station description for a new gage is written at the time the first-year records are computed and they are entered into SIMS. The hydrographer assigned to service the gaging station ensures that the station description is prepared correctly and in a timely manner. Hydrographers should obtain assistance from the Field Office Chief if they have a question on preparing and completing station descriptions. The hydrographer reviews station descriptions every year and updates them if necessary. The Field Office Chief reviews all station descriptions to ensure that they are updated and complete.

Station descriptions outline specific types of information in a consistent format (Kennedy, 1983, p. 2). The station description includes information such as location of the gaging station, date of establishment, drainage area upstream of the site, a description of the gages, history of activities at the gaging station, reference and benchmarks, channel and control characters, floods, point-of-zero-flow (PZF) data, site maps, and road logs to the site. Other items hydrographers should include are details on discharge measurement locations and types of instruments needed for various flow conditions, extreme stage and discharge, regulations and diversions, cooperative agencies, local observers, and other sitespecific information such as a SITE HAZARDS element in SIMS (site-specific safety issues and medical facilities) (Kennedy, 1983, p. 3-5).

Drainage areas determined using geographic information system methods should be checked against the original drainage-area maps for consistency. The accuracy of drainage areas determined from digital elevation models (DEMs) likely will improve as the resolution of DEMs increases. StreamStats, an online interactive map program, provides a simple tool to compute drainage areas consistently (http://water.usgs.gov/osw/streamstats/Washington.html). 
Hydrographers maintain paper copies of the station description in the station folder and field folder (unless they are using AutoFF) and at the site, as well as electronic copies in SIMS. For new sites, hydrographers obtain latitude and longitude at the sensor location in the field using a Global Positioning System (GPS). Historical information is obtained from various sources such as annual reports, investigative or open-file reports, or USGS and other-agency files. The surface-water database administrator for the WAWSC assigns the station number.

OSW Technical Memorandum 2014.03 requires gage operation limits to be input into ADAPS as relevant thresholds for the stage sensors. These limits include the very high (VHI) and very low (VLO) thresholds. (See OSW Technical Memorandum 2014.03 for more details on how to determine these thresholds.) These thresholds are to be included in the station descriptions.

\section{Photographs}

Field personnel photograph gage shelters, station controls, channel conditions, reference marks, flood damage, indirect-measurement sites, vandalism, and other important conditions to document activity and conditions at the gaging station. Field personnel should carry digital cameras or cell phones in their field vehicles to take photographs as needed. The WAWSC office maintains a few cameras that can be checked out for more extensive photographic needs. Digital photographs are archived in the appropriate folder on the field office server (appendixes $\mathrm{C}$ and $\mathrm{E}$ ).

\section{Direct Discharge Measurements}

Hydrographers make direct measurements of discharge using any one of numerous methods approved by USGS. Common methods include the vertical axis current-meter method, FlowTracker ${ }^{\circledR}$ Acoustic Doppler Velocimeter (ADV) and the acoustic Doppler current profiler (ADCP). In the sectionby-section measurement, the sum of the products of the subsection areas of the stream cross section and their respective average velocities determines the discharge. Turnipseed and Sauer (2010) describe procedures used for section-by-section measurements.

When hydrographers make measurements of stream discharge, they attempt to minimize errors. Turnipseed and Sauer (2010) and Sauer and Meyer (1992) identify sources of errors, which include random depth errors associated with soft, uneven, or mobile streambeds and uncertainties in mean velocity associated with vertical-velocity distribution errors and pulsation errors. Velocity distribution errors also include systematic errors, or bias, associated with improperly calibrated equipment or the improper use of such equipment.

To reduce systematic errors in direct-discharge measurements, Field Office Chiefs rotate most field trips every 3 years, or include informal check-measurement programs on all field trips. Because of complex, varied instrumentation and remote station locations, some field trips tend to be matched to expertise and physical capabilities, and thus rarely are rotated.

The WAWSC practices related to the measurement of discharge by use of the section-by-section method, in accordance with USGS policies, include topics such as depth and section-width criteria, number and distribution of measurement subsections, computation of mean gage height or weighted mean gage height, check measurements, and corrections for storage (fig. 4). 


\section{GUIDELINES FOR DIRECT MEASUREMENT OF DISCHARGE USING A FLOWTRACKER ${ }^{\circledR}$ OR MECHANICAL CURRENT METER}

- Ideal cross-section selection criteria

A nearly uniform bottom across section

Average velocity greater than $0.5 \mathrm{ft} / \mathrm{s}$, depth greater than $0.5 \mathrm{ft}$

Straight channel whenever possible to avoid angles

Uniform flow, free of eddies, slack water, and excessive turbulence

Cross section is close to gage to avoid storage/inflow adjustment

- Meter selection criteria

Depth of water

If greater than $1.5 \mathrm{ft}$, select Price AA meter

Use low-flow AA meter for cross sections with average velocity of less than $1 \mathrm{ft} / \mathrm{s}$

If less than $1.5 \mathrm{ft}$, select pygmy meter or FlowTracker ${ }^{\circledR}$

- Current-meter quality assurance/maintenance

Perform spin test before each trip and log, or perform each day

For Price AA meter, 2 minutes is acceptable, 4 minutes is ideal

For Price pygmy meter, 45 seconds is acceptable, 1.5 minutes is ideal

Check meter and repair or replace bent cups and worn pivots

Clean and oil meter daily, or after each measurement in sediment-laden water

Complete the built-in Quality Control Test with each FlowTracker ${ }^{\mathbb{B}}$ measurement

A BeamCheck is required for the FlowTracker ${ }^{\circledR}$ when (1) a new instrument is first received, (2) if damage may have occurred, (3) a firmware upgrade or repair was made, and (4) after any

Quality Control Test failures.

- Measurement notes include

Date, party, meter type, suspension, and meter number

Name of stream and gaging station number, or location for miscellaneous measurement

Stage readings and times before, during, and after measurement

Time measurement started and ended, with intermediate times

Bank of stream that measurement was started from

Control and flow conditions

Other pertinent information regarding conditions

- Number of measurement stations in a cross section

Ideally about $25-30$ stations

Target for 5 percent of flow in each station (but no more than 10 percent)

Use fewer stations for rapidly changing stage, floods with much debris, or narrow channels

- Stopwatch

Periodically test with regular watch or another stopwatch

Allow 40-70 seconds for each vertical measurement ( $1 / 2$ counts $O K$ in rapidly changing stagerecord as $1 / 2$ counts)

- Check measurements

Consider making a second measurement if first measurement is more than percent quality rating of the measurement from current rating or current shift. Depending on factors such as the quality of the measurement, the stability of the rating, the number of measurements made at the site, and stage, hydrographers should use their judgment to decide if another check measurement is needed.

Change meter or Acoustic Doppler Velocimeter or use an acoustic Doppler current profiler

Use different stationing, or change cross sections

- Compute the final discharge before leaving the site.

Figure 4. Guidelines for direct measurement of discharge using a FlowTracker ${ }^{\circledR}$ or mechanical current meter. 


\section{Depth Criteria for Meter Selection and Velocity-Measurement Method}

WAWSC personnel select the type of current meter to be used for each discharge measurement on the basis of criteria presented by Turnipseed and Sauer (2010) and in OSW Technical Memorandum 85.07. In most cases, the available current meters are a Price Type AA, Price Pygmy, and the FlowTracker ${ }^{\circledR}$. The ADCPs are discussed in the section “Acoustic Doppler Current Profilers.” Personnel should use current meters with caution when a measurement must be made in conditions outside the ranges of the method presented by Turnipseed and Sauer (2010) or in OSW Technical Memorandum 85.07, and they should downgrade the measurement accuracy accordingly.

Mean velocity for a vertical section generally is determined as the velocity at 60 percent of the depth (0.6 depth), or more accurately the average of the velocities taken at 20 percent ( 0.2 depth) and 80 percent (0.8 depth) of the depth (Sauer and Meyer, 1992). If a non-standard logarithmic velocity profile is discovered when using the 0.2- and 0.8-depth method, the 0.2-, 0.6-, 0.8-depth method should be used (Turnipseed and Sauer, 2010, p. 23; Rantz and others, 1982, p. 135). Meters will under-register velocities, however, when too close to the water surface or streambed. The AA meter should not be within $0.5 \mathrm{ft}$ of one of these boundaries, the Pygmy meter should not be within $0.3 \mathrm{ft}$ of a boundary, and the FlowTracker ${ }^{\circledR}$ should not be within $0.2 \mathrm{ft}$ of a boundary. Depth and velocity-measurement method criteria, as outlined by Turnipseed and Sauer (2010), are shown in table 1.

Table 1. Current meter and velocity-measurement method for ranges of depth.

[ADV, acoustic Doppler velocimeter]

\begin{tabular}{|l|l|l|}
\hline \multicolumn{1}{|c|}{$\begin{array}{c}\text { Depth } \\
\text { (feet) }\end{array}$} & \multicolumn{1}{|c|}{ Current meter } & \multicolumn{1}{|c|}{ Velocity-measurement method } \\
\hline 2.5 and greater & Price Type AA & 0.2 and 0.8 \\
\hline $1.5-2.5$ & Price Type AA & 0.6 \\
\hline $0.3-1.5$ & Price Pygmy & 0.6 \\
\hline 1.5 and greater & Price Pygmy & 0.2 and 0.8 \\
\hline $0.3-1.5$ & ADV & 0.6 \\
\hline 1.5 and greater & ADV & 0.2 and 0.8 \\
\hline
\end{tabular}

Frequently, stream conditions fit guidelines between those for each meter. In these instances, the meter most suited for most of the channel flow should be used. For example, if the cross section varies from depths of $0.7 \mathrm{ft}$ for $10 \mathrm{ft}$ of the cross section, then slowly increases to $2.5 \mathrm{ft}$ for $30 \mathrm{ft}$ of cross section, then gradually decreases to $1 \mathrm{ft}$ of depth over $10 \mathrm{ft}$, between the two mechanical meters, a Price AA meter probably is the best meter to use because most of the flow likely will be in the deeper part of the cross section. The hydrographer should recognize, however, that there will be some greater error in those parts of the measurement where the water is shallower than $1.5 \mathrm{ft}$. Ideally, a pygmy meter would be used for the parts of the cross section shallower than $1.5 \mathrm{ft}$ and a Price AA meter would be used for areas deeper than $1.5 \mathrm{ft}$; however, this generally is not practical and probably is not worth the effort for the slight gain in measurement accuracy. It is recommended that a change of meters is not made during a measurement in response to the occurrence of two or more subsections in a single measurement cross section that exceed the stated ranges of depth and velocity. In cases where two channels are present, one deep and one shallow, changing meters becomes more practical and reasonable.

Often at the edges of a channel, the channel is too shallow for the weight and meter that was deployed based on the characteristics of the main flow of the river. In the shallow water, with the weight on the bottom, the meter may still be above the 0.6 depth in the vertical profile and the measured velocity will be greater than the average for the vertical profile (assuming standard vertical velocity profile). In these situations, a WOB (Weight on Bottom) coefficient should be used, whereby the 
measured velocity of the vertical is multiplied by the Weight On Bottom coefficient (table 2) to adjust the measured velocity to the mean velocity of the vertical. If this method is applied to many verticals that represent a larger percentage of the flow, the quality of the measurement may need to be downgraded.

Table 2. Weight on Bottom (WOB) coefficient to adjust measured velocity of a vertical to mean velocity for indicated water depth, and corresponding position of the current meter above the sounding weight.

[typical weights for the position of the meter on the hanger bar are shown above the meter position columns]

\begin{tabular}{|c|c|c|c|c|c|}
\hline \multicolumn{2}{|c|}{$\begin{array}{l}15 \mathrm{C} \\
30 \mathrm{C}\end{array}$} & $\begin{array}{l}50 \mathrm{C} \\
75 \mathrm{C}\end{array}$ & $50 \mathrm{C}$ & $\begin{array}{l}75 \mathrm{C} \\
100 \mathrm{C} \\
150 \mathrm{C}\end{array}$ & $\begin{array}{l}100 \mathrm{C} \\
150 \mathrm{C}\end{array}$ \\
\hline \multirow{2}{*}{$\begin{array}{l}\text { Water } \\
\text { Depth }\end{array}$} & \multicolumn{5}{|c|}{ Position of Meter above the Bottom of Weight, in feet } \\
\hline & 0.5 & 0.6 & 0.9 & 1.0 & 1.5 \\
\hline 0.5 & 0.86 & & & & \\
\hline 0.6 & 0.87 & 0.86 & & & \\
\hline 0.7 & $\begin{array}{ll}0.88 \\
\end{array}$ & 0.87 & & & \\
\hline 0.8 & 0.90 & 0.88 & & & \\
\hline 0.9 & 0.92 & 0.89 & 0.86 & & \\
\hline 1.0 & 0.94 & 0.90 & 0.86 & 0.86 & \\
\hline 1.1 & 0.96 & 0.92 & 0.87 & 0.86 & \\
\hline 1.2 & 0.97 & 0.94 & 0.88 & 0.87 & \\
\hline 1.3 & 1.00 & 0.95 & 0.89 & 0.87 & \\
\hline 1.4 & & 0.97 & 0.89 & 0.88 & \\
\hline 1.5 & & 1.00 & 0.90 & 0.89 & 0.86 \\
\hline 1.6 & & & 0.91 & 0.90 & 0.86 \\
\hline 1.7 & & & 0.93 & 0.91 & 0.86 \\
\hline 1.8 & & & 0.94 & 0.92 & 0.87 \\
\hline 1.9 & & & 0.95 & 0.93 & 0.87 \\
\hline 2.0 & & & 0.96 & 0.94 & 0.88 \\
\hline 2.1 & & & 0.97 & 0.95 & 0.88 \\
\hline 2.2 & & & 1.00 & 0.96 & 0.89 \\
\hline 2.3 & & & & 0.96 & 0.89 \\
\hline 2.4 & & & & 0.97 & 0.90 \\
\hline 2.5 & & & & 1.00 & 0.90 \\
\hline 2.6 & & & & & 0.91 \\
\hline 2.7 & & & & & 0.92 \\
\hline 2.8 & & & & & 0.92 \\
\hline 2.9 & & & & & 0.93 \\
\hline 3.0 & & & & & 0.94 \\
\hline 3.1 & & & & & 0.94 \\
\hline 3.2 & & & & & 0.95 \\
\hline 3.3 & & & & & 0.96 \\
\hline 3.4 & & & & & 0.96 \\
\hline 3.5 & & & & & 0.97 \\
\hline 3.6 & & & & & 0.97 \\
\hline 3.7 & & & & & 0.98 \\
\hline 3.8 & & & & & 1.00 \\
\hline
\end{tabular}

Note: Values are computed from the standard vertical-velocity curve (Rantz, S.E., 1982, Measurement and Computation of Streamflow: Volume 1. Measurement of Stage and Discharge: U.S. Geological Survey Water-Supply Paper 2175, Table 2).

Computed by M.C. Mastin 3/21/2014 Approved by T. A. Kenney 5/9/2014

Checked by K.R. Linn 5/7/2014 
FlowTrackers ${ }^{\circledR}$ use the Doppler method to track the velocity of particles in a sample of water located about 4 in. away from the transducer. A lack of particles, too many air bubbles, or large particles can cause erroneous values of velocity. Velocity readings also can be affected when the sample volume is located too close to a boundary such as the side of the channel or large rocks. Hydrographers should try to locate the sample volume at least $2 \mathrm{in}$. away from boundary objects. The FlowTracker ${ }^{\circledR}$ software has quality-assurance data such as the number of "spikes" in the data, sound-to-noise ratios, and boundary flags to evaluate the quality of the data as well as filters to eliminate spikes and signal adjustments for boundary conditions.

Personnel who have questions concerning the appropriate procedures for making stage and discharge measurements should address their questions to more experienced hydrographers, the Field Office Chief, or the Project Chief.

\section{Criteria for Sounding-Weight Selection}

When a discharge measurement must be made from a bridge, cableway, or boat, hydrographers must consider depth and velocity in selecting the correct weight to use. A general rule of thumb is to use a weight (in pounds) at least as heavy as the product of the fastest velocity (in feet per second) and deepest depth (in feet) in the cross section (Rantz and others, 1982, p. 146-147). However, heavier weights may need to be used in shallow, fast streams. If the weight is insufficient, the stream will drag the meter and weight assembly downstream and an air and wet-line correction for depth may need to be used (Rantz and others, 1982, p. 159-168). In the past, a set of coefficients to be multiplied by the measured velocity to compute an adjusted velocity was sometime used when a 100C or $75 \mathrm{C}$ weights were suspended from the 0.55 (or 0.6 ) hole on the hanging bar. There is no known documentation of these coefficients and they should not be used. If the conditions are such (high velocities, shallow depths) that a $75 \mathrm{C}$ or $100 \mathrm{C}$ weight placed at a lower than recommended setting on the hanger bar will result in a more accurate measurement, then the weight may be lowered, but the measurement should be downgraded accordingly, and the velocities should not be adjusted with a coefficient.

\section{Number of Measurement Stations}

The spacing of observation stations or "verticals" in the measurement section can affect the accuracy of the measurement (Turnipseed and Sauer, 2010, p. 9; Rantz and others, 1982, p. 179). USGS criteria state that hydrographers observe depth and velocity at 25-30 verticals. Under the worst conditions, the discharge computed for each vertical should not exceed 10 percent of the total discharge and ideally should not exceed more than 5 percent (Rantz and others, 1982, p. 140). Exceptions to this policy prevail in circumstances where accuracy would be sacrificed if this number of verticals were maintained, such as for measurements during rapidly changing stage (Rantz and others, 1982, p. 174). Hydrographers sometimes use fewer verticals than are ideal for narrow streams (about $12 \mathrm{ft}$ wide when an AA meter is used and about $5 \mathrm{ft}$ wide when a pygmy meter is used). Because measurement of discharge is essentially a sampling process, the accuracy of sampling results often decreases markedly when the number of samples is less than about 25 .

\section{Computation of Mean Gage Height}

WAWSC personnel use procedures presented in Turnipseed and Sauer (2010, p. 39) and Rantz and others (1982, p. 170) for computing mean gage height during a discharge measurement when the change in stage during the measurement is more than $0.10 \mathrm{ft}$. Methods used to determine the mean gage height involve discharge-weighting and time-weighting the stage readings during the measurement; a weighted mean gage height is the average of a time-weighted mean gage height and a discharge- 
weighted mean gage height. Mean gage height is used when plotting a discharge measurement on a stage-discharge rating curve. A SW Form, "Mean Gage-Height Calculation," is available on the internal Hydrologic Data Program internal web page as a Microsoft Excel ${ }^{\circledR}$ spreadsheet to facilitate the calculation of mean gage height.

\section{Check Measurements}

A second discharge measurement is made for the purpose of checking the first discharge measurement when the first measurement differs from the current stage-discharge relation (base rating or shifted rating in effect) by more than the percent quality rating of the measurement; this criterion applies for sites with stable ratings and for channel-control conditions (medium to high flows) at all sites. Because of the shifting streambed of most streams in Washington, large shifts from the current stage-discharge relation commonly are found under section control conditions, many times more than the percent quality rating of the measurement. For section-control conditions, a check measurement should be made whenever the indicated shift is beyond the historical range of shifts from the current rating at that stage, or when the indicated shift is near the edge of the historical range in shifts and there is no clear reason for the change in shift (for example, visible obstruction downstream or recent high flows).

When making a check measurement, hydrographers change or check as much of the instrumentation and conditions as possible. These changes and checks include using a different meter or instrument, changing stopwatches or checking the stopwatch with a regular timepiece, selecting different number or location of vertical stations in the cross section, or selecting a new cross section altogether (Rantz and others, 1982, p. 346). In cases where the second measurement verifies neither the original rating nor shift nor the first measurement, a third measurement might be made and the closest two out of three might be used.

\section{Corrections for Storage}

Turnipseed and Sauer (2010, p. 43) and OSW Technical Memorandum 92.09 discuss corrections for storage applied to measured discharges for the purpose of defining stage-discharge relations. These corrections involve an adjustment to the measured discharge that is based on the channel surface area and average rate of change in stage in the reach between the gage and point of measurement. Storage corrections generally apply only if the discharge measurement is made a significant distance from the gaging-station location.

\section{Field Notes}

A necessary component of surface-water data collection and analysis includes thorough documentation of field observations and data-collection activities. To ensure that clear, thorough, and systematic notations are made during field observations, field personnel record discharge measurements on their PDA, laptop, or tablet using Surface Water Measurement and Inspection (SWAMI) field computing software. When using Aquacalc ${ }^{\circledR}$, FlowTracker ${ }^{\circledR}$, or WinRiver ${ }^{\circledR}$ software to make measurements, the output files will be imported into SWAMI. Standard USGS discharge-measurement notes only should be used when there is a failure of SWAMI, Aquacalc ${ }^{\circledR}$, or FlowTracker ${ }^{\circledR}$. Field notes are considered original legal documents, and, thus, hydrographers should not erase original observations, once written on the note sheet. They should make corrections to original data by crossing out the value, and then writing in the correct value. Some examples of original data on a dischargemeasurement note sheet include gage readings, depths, measurement stations, current-meter counts, and time notations. Hydrographers can erase derived or computed data, such as computed widths, velocities, 
section and total discharges, and mean gage height. Corrections to SWAMI, FlowTracker ${ }^{\circledR}$, and WinRiver files should be shown on the output file along with the reason for the change and initials of the person making the change.

Discharge measurements made during field site visits will be calculated on site after the measurement is made (OSW Technical Memorandum 2012.01). This allows check measurements to be made without having to make another station visit. During floods or other emergency situations, hydrographers should calculate discharge measurements as soon as possible and phone results into the office for informational purposes. This is particularly important during major floods so that discharges the WAWSC presents to the public and the media indicate the most recent conditions.

Information that should be documented by field personnel in SWAMI or on the measurement note sheet includes, at minimum, the initials and last name of all field-party members, date, times associated with gage readings and other observations, station name and number, control and channel conditions, reference and auxiliary gage readings, readings from the EDL or DCP, condition of the battery and nitrogen tank (if applicable), type of instrument used for any discharge measurements, any observed HWMs and (or) maximum and minimum clip readings, crest-stage gage readings, PZF estimates, and any other pertinent information regarding unusual gage or streamflow conditions. The Point of zero flow should be collected at wadable streams with section controls whenever feasible and included in the measurement notes. Mathematics for maximums and minimums from clip readings, PZF estimates, reference-point elevations, and similar calculations should be shown on the measurement note sheet.

If SWAMI or the Station Levels program is not available for whatever reason or it does not have the proper fields to record miscellaneous or unusual information, hydrographers may use paper forms such as those provided in the appendixes of this report as long as the necessary information is included (fig. 5). All miscellaneous notes include, at a minimum, station number and name, initials and last name of field-party members, date, time associated with observations, purpose of the site visit, and pertinent gage-height readings or other information. Use Form 9-275 F (appendix B4) for discharge measurement notes, Form 9-275 D (appendix B5) for miscellaneous notes, Form T-9335 for crest-stage gage notes (appendix B6), Form T-9334 for snow survey notes (appendix B7), and the peg test and station levels notes form for peg test and level notes (appendix B3). Various pertinent station and conditions information, readings, observations, and calculations are required in completing these notes (fig. 5).

The degree of review and checking of field note sheets depends on the experience and demonstrated performance of the hydrographer. For new hydrographers, fellow hydrographers check every measurement or field note immediately after the site visit to ensure that all required information and observations are made and noted correctly, and that discharge measurements are being completed according to standards and are correctly computed. Experienced hydrographers with demonstrated competence need to have only periodic reviews of the measurements and field notes, unless measurements or observations entail unusual conditions. In the event of unusual conditions, the measurement should be thoroughly reviewed and checked. Reviewers finding deficiencies in the content, accuracy, clarity, or thoroughness of field notes notify the hydrographer of these facts by communicating USGS standards and requirements directly to the hydrographer. Reviewers who find continued deficiencies in the measurement notes of another hydrographer notify the Field Office Chief or Project Chief, who will then reemphasize standards for USGS measurement notes with the hydrographer. 


\section{FIELD-MEASUREMENT NOTES}

- Use Surface Water Measurement and Inspection or paper notes (appendix B) for inspections and measurements

- Station inspection notes include

Date and party

Name of stream and U.S. Geological Survey station number

Outside and inside (stilling well) stage readings

Electronic data logger/data-collection platform stages and times

Readings and times for other sensors

Control and flow conditions

Observed high-water marks (HWMs) and maximum and minimum clip readings

Condition of battery and nitrogen tank, if applicable

Other pertinent information regarding equipment and conditions

- In addition to the above, measurement notes include

Meter type, suspension, and meter number

Stream location for miscellaneous measurement

Stage readings and times before, during, and after measurement

Time measurement started and ended with intermediate times

Bank of stream that measurement was started from

- Miscellaneous field notes

Used for almost anything

Include party, date, station name and number, and observations

- Crest-stage gage notes

For crest-stage gage inspections and service

Include party, date, time, station name and number, stick readings

Quality of marks, HWMs, and other observations

- Snow survey notes

For snow depth, water content, and density

Include party, date, time, snow-course, readings, weather, snow conditions, and remarks

- Level notes

For running levels at stations

Include station number, party, date, and level observations

- Information on all notes should be written as completely and legibly as possible - ask yourself if someone else could understand the notes completely in 10 years' timethe answer should be yes

Figure 5. Field-measurement notes. 


\section{Acceptable Equipment}

The WAWSC uses equipment for the measurement of surface-water discharge that has been determined to be acceptable by the USGS through use and testing. Usually, this equipment has been rigorously tested and calibrated by the USGS Hydrologic Instrumentation Facility (HIF). An array of acceptable equipment for measuring discharge includes mechanical current meters, ADVs, ADCPs, timers, wading rods, bridge cranes, tag lines, and others (Turnipseed and Sauer, 2010; Rantz and others, 1982, p. 82; Smoot and Novak, 1968). Although an official list of acceptable equipment is not available, Buchanan and Somers (1969), Carter and Davidian (1968), and Edwards and Glysson (1988) discuss the equipment used by the USGS.

\section{Mechanical Current Meters}

WAWSC personnel often use the Price AA current meter and the Price pygmy current meter for measuring surface-water discharge. The HIF, which tests a percentage of all new meters received to assure they meet USGS standards, supplies these current meters to the WAWSC. Hydrographers may use other current meters, provided that those meters have been fully tested, calibrated, and field-checked against the appropriate Price meter. Generally, the use of other meters will require an ongoing qualityassurance program to validate their regular use. Methods followed by WAWSC personnel for inspecting, repairing, and cleaning these meters are described in Smoot and Novak (1968, p. 9), Buchanan and Somers (1969, p. 7), Rantz and others (1982, p. 93), Turnipseed and Sauer (2010, p. 51), and in OSW Technical Memorandum 99.06.

The ultimate responsibility for the good condition and accuracy of a current meter rests with the hydrographer using it. A timed spin test made a few minutes before a measurement does not ensure that the meter will not become damaged or fouled during the measurement. Field personnel must assess apparent changes in velocity or visually inspect the meter periodically during the measurement to ensure that the meter continues to remain in proper operating condition. If there is any question regarding the performance of a meter, an immediate spin test may provide the answer.

\section{Spin Tests}

WAWSC procedure requires spin tests prior to each field trip. Hydrographers document spin-test results in SiteVisit directly or by using SWAMI. SiteVisit contains these spin tests in chronological order by meter number (OSW Technical Memorandums 89.07 and 99.06). Spin tests and visual inspections may identify needed repairs to meters. Field personnel note these repairs in SiteVisit for the particular meter being serviced. The Field Office or Project Chief reviews the logs in SiteVisit semiannually to assure that personnel perform regular spin tests, maintenance, and repairs to current meters. If deficiencies are observed during this review of the log, the Field Office or Project Chief orally communicates the noted problems to the hydrographer, who should immediately take the recommended corrective actions.

In addition to the timed spin tests performed prior to field trips, field personnel inspect the meter before and after each measurement to see that the meter is in good condition, that the cups spin freely, and that the cups do not come to an abrupt stop. Descriptive notations made at the appropriate location on the Comment field in the Spin Test form in SWAMI concerning the meter condition, such as "OK" or "free" or other such comments, denote that an inspection has been completed. To ensure that field personnel carry out their responsibilities in maintaining the equipment they use, the Field Office Chief or Project Chief inspects equipment semiannually. They communicate noted deficiencies directly to the hydrographer responsible for the meter, and the hydrographer takes immediate corrective actions. 
Regular repairs involve replacing various parts that make up the current meter. Each field office keeps an inventory of spare parts for use in maintaining current meters. The combined responsibility of all hydrographers is to maintain this inventory and apprise the Field Office Chief or Project Chief when supplies of various parts are low so that they may be ordered immediately. Hydrographers replace damaged cups with new ones as soon as they become bent - bent cups can change the standard meter calibration. For meters that fail spin tests, hydrographers should change the pivot, pivot bearing, head assembly, or yoke until they obtain an acceptable spin test. Field offices dispose of broken parts, but retain worn or slightly damaged parts for reconditioning by the HIF. Periodically, the Field Office Chief or Project Chief will return the aggregated used parts to the HIF for refurbishment, replacement, or recalibration. Metal parts that cannot be refurbished are recycled.

\section{Acoustic Doppler Velocimeters}

Acoustic Doppler velocimeters (ADVs) designed for use with a standard USGS top-setting wading rod are used to make wading discharge measurements. Turnipseed and Sauer (2010, p. 56)_and OSW Technical Memorandums 2004.04, 2010.02, 2010.06 and 2010.07 provide the guidelines for use of the Sontek FlowTracker ${ }^{\circledR}$ ADV. The ultimate responsibility for the good condition and accuracy of FlowTracker ${ }^{\circledR}$ rests with the hydrographer who uses it. All FlowTrackers ${ }^{\circledR}$ must be registered and tracked in the database maintained by the HIF (OSW Technical Memorandum 2010.02), and they should have the most recent firmware installed. Refer to the OSW hydroacoustic Web pages (http://hydroacoustics.usgs.gov/movingboat/mbd_software.shtml) for the most current firmware.

\section{Field Procedures}

The FlowTracker ${ }^{\circledR}$ is designed for mounting on a standard top-setting wading rod. It is recommended that an offset bracket available from the FlowTracker ${ }^{B}$ manufacturer be used to mount the FlowTracker ${ }^{\circledR}$ probe head to the wading rod. Without the bracket, the FlowTracker ${ }^{\circledR}$ sample volume is located about 4 in. from the wading rod. With the bracket, the sample volume is located about 2 in. from the wading rod, closer to the point of depth measurement. The bracket was designed to move the sample volume as close to the wading rod as possible while remaining outside the flow disturbance caused by the wading rod. The FlowTracker ${ }^{\mathbb{B}}$ probe head should be oriented so that the longitudinal axis passing through the center transmitting transducer is parallel to the tagline, and the receiving arm with the red band should be downstream. The wading rod should be held plumb so that the sample volume does not strike a boundary such as the streambed. Hydrographers should use an alignment/level device that comes with new Flowtrackers ${ }^{\circledR}$ or can be purchased from the HIF on the wading rods to aid in holding the instrument in the correct orientation.

Prior to the measurement, the ADV probe is immersed in the stream and the temperature noted (OSW Technical Memorandum 2010.07). At least once daily, the temperature recorded by the ADV is checked against a temperature reading from an independent source, such as a digital thermometer. It is important for velocity and discharge accuracy for the ADV to record water temperature accurately. A 5degree (Celsius) error in temperature would result in a 2-percent error in velocity and discharge measurement. The user ensures that the temperature has stabilized prior to start of data collection. The temperature is noted on the discharge-measurement notes.

Certain environmental factors can affect the accuracy of the measurement with the FlowTracker ${ }^{\circledR}$. Turnipseed and Sauer (2010, p. 58)_and OSW Technical Memorandum 2004.04 recommend that Signal-to-Noise Ratios (SNRs) be greater than 10. Analysis of field data indicates that SNRs can be as low as 4 and adequate data still can be collected. However, data collected with SNRs less than 10 are scrutinized carefully, using other quality-assurance parameters described in the Measurement Quality-Assurance section of OSW Technical Memorandum 2004.04. If low SNRs appear 
to be causing data-quality problems, a different measurement section might be investigated. Backscatter can change with measurement location. If a section with an acceptable SNR cannot be found, do not use the FlowTracker ${ }^{\circledR}$ to make the discharge measurement. If the FlowTracker ${ }^{\circledR}$ is being used in water other than fresh water, the salinity at the data-collection location is measured with an approved sensor, and the measured salinity is entered in the handheld controller Setup Parameters Menu. A 12 parts-per-thousand error in salinity can result in a 2-percent error in velocity and discharge measurement. Avoid measurement sections with abrupt changes in bed topography, such as large rocks or cobbles. The Flow Tracker ${ }^{\circledR}$ sample volume is about 4 in. from the center transmitter transducer. Avoid placing the sample volume within 2 in. of any solid surface.

All policies and recommendations for making wading discharge measurements with Price-type current meters are followed when using FlowTrackers ${ }^{\circledR}$, with the exception of the minimum recommended velocity thresholds, the application of alternative means of measuring velocities in the vertical (Rantz and others, 1982, p. 132), and meter orientation for angled flow. The minimum recommended velocity threshold for the FlowTracker ${ }^{\circledR}$ is $0.1 \mathrm{ft} / \mathrm{s}$; the instrument velocity error at $0.1 \mathrm{ft} / \mathrm{s}$ is about 4 percent. If measured velocities are less than $0.1 \mathrm{ft} / \mathrm{s}$, the measurement should not be rated better than fair. Pay close attention to flow angles reported by the FlowTracker ${ }^{\circledR}$. The FlowTracker ${ }^{\circledR}$ should always be held perpendicular to the tagline.

\section{Office Procedures}

For each measurement of discharge, a file with a .WAD extension is generated and stored on the handheld controller. The .WAD file is downloaded from the controller, and then the FlowTracker ${ }^{\circledR}$ software is used to extract four files from the WAD file:

- A .CTL file - an ASCII file containing the FlowTracker ${ }^{\circledR}$ configuration,

- A .DAT file - an ASCII file containing 1-second velocity component and SNRs,

- A .SUM file - an ASCII file containing station information and summary statistics from each measurement, and

- A .DIS file - an ASCII file containing a discharge-measurement summary.

These Flow Tracker ${ }^{\circledR}$ files are loaded into SWAMI for import into SiteVisit, and copies are archived in a measurement folder in the Data Directory (appendixes C and E) along with the SWAMI style sheet.

FlowTracker ${ }^{\circledR}$ Quality-Assurance Information

A FlowTracker ${ }^{\circledR}$ Quality-Assurance Binder and electronic folder (in combination) is maintained in each field office and in each field office directory (appendix C) by the hydroacoustic point person in the field office and contains the following:

1. A list of FlowTrackers ${ }^{\circledR}$ and serial numbers.

2. Instrument History Log for each FlowTracker ${ }^{\circledR}$, which includes:

- acquisition date

- firmware/hardware upgrade descriptions and dates

- current software

- factory or HIF repairs

- Quality-Assurance Checks (to be performed by the Hydrologic Instrumentation Facility's Hydraulic Laboratory [HIF-HL] at least once every 3 years for existing FlowTrackers ${ }^{\circledR}$, prior to being placed into service for all new FlowTrackers ${ }^{\circledR}$, and prior to being placed back into service for repaired FlowTrackers ${ }^{\circledR}$ ).

3. BeamChecks.

4. Archival procedures and examples. 
A BeamCheck (see FlowTracker ${ }^{\circledR}$ Operations Manual) should be performed (1) when a new instrument is received, (2) if physical damage (for example, dropping) may have occurred, (3) a firmware upgrade or repair was made, and (4) after any quality control (QC) test fails. The BeamCheck files are logged to a file and archived in the data management directory. The name of the BeamCheck file should be recorded on the field note sheet. A QC test must be performed and stored with each measurement, in accordance with OSW Technical Memorandum 2010.06.

The reviewer of a FlowTracker ${ }^{\circledR}$ measurement may use the following list of recommendations to help assess the quality of a discharge measurement. These parameters are computed by the FlowTracker ${ }^{\circledR}$ software. Guidelines for the parameters are:

- Velocity standard error-If the average standard error for the measurement exceeds 8 percent of the mean measurement velocity, the measurement should be rated no better than "fair." If the standard error exceeds 10 percent of the mean measurement velocity, the measurement should be rated no better than "poor."

- Boundary flag_Four possible boundary flags are assigned to each station: "best," "good," "fair," and "poor." A boundary flag of "best" does not guarantee a lack of boundary interference (see the FlowTracker ${ }^{\mathbb{B}}$ Technical Documentation). If the ADV sample volume was striking a solid boundary, a "best" flag likely would be displayed, but the measured velocity could be biased toward zero.

- Velocity spikes - An excessive number of velocity spikes (more than 10 spikes per measurement) could be cause to downgrade the quality of the measurement.

- Flow angles - A good measurement section typically shows some flow-angle variations, but angles should be less than 20 degrees.

- A USGS computer program, DatView, has been developed to assist users of the FlowTracker ${ }^{\circledR}$ in reviewing discharge measurements. It provides quick visual review and highlights data that have possible quality issues.

\section{Acoustic Doppler Current Profiler}

Acoustic Doppler current profilers are used by the WAWSC to make low- to high-water discharge measurements, depending on need and site characteristics. The WAWSC (as of February 2015) has several models of ADCPs from Teledyne RD Instruments ${ }^{\circledR}$, including the Rio Grande ${ }^{\circledR}$, StreamPro $^{\circledR}$, and RiverRay ${ }^{\circledR}$, as well as one M9 ${ }^{\circledR}$ ADCP from SonTek ${ }^{\circledR}$. All personnel operating ADCPs solo, or leading a less experienced person, "are required to complete the USGS training class, Measurement of Streamflow Using ADCPs" (Oberg and others, 2005). Once trained, all ADCP users should continue to attend OSW classes as needed, watch OSW webinars and podcasts, and become familiar with both the OSW Hydroacoustics Forum and Web site (http://hydroacoustics.usgs.gov/) and information contained in the following policy memorandums and reports:

- OSW Technical Memorandum 2011.08, Exposure Time for ADCP Moving-boat Discharge Measurements Made During Steady Flow Conditions.

- Techniques and Methods Report Book 3 - Section A22 (ver. 2.0, December 2013), Measuring Discharge with Acoustic Doppler Current Profilers from a Moving Boat (Mueller and others, 2013; important policies are summarized in OSW Technical Memorandum 2009.05).

- OSW Technical Memorandum 2005.08, Policy and Guidance for Archiving Electronic Discharge Measurement Data.

- OSW Technical Memorandum SW 14.04, Quality Assurance Checks of Acoustic Doppler Current Profilers.

- OSW Technical Memorandum SW 14.02, Policy on Required Minimum Screening Distance for the RiverSurvey or M9. 
- OSW Technical Memorandum 2013.04, Validation of New ADCPs and Their Use in Water Programs.

- OSW Technical Memorandum 2012.01, Processing ADCP Discharge Measurements On-site and Performing ADCP Check Measurements.

- OSW Technical Memorandum 2010.07, Independent Water Temperature Measurement for Hydroacoustic Measurements.

- OSW Technical Memorandum 2014.04, Quality Assurance Checks of Acoustic Doppler Current Profilers.

- OSW Technical Memorandum 2016.02, Quality Assurance Practices for the Mitigation of Systematic Discharge Measurement Errors.

- OSW Technical Memorandum 2016.03, Realease and use of QRev for processing moving-boat streamflow measurements made with acoustic Dopper current profilers.

ADCP Quality-Assurance Information

An ADCP Quality-Assurance Binder and electronic folder (in combination), maintained in each field office or field office directory (appendix C) by the field office hydroacoustic point person, contain the following:

1. List of ADCPs and serial numbers

2. Instrument History Log for each ADCP, which includes:

- model and frequency

- acquisition date (Binder)

- firmware/hardware upgrade descriptions and dates (Binder)

- factory repairs (Binder)

- current software

- instrument calibration checks (HIF ADCP checks at least once every three years or checks after an instrument is first acquired, after factory repair, or after firmware or hardware upgrades)

3. Logs of laser range finder calibration checks

4. List of trained operators in the WAWSC

5. Archival procedures and examples

6. Guide for processing and reviewing ADCP measurements

\section{Field Procedures}

1. Prior to going to the field, the operators ensure that the ADCP is in working order with the latest approved firmware, their laptop contains the latest approved manufacturer software and USGS software (that is, QRev), they have sufficient space on the flash memory card or USB drive for temporary backups, and they have a method and tools (such as a laser range finder, tape measure, or level rod) for measuring edge distances.

2. Prior to every discharge measurement, the ADCP time is set, diagnostic tests are performed, and the results are stored on the field computer. Diagnostic tests should be documented on the ADCP discharge-measurement field form.

3. Calibration of the compass is encouraged prior to measurements, but compass calibration prior to the measurement is mandatory when using GPS for navigation, using the loop method for moving bed corrections, or when velocity direction is important. The OSW Hydroacoustics Web page (http://hydroacoustics.usgs.gov/movingboat/mbd_guidance.shtml) documents important best practices for compass calibrations. 
4. The depth to the transducer below water surface is measured before each measurement.

5. Prior to each measurement, the temperature measured by the ADCP must be compared with an independent water temperature measurement made adjacent to the ADCP and recorded on the field measurement form.

6. Prior to each measurement, a moving-bed test is performed using one of the following acceptable methods, in order of preference: (1) The loop method (not recommended when using a TRDI RiverRay with the older Honeywell compass, or a SonTek M9), (2) a stationary test with GPS, or (3) a stationary test with no GPS. Detailed descriptions of these methods are provided in appendix B of Mueller and others (2013, p. 52-63). Stationary tests should be recorded for no less than 10 minutes. If the stationary position is maintained by a tether or anchor so that upstream or downstream movement of the ADCP is not possible, the moving-bed test may be recorded for no less than 5 minutes. If a site routinely has a moving bed and GPS is always used with the ADCP, a moving-bed test still is required, but it needs to be only 5 minutes. If using the loop method, the duration of the loop should be 3 minutes or greater, the boat speed should be consistent, and the boat speed should not exceed 1.5 times the mean downstream water velocity.

7. The estimates used for edge distances shall always be measured. Distance may be measured using a laser range finder, level rod, tag line, or rule.

8. When using an RD Instruments ADCP with WinRiverII software, operators use the Configuration Wizard to set up the measurement. If any settings other than the Configuration Wizard settings are used, the reasons for the user settings are explained on the measurement note sheet.

9. In accordance with OSW requirements, an even number of (reciprocal) transects with a minimum of 720 seconds total exposure time will be made under steady-flow conditions. The measured discharge will be the average of the discharges from all valid reciprocal transects. Reciprocal transects should always be made to reduce potential directional biases. For policy detail, see OSW Technical Memorandum 2011.08. Note: There are exceptions for unsteady flow.

10. Wading ADCP measurements generally are discouraged; however, if the field hydrographer judges that a wading ADCP measurement is the most appropriate option at a specific site and time, the hydrographer must have demonstrable knowledge of the limitations and precautions to be taken for wading ADCP measurements, follow WAWSC protocol when making the wading ADCP measurement (appendix D), and document the reason for making the wading ADCP measurement.

11. Immediately after completion of a measurement, the measurement should be processed before leaving the site. If the measurement does not plot within an acceptable percentage of the current rating curve or the previous trend of measurements and a satisfactory explanation cannot be found, then a check measurement with a different hydroacoustic instrument should be made. If another acoustic instrument is not available at the time, completely shut down the ADCP, reconnect, and make another measurement with the same instrument. All measurement data and diagnostic tests should be backed up on removable media, such as flash-memory cards or USB drives, and stored separately from the field computer before leaving the site.

\section{Office Procedures}

ADCP data are transferred to permanent storage on the WAWSC server within 2 working days of returning to the office, and archived and reviewed within 5 working days after returning from the field. After reviewing the measurement, and if you are not using SWAMI to record the measurement and you are creating a hard copy of the measurement notes, print the "Q Measurement Summary" 
(WinRiverII $^{\circledR}$ ) or "Discharge Measurement Summary" (RiverSurveyor Live ${ }^{\circledR}$ ), cut it no larger than 8 in. wide by 10 in. long, and attach it to the field note sheet for review and storage. Electronic measurement files, including diagnostic files, are retained and archived in accordance with the file-naming conventions and directory structure shown in Appendix E. An example of data archival for ADCP measurements is available in the ADCP Quality-Assurance Binder.

The ADCP operator is responsible for archiving all ADCP measurement and diagnostic files, processing all measurements, entering the measurement data into the database, and finding a trained ADCP operator to review each measurement.

The reviewer of an ADCP measurement is responsible for ensuring that correct methods were used to collect and process the measurements, measurement notes are accurate and complete, and electronic measurement data have been archived correctly. If any changes are made during the review process, the changes should be discussed with the original ADCP operator and the database should be updated.

\section{Other Direct Methods of Measuring Discharge}

Other direct methods of measuring discharge include the tracer-dilution method, volumetric methods, and portable weirs and flumes (Buchanan and Somers, 1969; Rantz and others, 1982; Kilpatrick and Schneider, 1983;Turnipseed and Sauer, 2010). WAWSC procedure dictates that USGS and OSW techniques and guidelines are followed when discharge measurements are made with these or any other selected method of measurement.

\section{Indirect Methods of Measuring Discharge}

In many situations, especially during floods, it is impossible or impractical to measure peak discharges by means of a direct method. There may not be sufficient warning for personnel to reach the site to make a direct measurement, or physical access to the site during the event may not be feasible. A peak discharge determined by indirect methods becomes, in many situations, the best available means of defining the upper portions of the stage-discharge relation at a site (Rantz and others, 1982, p. 334). This is important because the results from extrapolation of the stage-discharge relation (rating) may be unreliable; USGS generally does not accept extrapolation of the rating beyond twice the measured discharge at a gaging station. Thus, indirect measurements are important when high flows are much higher than any measurements made by direct methods (Turnipseed and Sauer, 2010, p. 86; Rantz and others, 1982, p. 334).

The WAWSC follows data-collection and computation procedures for indirect measurements presented in Benson and Dalrymple (1967). That report includes policies and procedures related to site selection, field survey, identification of high-water marks, the selection of roughness coefficients, computations, and the written summary. The WAWSC also follows procedures for measurement of peak discharge by indirect methods presented in Rantz and others (1982, p. 273).

In addition to the general procedures presented in Benson and Dalrymple (1967), the WAWSC follows guidelines presented in other reports that describe specific types of indirect measurements suited to specific types of flow conditions. Barnes (1967) and Benson and Dalrymple (1967) describe the slope-area method used by the USGS, which is based on the Manning equation. Arcement and Schneider (1989) describe procedures for selecting the roughness coefficient. Fulford (1994) discusses the computer programs SAC, used for computing peak discharge with the slope-area method, and CAP (Fulford, 1995), used to compute peak discharge at culverts. A set of graphical user interfaces (GUIs) have been developed for SAC and CAP, referred to as SACGUI and CAPGUI, to facilitate the use of the two programs (U.S. Geological Survey, 2013https://xcollaboration.usgs.gov/wg/osw/OSWNotes/FY13 Note 
Archive/Forms/DispForm.aspx?ID=33). Jarrett and Petsch (1985) discuss NCALC, used to compute Manning's n value from a known discharge, water-surface profile, and cross-section properties. Bodhaine (1982) describes procedures for the determination of peak discharge through culverts, based on a classification system that delineates six types of flow. Models described by Matthai (1967), along with the Water-Surface Profile Computation model (WSPRO) described by Shearman (1990), show how peak discharge can be estimated at sites where open-channel width contractions occur, such as flow through a bridge structure. OSW Technical Memorandum 92.11 discusses debris-flow conditions, which are most common in small mountainous basins. Water-surface profile studies involve delineations of flood plains or extensions to stage-discharge relations at streamflow sites. In such efforts, WAWSC personnel follow the procedures associated with step-backwater methods described in Davidian (1984). OSW Technical Memorandum 87.05 describes how to use WSPRO to compute watersurface profiles with step-backwater methods, and a similar computer program, HEC-RAS, is described by the U.S. Army Corps of Engineers (2008) .

General guidelines that are followed by the WAWSC when making indirect measurements include those discussed in OSW Technical Memorandum 92.10 and in Shearman (1990). Violation of any one of the general guidelines does not necessarily invalidate an indirect measurement (OSW Technical Memorandum 92.10), but should be cause for careful scrutiny and analysis. Criteria that might invalidate an indirect measurement include possible presence of a hydraulic jump, a discontinuous water-surface slope, inadequate fall between cross sections, or evidence of bed changes between the time of the flood and the indirect measurement.

The Surface-Water Specialist, Data Chief, and Field Office Chief or Project Chief ensure that indirect measurements are performed and documented correctly. These personnel should review proper procedures and documentation with the data-collection staff at the beginning of the flood season each year. If deficiencies are found during the review, actions taken to remedy the situations include discussing the deficiencies with the person or persons completing the indirect measurement or providing proper training. The Surface-Water Specialist refers questionable and difficult indirect measurements to Surface-Water Specialists in other Water Science Centers, or to the Water Science Field Team-West Surface-Water Specialist.

The Field Office Chief determines when and where indirect measurements are made, with guidance from the Surface-Water Specialist. Generally, an indirect measurement should be performed when the estimated discharge is more than twice the highest direct measurement made at the site. For the purposes of quality assurance, validation, and maintenance of training and skills, a few indirect measurements should be made annually. Comparing a direct measurement and indirect measurement at similar stages is one of the best ways to verify or estimate the surface roughness coefficient (n value) for future indirect measurements.

The hydrographer should identify and flag high-water marks as soon as possible after the flood, and after obtaining permission from property owners. Because the quality and clarity of high-water marks are best just after a flood, personnel traveling in the field need flagging equipment such as nails and plastic markers, spray paint, paint sticks, and brightly-colored flagging tape in their field vehicles. Because selection of a suitable reach of channel is an extremely important element in making an indirect measurement, at some streamflow-gaging-station sites, the stream reach for indirect measurements at specified ranges of stage has been preselected, and that information has been included in the station description.

After the computation of each indirect measurement, the Field Office Chief or Project Chief, Data Chief, or Surface-Water Specialist checks graphs, field notes and data, plotted profiles, maps, calculations or computer output, and written analyses associated with the measurement. A single labeled folder organizes the information, which is then included with the primary folder for use in computing or 
reviewing the record. Historical indirect measurements become part of the archived indirect measurement files.

The WAWSC maintains and updates the peak-flow data files, including computer database files (OSW Technical Memorandum 92.10). The Field Office Chief or Project Chief ensures that appropriate indirect-measurement results are entered correctly into the peak-flow files. 


\section{Crest-Stage Gages}

Crest-stage gages, or CSGs, are used as tools throughout the USGS for determining peak stages at otherwise ungaged sites, confirming peak stages at selected sites where recording gages are located, confirming peak stages where pressure transducers are used, and determining peak stages along selected stream reaches or other locations, such as upstream and downstream from bridges and culverts. When CSGs are used to confirm peak stages at recording gage sites, they need to be installed as close as possible to the transducer or orifice for the gage. CSG peak stages are invaluable for performing indirect measurements. At sites without CSGs, hydrographers must depend on obtaining numerous high-water marks to obtain flood profiles. The OSW requires quality-assurance procedures comparable to those used at continuous-record stations for the operation of CSGs and for the computation of annual peaks at CSGs (OSW Technical Memorandum 88.07 and OSW Technical Memorandum 2014.06).

Part of the WAWSC surface-water program includes operation of CSGs. Generally, CSGs supplement other gage instruments and are used to confirm or determine peak stages. The procedures followed by the WAWSC in the operation of CSGs are presented in Rantz and others (1982, p. 9, 77, 78). One or more gages at each selected site mark peak water-surface elevations. Culvert stations, or other sites where water-surface elevations are required to compute the amount and type of flow through the structure, may require upstream and downstream CSGs.

When CSG data are used to determine peak flows, field personnel develop stage-discharge relations from direct or indirect high-water measurements. Then, direct or indirect measurements obtained every year verify the rating or become the basis to adjust it. Hydrographers run levels to the gage every 3 years or as soon as possible after significant changes in the gage because of damage to the gage, reconstruction, or other such situations. An outside high-water mark confirms recorded peak stages whenever possible. The hydrographer flags this mark as soon as possible after the event so that personnel can determine the elevation of the high-water mark the next time levels are run.

Field personnel enter CSG observations on a CSG Inspection Form in SWAMI, or as a backup to SWAMI, personnel may use a note sheet (appendix B6), measurement note sheet, or any other note sheet (appendix B), as long as they include all the necessary information. Properly completed CSG field notes contain, at a minimum, initials and last name of field personnel, date, time of observation, the reading above the base bolt, mathematics used to calculate elevation, and any pertinent notes regarding the conditions under which the data were collected. The CSG readings are entered into NWIS using the SiteVisit program.

The Field Office Chief ensures that correct data-collection procedures are used by personnel in installing, maintaining, and reading CSGs. The Chief periodically reviews CSG note sheets and communicates any observed deficiencies to the appropriate hydrographer, along with recommendations to correct them. The Field Office Chief assures that hydrographers are properly trained in operating CSGs.

\section{Artificial Controls}

Artificial controls, including broad-crested weirs, thin-plate weirs, and flumes, are built in stream channels for simplifying the procedure of obtaining accurate records of discharge (Rantz and others, 1982, p. 12). Such structures serve to stabilize and constrict the channel at a section, reducing the variability of the stage-discharge relation. In the WAWSC, these structures are most often used in lowflow projects rather than for long-term gaging stations. 
In situations where artificial controls are installed as permanent structures, determination of stage-discharge relations depends on the design rating when direct measurements cannot be made. In most cases, however, hydrographers regularly make volumetric or current-meter measurements to validate the artificial control estimates. WAWSC personnel use portable weir plates and flumes in situations that include very low flow or unidentifiable controls. Buchanan and Somers (1969, p. 57) and Rantz and others (1982, p. 263) describe the methods used in applying these portable devices.

The Field Office Chief or Project Chief ensures that field personnel use artificial control designs appropriate for the gaging site and that they use correct methods to install and operate the control. When installing an artificial control, the WAWSC personnel take into account the criteria for selecting the various types of controls, principles governing their design, and the attributes considered to be desirable in such structures (Carter and Davidian, 1968, p. 3; Rantz and others, 1982, p. 15, 348; Kilpatrick and Schneider, 1983, p. 2, 44).

During field inspections of artificial controls, hydrographers write specific information pertaining to control conditions on field note sheets for the purpose of assisting in analysis of the surface-water data. These notes include height of water above the control, the amount of free fall and submergence at weirs, time and date of observation, station number and name, name or initials of the field person, and comments on channel conditions upstream and downstream of the artificial control. Regular maintenance at artificial controls includes cleaning the control, cleaning the staff plate, and checking for and repairing any observed leaks. Field personnel should consult the Field Office Chief or Project Chief for help in solving issues associated with artificial controls.

\section{Flood Conditions}

Flood conditions present issues that otherwise do not occur on a regular basis. These issues can include difficulties in gaining access to a streamflow gage or measuring site because roads and bridges are flooded, closed, or destroyed. Debris in the streamflow can damage equipment and present dangers to personnel collecting the data. Rapidly changing stage or conditions requiring measurements to be made at locations some distance away from the gage can create difficulties in associating a gage height to a measured discharge. Because of the difficult and changing conditions, field personnel follow a series of specific guidelines during floods. These guidelines consist of a WAWSC Flood Plan and Station Lists of Flood Priority.

The WAWSC Flood Plan provides WAWSC personnel with basic guidelines for collecting, analyzing, and reporting flood-related data, and is intended to ensure efficient and complete coverage of all floods. The flood plan describes responsibilities before, during, and after a flood, informationalreporting procedures, and field-activity priorities. The flood plan serves as a central reference for emergency communications, telephone numbers for key WAWSC personnel, Local Receiving Ground Station codes for accessing streamflow gages equipped with telemetry, and methods of obtaining the most current data.

The Data Chief and Surface-Water Specialist ensure that the flood plan includes all appropriate information, review the flood plan annually, and make updates to the plan as required. The Data Chief provides copies of the flood plan to all field office personnel and key project personnel who may assist in flood measurements and monitoring. Individuals who receive a copy of the plan keep the document near their desk or with their field folders, and maintain copies of key information, such as telephone numbers, in their field vehicles. The Field Office Chief or Project Chief ensures that individuals who receive a copy of the plan are fully versed in the contents of the plan. 
The Station Lists of Flood Priority contain several different categories of flood-related information that enable the WAWSC flood coordinator to quickly formulate a plan for responding to a flood and aid each field person in rapidly making decisions about which stations and in what order they should collect flood data. This spreadsheet contains station flood priorities, current flow and stage data and graphs, flood-frequency discharges, station flow and flood data, listings of which stations are maintained by which hydrographers, and much more.

During a flood, the Field Office Chief, in conjunction with the Data Chief, coordinates flood activities. Personnel who are not already in the field during flood conditions should first contact the Field Office Chief for their assignments. If the Field Office Chief is not available, field personnel should come directly to the office with an overnight bag in case of extended work hours. For personnel who are already in the field, their first responsibility during flood conditions is to contact the Field Office Chief for their assignment. If the Field Office Chief or the Data Chief can be reached, field personnel should call and consult with other technical persons or co-workers in the office and, using the WAWSC Flood Plan and the WAWSC Station Lists of Flood Priority as guides, they should decide which stations they should proceed to first. Personnel who arrive at a gaging station to find that a flood has occurred should make a discharge measurement, note and flag high-water marks as appropriate, and record any pertinent observations about the flood or weather conditions before proceeding to their next site. WAWSC personnel apply methods such as observing high-water marks inside and outside wells, determining maximum clip readings, and taking CSG readings to determine peak stage at gaging stations (Rantz and others, 1982, p. 60).

WAWSC personnel follow policies and procedures stated in numerous publications and memorandums when collecting surface-water data during floods. Turnipseed and Sauer (2010, p. 35, 41) and Rantz and others (1982, p. 159-170) presented techniques for current-meter measurements of flood flow. Benson and Dalrymple (1967, p. 11) discuss procedures for identifying high-water marks for indirect discharge measurements. OSW Technical Memorandum 92.09 and Buchanan and Somers (1969, p. 54) present information on adjustments applied to make measured flow hydraulically comparable with recorded gage height when discharge measurements are made a distance from the gaging station. It is the responsibility of all personnel with questions about particular policies or procedures related to flood activities, or who recognize their need for further training in any aspect of flood-data collection, to address their questions to the Field Office Chief or Data Chief.

The Data Chief reviews all activities related to floods. This review includes seeing that guidelines and priorities stated in the flood plan are followed and that the guidelines appropriately address WAWSC requirements for obtaining flood data in a safe and thorough manner. The Data Chief communicates any deficiencies in following the flood plan orally or in writing to the Field Office Chiefs, who in turn provide corrective measures and (or) training for field personnel, as appropriate.

\section{Low-Flow Conditions}

Because of the typically sparse precipitation during the summer in Washington, low flows occur at many streams in late summer and early autumn. Low flows also may occur during periods of severe cold in winter when water is frozen in the snowpack and glaciers, or water may be frozen in the stream itself. WAWSC procedure requires that field personnel make gage height-of-zero-flow determinations at least annually during low flow at wadable stations with section control and record the information on the Discharge Measurement Notes and in SiteVisit in NWIS. These data help hydrographers extend rating curves down and help to determine an appropriate stage-discharge rating offset for the section control part of the rating. WAWSC personnel monitor near-real-time data to decide when it is best to visit a site to obtain low-flow discharge measurements near the lowest flows of the year. 
Low-flow conditions differ from those observed during periods of medium and high flow. Lowflow discharge measurements define or confirm the lower portions of stage-discharge relations for gaging stations and, as part of seepage runs, they help identify channel gains or losses. Gains and losses can result either from the hydraulic connection between the stream channel and adjacent aquifers or from underflow in gravel streambeds. Underflow is the portion of streamflow that flows through gravel streambeds. Streamflow during low-flow periods in late summer and early autumn can change substantially within short distances as a result of variable amounts of underflow along a stream reach. Therefore, low-flow measurements made to define the low-flow portion of stage-discharge ratings for gages on streams with gravel streambeds should be made as close as possible to the low-flow controls for those gages. Additionally, low-flow data help in the interpretation of other associated data, such as water levels in groundwater wells. Low-flow measurements also help define the relation between lowflow characteristics in one basin and those of a nearby basin for which more data are available (OSW Technical Memorandum 85.17). The designated wading-measurement location must be documented in the station description.

In many situations, factors during low flows reduce the accuracy of discharge measurements. These factors include algae growth that impedes the free movement of current-meter buckets and large percentages of the flow moving in the narrow spaces between cobbles. When measuring conditions are considered to be unsuitable, the hydrographer physically improves the cross section for measurement by removing debris or large cobbles, constructing dikes to reduce the amount of non-flowing water, or other measures (Buchanan and Somers, 1969, p. 39). In some cases, field personnel must clean the control, but only after reading and recording the gage height before cleaning. After modifying the cross section or control, personnel allow the flow to stabilize before initiating a discharge measurement. Because the modification will almost certainly affect the stage, personnel record gage-height readings on the field notes before and after they modify the channel so that appropriate adjustments to the gageheight record can be made. They also should note these readings on gage-shelter documents.

The Field Office Chief or Project Chief ensures that WAWSC personnel use appropriate equipment and procedures during periods of low flow. Reviewing field measurement notes during the records review, or more often in the case of drought conditions, accomplishes this task. During periods of low flow, the Data Chief, Field Office Chief, or Project Chief provides answers to questions from WAWSC personnel pertaining to data collection during periods of low flow.

\section{Cold-Weather Conditions}

Surface-water activities in the WAWSC, particularly in field offices in eastern Washington, include making streamflow-discharge measurements during freezing weather conditions. Sub-freezing air temperatures, near-freezing water temperatures, wind, snow, and ice can create difficulties in collecting data as well as dangers to field personnel. Employee safety remains the highest priority in collecting streamflow data during winter periods, or any other period.

Only during unusually severe cold periods do streams in Washington completely freeze over, but when they do, WAWSC personnel follow procedures for discharge measurements under ice cover presented in Buchanan and Somers (1969, p. 42), Rantz and others (1982, p. 124-128), Turnipseed and Sauer (2010, p. 29) and OSW Technical Memorandum 84.05. These publications and guidelines address issues such as drilling holes in ice with drills, chisels, and augers; supporting reels and current meter assemblages on ice; information on computing depth of water under ice; and which types of equipment to use to measure flow under ice.

The OSW recommends the use of a type AA current meter built with a Water Survey of Canada (WSC) winter-style yoke with a conventional metal-cup rotor for discharge measurements under ice cover with slush-free conditions. For conditions where slush ice is present, ADCPs can be used. The 
Water Survey of Canada (Campbell, 2014) has a useful draft report on the use of ADCPs under the ice. For mechanical meters, the OSW recommends the use of the WSC winter-style yoke with a polymer rotor for slush conditions (OSW Technical Memorandum 88.18). Although polymer rotors are not allowed during any other conditions (OSW Technical Memorandum 90.01), the OSW considers the superior ability of the polymer rotor to shed slush ice and retard freezing in ice-covered streams to be more important than the turbulent-flow-related inaccuracies associated with the rotor (OSW Technical Memorandum 92.04). The OSW also regards the regular AA meters with conventional metal-bucket rotors to be acceptable for use in slush-free conditions if cutting the required larger holes through the ice is feasible (OSW Technical Memorandum 92.04). The Field Office Chief or Project Chief ensures that personnel use the correct instruments for the conditions present and follow proper procedures for datacollection activities during freezing winter conditions. Annual reviews of the available instruments and their uses fulfills this responsibility.

Winter conditions demand that safety be of the utmost importance. Field personnel will contact their Field Office Chief or another designated person by an agreed-upon time each day to verify that they are safe and to provide updates on their plans and whereabouts for future data collection. Field personnel will maintain extra winter-type gear in their vehicles, such as insulated boots, down jackets, wool socks and caps, wool blankets, matches in a water-resistant case, and a pocketknife. Personnel should drive vehicles fully equipped for winter conditions. At a minimum, this would include chains, a shovel, a hatchet, a chain saw, a regular saw, and an emergency first aid-kit.

\section{Index-Velocity Meter}

The WAWSC occasionally uses an acoustic Doppler velocity meter (ADVM) installed at a gaging station to record an index-channel velocity for the computation of continuous discharge records. Because this method of data collection and discharge computation is not frequently used in the WAWSC, it is recommended that personnel who use ADVM instruments, for the collection of indexvelocity data and later computation of discharge records, complete the USGS training class, Streamflow Record Computation using ADVMs and Index-Velocity Methods, as well as become familiar with information contained in USGS Techniques and Methods, book 3, chap. A23, Computing Discharge Using the Index Velocity Method (Levesque and Oberg, 2012; important policies are summarized in OSW Technical Memorandum 2012.04). The OSW Hydroacoustics Web page for Index Velocity (http://hydroacoustics.usgs.gov/indexvelocity/index.shtml) is a useful resource including a list of USGS publications on the topic, Best Practices, and Technical Quick Sheets, as is the Index-Velocity section of the USGS-maintained Hydroacoustics Community forum

(https://hydroacoustics.usgs.gov/list_info.shtml).

\section{Installation}

1. A thorough site reconnaissance is required prior to installation of an index-velocity meter at an existing gaging station or establishment of a new index-velocity-meter station. The site reconnaissance should include a series of discharge measurements made at the potential ADVM location over a range of flows, gage heights, and velocities, as well as a characterization of the channel bed for stability. Reconnaissance also may include channel surveys and the collection of temperature profiles. Other necessary considerations include protection of the instrument, limitations of cable length for power/communications, and adequate power supply.

2. The data collected from the reconnaissance are used to ascertain the likely success of using an index-velocity meter at that location. It is necessary to be able to derive a stable relation between index and mean channel velocity. Being able to sample in or near a stable region of maximum or higher velocity increases the chance of successfully indexing the velocity. Aspect ratios 
(range/depth <20) and bridge-pier wake-turbulence zone can be computed to determine if the ADVM sample volume will reach a zone of stable velocities. Index-velocity gage-site selection and ADVM installation considerations are further documented by Levesque and Oberg (2012).

3. Once reconnaissance data are evaluated and a location is selected, an ADVM is installed to collect preliminary continuous velocity data over one large range-averaged cell and smaller multi-cells. A USGS “ADVM Installation and Setup Form" (August 2011) should be used to document installation hardscape and ADVM programming specifics. Additionally, if the ADVM software allows, it is recommended to record a log file that documents the ADVM system, configuration, setup, and deployment. Hardscape and final programming information also should be included in the Station Description.

4. After preliminary data are collected across a range of flows, gage heights, and velocities, the data are evaluated and the cell ranges are adjusted as needed. It is possible that preliminary data evaluation will indicate a need to find a better ADVM location.

5. When cell ranges are finalized, the permanent programming information is again documented in a USGS "ADVM Installation and Setup Form" and added to the Station Description.

\section{Field Procedures}

The following procedures are followed during visits to stations equipped with index-velocity meters. Appendix 2 of Levesque and Oberg (2012) provides a quick reference guide that ensures that all steps will be taken:

1. If available, a log file is recorded while servicing the ADVM. All ADVM data, including log files, beam checks and recorder data, are stored in an ADVM directory under the station number.

2. A temperature reading from an independent source, such as a digital thermometer, is taken near the instrument. The temperature is recorded in the field notes along with the time of the reading.

3. A beam-amplitude diagnostic test (beam check) is run and logged in a file. Check the beamamplitude test to ensure that the ADVM sampling zone is free of obstructions and is sized so that beam amplitudes at the end of the sampling zone are a minimum of 5 counts above the instrument noise level. Beam check results are noted in the field form.

4. Any sampling-zone changes most likely will result in the need for a new index-velocity rating. However, if sampling-zone charges are made, they must be noted in field notes and on station log. Refer to USGS Techniques and Methods, book 3, chap. A23 (Levesque and Oberg, 2012), for further guidance.

5. The data logger is downloaded and formatted during each site visit. If a measurement is made and 1-minute data are collected, the data are downloaded after the measurement is made and are entered into NWIS at the office.

6. Annually for the first 3 years, the standard-area cross section is surveyed to ensure that the channel geometry has not changed significantly. For channels with known scour or fill potential, or for channels with the potential for dredging, the standard cross section may need to be checked more frequently. If after 3 years of annual surveys, the standard-area cross section proves stable, then it should be resurveyed every 3 years or whenever significant channel or rating changes are suspected. 
7. The frequency of discharge measurements is dictated by stability of the stage-area and indexvelocity ratings, and by the range of measurements used to define the ratings. Changes in indexvelocity instrumentation or changes to existing instrument program parameters (for example, ADVM sampling-zone size changes) likely necessitate the need for a new index-velocity rating and, hence, more-frequent measurements to establish the new rating. It may be possible to reduce measurement frequency once a stable rating has been established for a wide range of flows. All sites, however, must be measured at least six times a year.

8. When making discharge measurements, it is recommended that the index velocity and measurement interval and averaging period be set to 1 minute. Averaging the 1 -minute data over the duration of the discharge measurement(s) will reduce the overall standard deviation and improve the synchronization of the index velocity and the discharge data. If stage is not changing in a steady, predictable way, the stage measurement interval also should be set to 1 minute during discharge measurements. This continuous measurement of index velocity and stage allows more precise synchronization to the discharge measurement start and end times, and provides a representative measure of the index velocity and stage changes for the duration of the discharge measurement

\section{Data Quality Assurance}

All data-quality parameters available are used to assess the quality of the velocity (and stage) data used to generate discharge records. For ADVMs, these parameters can include cell end, velocity standard deviation, velocity y-component, water temperature, and signal strength (average backscatter amplitude). Unit-value plots are valuable for examining these quality-assurance parameters.

\section{Discharge Computation:}

The same general USGS policies and recommendations that apply to stage-discharge methods used to produce discharge records apply to index-velocity methods. Thus, guidelines for the production of streamflow records presented in the section, "Processing and Analysis of Surface-Water Data," apply to index-velocity methods. Policies and recommendations regarding stage data, such as the editing or deleting of unit values, apply to velocity unit values as well. Likewise, guidelines for records documentation, including the station analysis, daily-values tables, and other supporting materials, are applicable to index-velocity records. For further guidance on discharge computation using the indexvelocity method, see Levesque and Oberg (2012).

\section{Processing and Analysis of Surface-Water Data}

The computation of streamflow records involves the analysis of field observations and field measurements (including the stage record), the determination of stage-discharge relations, adjustment and application of those relations, and systematic documentation of the methods and decisions that were applied. After the 2013 water year records, the Annual Data Report was discontinued and the Continuous Record Processing procedures were begun to review and approve records on a less-thanannual timeframe. The WAWSC computes streamflow records and publishes those data using NWISWeb. The procedures followed by the WAWSC pertaining to the processing, analysis, and computation of streamflow records are based on those described by Sauer (2002), Rantz and others (1982), and Kennedy (1983). 


\section{Measurements and Field Notes}

The gage-height information, discharge information, control conditions, and other field observations entered into SWAMI - or as a back-up method, this information written by personnel onto the measurement note sheets and other field note sheets-form the basis for records computation for each gaging station. The USGS stores indefinitely measurements and field notes that contain original data (Hubbard, 1992). The WAWSC stores SWAMI information in SiteVisit. Handwritten measurements and other field notes for the current water year are stored in the primary station folder. The field offices store the previous water year's measurements and notes for each station in a separate filing cabinet.

Most streamflow discharge measurements in the Washington Water Science Center (WAWSC) are being collected electronically. AquaCalc ${ }^{\circledR}$ data loggers, FlowTracker ${ }^{\circledR}$ ADVs (acoustic Doppler velocimeters), and ADCPs (Acoustic Doppler Current Profilers) are some of the instruments used to electronically collect stream-discharge information. A WAWSC plan for storing these data was originally developed in 2006 to facilitate the retrieval of the information and to ensure that the data are permanently archived as required by U.S. Geological Survey policy. Currently (2014), these data are stored on the WAWSC server according to instructions outlined in appendix E. WAWSC procedure regarding checking discharge measurements is to check all measurements. Procedures involved in checking a measurement include reviewing the mathematics (unnecessary for most electronically recorded measurements), velocities, width calculations (generally unnecessary for electronically recorded measurements), gage heights, and corrections; comparing the measurement gage heights with those from the recording instruments in the computer files; and other items (Kennedy, 1983, p. 7).

The hydrographer enters measurements into the NWIS database using SiteVisit, a component of the Automated Data Processing System (ADAPS), and keeps the original measurement notes, or optionally, a print of the SWAMI output made legible with a stylesheet for measurements made during the current water year in the primary station folder. The hydrographer enters the measurement into the computer system and makes needed shifts/corrections within 1 week of the field trip during which the measurement was made, unless there are extenuating circumstances or other arrangements have been made by the Field Office Chief.

Changes to the information in SiteVisit after it has been entered into SiteVisit must be tracked using comments. Edits to SiteVisit can be made in one of two ways - either (1) by editing the information in SiteVisit and including a comment that documents the change, or (2) by editing the SWAMI file and re-entering it into SiteVisit. The preferred method for the WAWSC is to make changes by editing the SWAMI file and then re-importing the file into SiteVisit. To do this, the original SWAMI XML file should be copied and the word "original" should be added to the file name (ex.

S_12028060_20140502_161100.xml is copied and a second file is named S_12028060 20140502 161100_original.xml). The file without "original" in the file name is reloaded into SWAMI, the edits are made, and then comments are made in the "Comment:" field in SWAMI that document the initials of the person making the edit, the date of the edit, the nature of the edit, and why it was made. The SWAMI file is then reloaded into SiteVisit using the "Import and Overwrite" option. More information is available on the USGS HydroTube-SWAMI Series Web page (http://www.usgs.gov/humancapital/ecd/hydrotube/swami-29.html). 


\section{Continuous Record}

The WAWSC collects surface-water gage-height information as continuous-record data (hourly, 30-minute, 15-minute, or 5-minute values, for example) in the form of electronic readings in a data logger, telephone modem, and electronic transmissions by satellite. Personnel apply stage-discharge ratings to convert gage-height record to discharge record. Therefore, the accuracy of gage-height record largely indicates the accuracy of computed discharges.

Since October 1, 1999, WAWSC policy is to use real-time data as the primary record whenever possible. Exceptions are for stations with Synergetics DCPs, Bureau of Reclamation sites, sites with many regularly missing transmissions, and other extenuating circumstances. All real-time data ratings and shifts are updated every 15 minutes. ADAPS will automatically calculate a mean daily value unless more than 240 minutes of data are missing from the DCP transmissions. In case of missing data, backup record is inserted from data-logger data using ADAPS.

Hydrographers assemble the gage-height record for the period of analysis in as complete a manner as possible. They identify periods of inaccurate gage-height data, then correct those data using data corrections and shifts, or flagged as deleted (the raw data are still in the database), as appropriate. WAWSC policy is to delete data that appear erroneous and cannot be verified. Authors discussing the assembly of gage-height record and procedures for processing those data include Sauer (2002), Kennedy (1983, p. 6) and Rantz and others (1982, p. 560, 587).

The WAWSC uses various methods for entering stage data into the computer files. For stations with DCPs, the computer uses specific software (ADAPS) to automatically store stage data transmitted from the satellite. In ADAPS, the primary instrument (data descriptor) for current records is denoted with an asterisk. Personnel transfer data from Electronic Data Loggers (EDLs) to portable laptop field computers, and then transfer the data into USGS computer files using appropriate software for that purpose.

Gage-height record is never estimated. In the USGS computer files, flags after the original data denote the source: "e" from EDLs; "s" from DCPs; and " " for ADAPS interpolated data (in edited unit values). These and other flags are defined in the ADAPS documentation, which can be accessed from ADAPS. Hydrographers flag estimated mean daily flow data in the computer with an " $\mathrm{e}$ " before the value. In all cases, the hydrographer checks the data for missing and erroneous values using computer software for that purpose.

Personnel may fill periods of bad or missing data with data from backup recorders. They enter these data into the computer files using computer software if possible, or by hand, and check for consistency in the number and timing of data values with other electronic data immediately before and after the periods with bad or missing data. For DCP stations, data for missing transmissions will be entered from backup sources. When personnel use data from backup recorders and enter those data in the computer, they document the periods and source of the data in the station analysis in the primary station folder. Likewise, hydrographers document periods and sources of estimated data in the station analysis in the primary folder. Typically, the hydrographer who operates and maintains the gage is the one who enters, maintains, and documents the stage data in the computer files.

\section{Procedures for Computing, Reviewing, and Publishing Records}

Hydrographers process the records for the stations to which they are assigned. The hydrographer assigned to the station usually works the first computation for the records associated with it. After the first computation, a different hydrographer checks the work of the first. Finally, a senior hydrographer reviews the record and makes any required changes. Records for one-third of the stations are earmarked for formal review by another field office within the WAWSC or outside the WAWSC. Thus, records for all stations should receive an outside review about once every 3 years. The goal of the review is to 
ensure that proper methods were applied throughout the process of obtaining the surface-water data and computing the record. A key element for a quality-assurance plan is ensuring the thoroughness, consistency, and accuracy of streamflow records. These records comprise various data, which include the gage-height record including instantaneous extremes, levels, ratings, datum and gage-height corrections, shifts, hydrographs, station analyses, winter records, furnished records, and instantaneous and daily-mean values of discharge. The goals, procedures, and policies for each component differ.

\section{Gage Height}

The accuracy of surface-water discharge records depends on the accuracy of discharge measurements, the accuracy of rating definition, and the completeness and accuracy of the gage-height record (OSW Technical Memorandum 93.07). Computation of streamflow records includes ensuring the accuracy of gage-height records by comparisons of gage-height readings made from independent reference gages, and comparisons of readings from made from reference and auxiliary gages. The accuracy of the extreme gage-height recordings are verified by the examination of high-water marks, comparisons of the redundant recordings of peaks and troughs by use of maximum and minimum indicators, and the examination of data obtained at CSGs. Accuracy of the gage heights also are confirmed with the maintenance of gage datums through station levels.

Hydrographers examine the gage-height record to determine if the record accurately represents the water level of the body of water being monitored. As part of this examination, they identify periods of time during which inaccuracies have occurred and, whenever possible, determine the cause for those inaccuracies. When possible and appropriate, personnel correct an inaccurate gage-height record and place notes to that effect in the primary station folder. When corrections are not possible, hydrographers should remove the erroneous gage-height data from the set of data used for computation of streamflow records to avoid possible misunderstanding and misuse of the flawed data. When they delete erroneous data, hydrographers document this action, including their reasoning for deleting the data, on the station analysis included in the primary station folder.

Documentation of gage-height records involves detailing observations in several parts of the record to clearly document stage changes at the station. Hydrographers must document all gage-height corrections by entering them in the computer and, optionally, including a hard copy of the file in the primary folder. They should note gage heights observed during field inspections or discharge measurements directly on the primary record on the day of observation to assure agreement between the observed and computed gage heights. Additionally, hydrographers should note the source of gage-height data used to fill in periods of missing or erroneous gage-height data on the primary record sheet as well as on the station analysis within the primary station folder. Generally, the person assigned to the station will be the one who deletes or inserts backup data in the computer files. The hydrographer keeps electronic copies of backup EDL data in the archive under the EDL directory (appendixes C and E).

\section{Discharge Ratings}

One of the principal tasks in computing the discharge record is the development of the stagedischarge relation, also referred to as the rating. The rating is usually the relation between gage height and discharge (simple rating). Ratings for some special sites involve additional factors such as stagearea and index-velocity relations, rate of change in stage or fall in slope reach (complex ratings) (Kennedy, 1983, p. 14). WAWSC personnel follow procedures for the development, modification, and application of ratings that are described in Kennedy (1984). WAWSC personnel also follow guidelines pertaining to rating and records computation that are presented in Kennedy (1983, p. 14), Levesque and Oberg (2012), and in Rantz and others (1982, chaps. 10-14 and p. 549). 
For each gaging station, the most recent digital rating table can be obtained by accessing the rating table files in the computer using ADAPS. Additionally, the hydrographer may maintain a paper copy of the rating table in the station primary folder and in the field folder. A graphical plot of the most recent rating can be obtained by using either ADAPS or the Graphical Rating and Shift Application Tool to plot the rating, in the swreview directory (appendix C), or by accessing the original paper version or copy in the station primary folder, copies in the field folder, or through AutoFF.

Various WAWSC procedures apply to ratings. Typically, the hydrographer assigned to the station develops new ratings; however, sometimes a reviewer or checker of the first records computation develops the new rating. Hydrographers obtain in-house reviews of ratings and shifts before they are distributed outside the office. Final ratings are approved by the Field Office Chief. Hydrographers generally apply shifts to the rating when measurements indicate a change in the rating or previous shift. The need for a new shift takes into consideration the quality of the discharge measurements that define the shift. New shifts are needed if (1) the discharge of excellent or good rated measurements are more than 5 percent different from the computed discharge with the current rating and current shifts, (2) fair rated measurements are more than 8 percent different, and (3) poor-rated measurements are more than 10 percent different (poor-rated measurements have errors greater than 10 percent and need to be considered on a case-by-case basis). Shifts that extend over the entire range of the rating and (or) persist more than 1 year may indicate a fairly stable control change and should be analyzed and a new rating should be created. Ratings generally should be extended to no more than twice the discharge of the highest direct measurement and not beyond the gage height of likely control changes. Hydrographers should include all measurements made to develop the new rating, along with the highest 10 measurements made at the site. The old rating should be included on the same sheet as the new rating. Sheets showing the new and old ratings should show the numbers of the ratings and the dates they were first applied and ended, station name and number, measurement numbers (if practical), the offset(s), and values for the x- and y-axes (discharge and stage). The Field Office Chief, Data Chief, Surface-Water Specialist, or Hydroacoustics Specialist provides the ultimate guidance to WAWSC personnel regarding ratings.

\section{Datum Corrections, Gage-Height Corrections, and Shifts}

Datum corrections, as measured by levels, represent a correction applied to gage-height readings to compensate for the effect of settlement or uplift of the gage (Kennedy, 1983, p. 9). Hydrographers apply datum corrections to gage-height record in terms of magnitude (in feet) and in terms of when the datum change occurred. In the absence of any evidence indicating exactly when the change occurred, hydrographers must assume that the change occurred gradually from the time the previous levels were run, and they prorate the correction with time (Rantz and others, 1982, p. 545). This may require records revision for previous years. Datum corrections apply when the magnitude of the vertical change becomes greater than $0.02 \mathrm{ft}$.

Gage-height corrections compensate for differences between the primary gage and the reference gage (Rantz and others, 1982, p. 563). These corrections apply in the same manner as datum corrections. Hydrographers apply gage-height corrections to make recorded data agree with referencegage data. They apply these corrections when the difference between the primary (recording) gage and the reference gage is greater than $0.02 \mathrm{ft}$.

A shift represents a correction applied to the stage-discharge relation, or rating, to compensate for a physical change in the hydraulic control, such as formation or erosion of a transient sand bar or other channel feature. Shifts indicate the fact that stage-discharge relations are not permanent but vary from time to time, either gradually or abruptly, because of changes in the physical features that form the control at the gaging station (Rantz and others, 1982, p. 344). Applied shifts vary in magnitude with 
time and with stage (Kennedy, 1983, p. 35). Generally, hydrographers do not apply shifts unless a measurement, or series of measurements, varies more than estimated accuracy of the discharge measurements from the rating. A stage-shift diagram documents shifts, plotting a measurement's shift from the rating against the measurement's gage height. The base rating itself shows as the zero shift line. Using evidence from the hydrograph, rating, and plotted measurements determines how the shift diagram is drawn and applied. In the WAWSC, time shifts normally are used only when a stage shift cannot be justified by the available data. For some streams with very mobile bed material, time shifts may be more appropriate for working the record. Once shifts are applied, measurements should vary from the rating by less than the quality of the discharge measurements.

The hydrographer documents datum and gage-height corrections, and shifts in the computer, station files, and station analysis. Datum and gage-height corrections and shift data in the computer are located in the ADAPS system files and in the swreview directory. Generally, transitions in gage-height corrections and shifts should be smooth between periods of computation. If an obvious error is detected while reviewing a period of computation, the error is corrected and the data are recomputed. However, if the perceived error is simply a difference of opinion in the processing the record - that is, when to apply the shift, what stages the shift should be applied, etc. - the general rule is to make no change to the record in a computation period if the discharge difference is less than 5 percent.

\section{Hydrographs}

A daily discharge hydrograph is a plot of daily mean discharges compared to time. The horizontal axis represents the date, and the logarithmic vertical axis represents the discharge. In the process of computing station records, this hydrograph becomes a useful tool for identifying periods of erroneous information, such as incorrect shifts or datum corrections. Additionally, hydrographs help estimate discharges for periods of undefined stage-discharge relation, such as during backwater or ice conditions, and help estimate discharges for periods of missing record.

Information placed on the hydrograph for each station includes station name, station number, water year, date the hydrograph was plotted, drainage area, plot of daily mean discharge data, plots of measurements, and hydrograph(s) of the streamflow station(s) with which the hydrograph was compared. Climatological data, such as daily precipitation totals and maximum and minimum air temperatures, sometimes are included on a hydrograph to help evaluate the validity of the discharges. Personnel generally create the hydrograph in ADAPS and may print it out on a plotter. Reviewers check and finalize hydrographs during the second computation or final review.

Hydrographic comparison helps verify the reasonableness of the computed discharge data.

Station sites that are the most appropriate for hydrographic comparison are sites that are downstream or upstream of the station being analyzed, sites in adjacent watersheds, or sites with comparable drainage areas in the same general vicinity. Comparisons also can be made by adding or subtracting stations, which is useful for streams with diversions. Large differences noted by the hydrographic comparison can be an indication that the records for one or both stations have been misinterpreted. Regardless, large differences need to be explained and included with the hydrograph as part of the review package. Final hydrographs with comparison sites should become part of the annual archived file when an adequate electronic copy is not available.

\section{Station Analysis}

The station analysis documents for each station, where data are collected, the procedures used in processing the data, and the logic upon which the computations were based for the analysis period. The analysis serves as a basis for review and as a reference in case questions arise about the records at some future date (Rantz and others, 1982, p. 580). Topics discussed in detail in the station analysis include 
equipment, hydrologic conditions, gage-height record, data corrections, rating, discharge measurements, special computations, remarks, and recommendations. The section on gage-height record includes information on instrument issues and maximum and minimum recorded stages and other means of required independent verification used to verify those extremes (OSW Technical Memorandum 2014.06). The section on datum corrections provides information on levels and the gage datum. The rating section details the control conditions for the gage, type of bed material, rating and shifts used during the analysis, and maximum and minimum computed discharges (recorded and verified values). The discharge section provides information and discussion of the rating and hydrographic comparison used. Finally, the remarks section details record accuracy and miscellaneous information on the station record, such as rating irregularities, estimated record, assumptions and (or) reasoning needed to interpret the record, or recommendations for station operation and maintenance. The hydrographer responsible for maintaining the station generally writes the station analysis. If the analysis period ends on or crosses the end of the water year, an additional "Water Year Summary" section is added to the analysis that summarizes the discharge measurements, range in discharge, maximum and minimum gage heights and how they were verified, a listing of the hydrographic comparisons, a listing of any missing or estimated record, and the quality of the record. Once an analysis for a period that has crossed the end of the water year has been finalized, it is the responsibility of the hydrographer who writes the station analysis to provide a list of all the peaks above base to the database administrator so that they can be added to the Peak-Flow File.

The WAWSC maintains electronic files for all station analyses. These files for data through September 2010 are stored on a WAWSC server, IIgs $\backslash$ tacomawa-w\Data\WAWSC_document_archives\analysis. For data starting after September 2010, station analyses are stored in the USGS Records Management System (RMS). Hydrographers create station analysis files in RMS, which is accessible through the WAWSC internal Web page. The station analysis for each analysis period becomes part of the final archived records.

\section{Continuous Records Processing}

USGS Water Mission Area policy requires Continuous Records Processing (CRP) of all water time-series data (see WRD Policy Memorandum no. 2010.02). CRP is the collection, analysis, review, and approval of time-series hydrologic data on a sub-water year basis. In accordance with policy requirements, the WAWSC has grouped its sites into the three CRP categories following the criteria described in Attachment 1 of WRD Policy Memorandum no. 2010.02:

- Category 1 sites are approved and finalized in NWIS within 150 days of the date of collection.

- Category 2 sites are approved and finalized in NWIS within 240 days of collection.

- Category 3 sites are special cases where CRP does not apply.

There is a three-step process of working the records, checking the records, and reviewing the records prior to approving the records. Records are worked by the hydrographer responsible for the station and then checked by another assigned hydrographer; finally, reviews are made by senior hydrographers. The progress and status of CRP records are tracked in the Records Management System (RMS). Hydrographers are assigned records to check and review in RMS and are notified by an automated email when a record is ready for the next step of the process. RMS cannot approve records. Records are approved through the record data aging status in ADAPS. If records are ready for approval, the final reviewer approves the record in ADAPS. This step locks the record to prevent it from being changed. The WAWSC CRP goals for all categories of surface-water records are 50, 65, and 80 percent compliance in Fiscal Years 2014, 2015, and 2016, respectively. 
A paperless process has been developed for the working, checking, and reviewing records that uses the output from swreview and a set directory structure (appendix E). The hydrographer who compiles the record for the current analysis period creates a new directory under "Record_Review" that is named for the type of computation being made, such as "Discharge" for discharge computations or "TDG" for total dissolved gas computations. Under this directory, a directory is created with a name that is the period of analysis in a YYYYMMDD-YYYYMMDD format, for example "2013100120140203" for the analysis period from October 1, 2013, to February 3, 2014. The hydrographer who works the record will run swreview for the analysis period and copy all the swreview files to a directory referred to as "SWR1_worked." The hydrographer working the record completes the CRP Streamflow Checklist (available on the Hydrologic Data Program internal Web page) that would have the following filename for an example site with station number 12083000, "12083000.CRP.RecordsChecklist.pdf," and it would be located in the period of analysis directory. Additional files (if needed) that are pertinent to the analysis period also are placed in this directory. Files that are not tied to a specific period of analysis, such as the Datum/Gage-Height-Corrections Template.xlsx (available on the Hydrologic Data Program internal Web page), are placed to the Discharge directory. For our example, this file would be named "Datum-G.H.Corrections12083000." The swreview files are all pdf-formatted files and can be marked with comment boxes or inserted text as needed to show the reviewers that the data have been checked or other additional information that may be needed. Special markups of the swreview files should be noted in the comment section of the CRP Streamflow Checklist file. RMS is used for the station analysis and, once it is completed, the review process continues with the checker. The checker uses the same CRP Streamflow Checklist file to note their review steps and comments. If the checker makes any changes to the record or to any of the swreview files, a new directory is created under the period of analysis directory, referred to as "SWR2_checked," where new swreview files are stored. Finally, the reviewer does the final review with the same CRP Streamflow Checklist file before locking the file as approved. As with the checker, if changes are made to the record or swreview files, a new directory is created (referred to as "SWR3_reviewed") where new swreview documents generated by the reviewer are stored.

Communication is a key element in the working, processing, and reviewing of records. The WAWSC encourages hydrographers performing the second computation in the record check and review process to discuss all changes made to the record with hydrographers performing the first computations. Such interaction educates hydrographers performing first computations about errors they may have made in procedure or analysis, and also enables them to knowledgeably discuss any changes made to the record with future reviewers. The Field Office Chief or the person with the delegated authority makes the final decision if differences of opinion cannot be resolved between the hydrographers performing the first and second computations. The final reviewer assures that the station analyses are properly completed and stored in RMS.

\section{Winter Records}

Computing records that represent winter periods for gaging stations sometimes involves procedures that are not applicable to records that represent other times of the year. The formation of ice in stream channels or on section controls affects the stage-discharge relation by causing backwater; the effect varies with the quantity and nature of the ice, as well as with the discharge (Rantz and others, 1982, p. 360). During some ice conditions, the recorded gage-height data may be accurate, although the actual stage-discharge relation may be undeterminable and unstable. An example of this condition would be when surface ice forms on the stream, but the stilling well remains unfrozen and the water level in the stilling well represents the backpressure caused by ice in the channel. During other conditions, the recorded gage-height data are inaccurate, resulting in periods of missing gage-height 
record. An example of the latter conditions would be when a stilling well or the intakes to the stilling well freeze.

Ice-affected records usually are only an issue for field offices in eastern Washington. The hydrographer computing the station record identifies ice-affected periods from weather records and hydrographic comparisons, and estimates discharge based on measurements made at the site during ice conditions or on hydrographic comparisons with nearby stations unaffected by ice. Generally, iceaffected gage-height records are not considered erroneous and the data are not removed from the computer files. Hydrographers process their own data for ice-affected conditions.

\section{Furnished Records}

The WAWSC receives surface-water data collected under the supervision of other agencies, organizations, or institutions. The WAWSC performs quality assurance on these data, publishes the data online using NWISWeb, and archives the data in NWIS. Data collected through September 2013 were published in the USGS Annual Data Report for Washington State. The quality-assurance program for data collection includes at least two annual check measurements and gage inspections. The qualityassurance program for the furnished data, which includes mean daily discharge values and extreme stages and discharges, involves, at minimum, biannual records reviews. These reviews include checking the daily values summary, list of discharge measurements, copies of the front sheets for the discharge measurements, primary computation sheets showing gage-height and datum corrections and shifts, a hydrograph and hydrographic comparison with another station, rating tables and rating curves, shift diagrams, and the station analysis. If the USGS computer system receives real-time data from the furnished-record station, then the real-time computations in ADAPS also will provide part of the quality-assurance check. In these cases, the WAWSC strives to minimize computed data differences by having the agency furnishing the record work from the same electronic dataset as the one received in real time by the USGS computer system. In the case of errors in computation of the furnished record or questions regarding the standards under which the data were collected, the USGS will work with the furnishing agency to resolve these issues. In cases where the issues cannot be resolved, or the record is determined to be unreliable, the record should not be published. Documentation of the issues in these cases should be made part of the station record, and the USGS should work with the furnishing agency to remedy the situation.

\section{Daily Values Table}

With few exceptions, for each gaging station operated by the USGS, ADAPS computes and stores a mean discharge value for each day. The daily values table generated by ADAPS displays mean daily discharges for the water year. Hydrographers compare the table of daily discharge values with hydrographs to ensure reasonableness and accuracy of the tables. .

\section{Publication of Data}

For data collected through September 2013, once WAWSC personnel computed, analyzed, checked, reviewed, and finalized records for the water year, the surface-water data for that water year were published, along with other data, in the USGS Annual Water Data Report. Information presented in the annual data report included daily discharge values during the year, extremes for the year and period of record, and various statistics. Additionally, station-description information presented in the annual data report supplied important details such as physical descriptions of the gage and basin, history of the station and data, and statements of cooperation. In preparing data for publication the WAWSC followed the guidelines presented in the report, "WRD Data Reports Preparation Guide" (Novak, 1985). 
For data collected after September 2013, the procedures remain essentially the same, except that data are no longer published in a USGS Annual Water Data Report. Instead, data are computed, analyzed, checked, reviewed, and finalized on an ongoing basis, and are considered published when they are posted online using NWISWeb and labeled "approved." A subset of the ancillary information included in the historical annual data reports, such as extremes for the period of record, various statistics, and other information, is currently (2014) available online through user options in NWISWeb. The USGS is in the process of developing new user options for requesting additional ancillary information.

\section{Crest-Stage Gages}

In the WAWSC, CSGs frequently are installed near recording gages, especially those where pressure transducers or radar gages are used, to document and provide an independent verification of the recorded peak stages as described in the section, "Gage Height." CSGs also are used independently at CSG sites to compute a time series of annual peak discharges using an initial stage-discharge relation, or rating, developed for the site by direct or indirect high-water measurements. The rating is verified or adjusted on the basis of subsequent direct or indirect high-water measurements.

Procedures for computing discharge records at CSG sites should be similar to those for other gaging stations. The field notes are examined for correctness and accuracy. Peak stages recorded by CSGs are cross-referenced with other available information; the dates of the peaks are determined by analyzing available precipitation data and peak data from recording gages within the same basin or from nearby basins. For each CSG site, a list of all measurements with their assigned chronological number is maintained in SiteVisit, and a plot of the current rating, along with each recent and each notably high stage-discharge measurement, is made available to those who check and review the station record. The original graphical rating plots are kept in the station folder. Current station descriptions and a summary of levels for CSG sites are maintained in SIMS and SLAP.

A brief station analysis is entered into SIMS during each analysis period. When an analysis period crosses the end of a water year, a water-year summary paragraph is included in the analysis describing the computation of the annual peak, identifying which rating was used and the type of flow condition, and describing how the dates of the peaks were determined. The hydrographer in charge of the station is responsible for providing the data-base administrator with the annual peak so that the Peak-Flow File can be updated promptly after peak data have been finalized. A current listing of annual peaks becomes part of the station folder for review purposes (OSW Technical Memorandum 88.07).

\section{Real-Time Data}

\section{Processing of Real-Time Streamflow Data}

A necessary and critical element in maintaining accurate streamflow records on a real-time basis is the need for rating analysis and shift application as soon as practicable after a discharge measurement has been made. Generally, the hydrographer updates shifts or ratings within 1 week after the completion of a field trip. In certain situations, Field Office Chiefs may ask that information from discharge measurements be called in immediately from the field and input by office staff. This may be required during floods if shifts are likely to have a significant effect on peak flows, with special consideration given to sites that serve as National Weather Service flood forecast points. Data from sites that are critical to water management agencies for their daily operational requirements also may require more stringent measurement review and shift-application procedures.

During floods, the Field Office Chief will decide how to allocate resources for making discharge measurements or making field repairs to get telemetry functioning at critical stations. 


\section{Internet Presentation of Streamflow Data}

WAWSC real-time and other data are stored in the WAWCS local NWIS database. These data are transferred to the national NWISWeb system for public internet display and are available on the WAWSC Web site at http://wa.water.usgs.gov/data/realtime/. NWIS-RT, the national real-time backup system, is enabled during extended local system outages.

The WAWSC real-time data Web site is maintained by the WAWSC surface-water database administrator (DBA). The Data Chief reviews and approves changes in the Web site design and contents with input from the DBA and WAWSC Web Advisory Committee.

\section{Review of Real-Time Streamflow Data}

Real-time streamflow data that are disseminated on the public Web site are reviewed frequently to ensure their quality and to prevent the distribution of erroneous information. The WAWSC uses both automated and manual review procedures to meet this objective.

To prevent erroneous spikes from appearing on NWISWeb, the hydrographer must enter thresholds in ADAPS (Water Resources Division Policy Memorandum 99.34). At a minimum, the Very-high-value and Very-low-value must be set in ADAPS for every station for which NWISWeb displays real-time data. NWISWeb automatically checks all DCP stations for the occurrence of very high or very low stage or discharge values to detect probable erroneous data and notifies the WAWSC if a spike is detected. An automated system implemented by the WAWSC informs designated field office personnel if a DCP station has failed to transmit data after 8 hours.

In addition to using automated reviews of data, hydrographers review data displayed on the internet for accuracy and (or) missing data at least daily during normal business hours.

\section{Error Handling}

There are two general types of errors associated with streamflow data that are disseminated in near-real-time on the internet. The first type involves persistent problems usually associated with some type of equipment failure, whether in data collection or transmission, but these problems also could be related to ice effects. These types of problems generally occur on a continuing basis for more than a single recording interval. The second type involves intermittent problems, which frequently are the result of a data transmission error. These problems usually manifest themselves as data values that are either zero or unreasonably large. Hydrographers use the hydrographs displayed by NWISWeb to determine if instruments are working correctly. Upon discovery, hydrographers fix the problem and seek assistance from the Database Administrator, Field Office Chief, or Data Chief, as needed.

\section{Data Qualification Statements}

Streamflow data made available on the internet are considered provisional until the formal review process has been completed. To ensure that everyone who accesses data from the internet is aware of this, data-qualification statements are included at key locations with a clickable disclaimer on all real-time data pages. The disclaimer is located at the URL http://wa.water.usgs.gov/realtime/disclaimer.html. 


\section{Office Setting}

Maintaining surface-water data and related information in a systematic and organized manner and in predominantly electronic format increases the efficiency and effectiveness of data-analysis and data-dissemination efforts. Good organization of both electronic and paper files reduces the likelihood of misplaced or overlooked information. Procedures for maintaining surface-water records in each of the four WAWSC field offices are nearly the same, although some differences exist.

\section{Work Plan}

Field Office Chiefs regularly communicate work assignments verbally to their staff. Each hydrographer is assigned a set of gaging stations by their respective Field Office Chief. The USGS Records Management System (RMS) is used to track the status of computations for those stations.

The construction crew based in Tacoma performs most of the major gage-construction duties in the WAWSC. Occasionally, a contractor installs a cableway system at a new gage. Minor or routine gage maintenance and installation usually remain the responsibility of the hydrographer assigned to the gage.

\section{File Folders for Surface-Water Stations}

Hard-copy files in each field office include a separate set of folders for each gaging station, organized by station number in downstream order. Separate folders for current water-year data and previous water-year data, as well as gaging-station history and special studies such as recent indirect measurements, are kept in one main station folder. Extraneous items are removed from the current files after records are finalized each year. At the discretion of the Field Office Chief, hard copies of the station review items may be filed in the station review folders or may be stored only electronically in the Data directory as outlined in the section, "Station Analysis." Station review folders generally contain the final data for the most recent 3 years of record. The data for each water year may include the mean daily and extreme discharge sheet, hydrograph, station analysis, station manuscript, measurements list, datum correction values, variable shift values, stage-discharge rating-shift analysis, summary of extreme events, shift diagrams, annual statistics, station description, surface-water review notes, and any other pertinent items.

The set of current files varies for each station. For all stations, a current-year folder holds all hard-copy measurement notes, preliminary hard copies of primary-records computations, shift diagrams, ratings, datum and gage-height correction notes, and other current-year information. The technical folder may contain continuously updated information such as the station analysis, historical list of measurements, the station description, station statistics, and level notes, as well as items such as memorandums to the record, letters regarding the station, access information, old ratings, maps, photographs, cableway inspection forms, and any historical data or information on the gage. Another folder contains any indirect measurements that have been made at the site.

Historical records are filed in various ways. Past-year primary-record files are fastened together and stored by year in a designated area. Measurement notes, indirect-measurement analyses, and CSG records are kept in historical files for each type of data and are filed by station number. Records older than about 15 years should be archived appropriately, and records of their archival and whereabouts should be maintained in the station folder. 


\section{Field-Trip Folders}

Paper field trip folders are no longer used in the WAWSC. The information that was traditionally kept in these folders is electronically available to the hydrographers on their PDA, laptop, or tablet with the AutoFF program. The hydrographers are responsible for loading the most recent files onto the electronic device that they will be taking with them to the field. The primary purpose of the files in AutoFF is to provide driving logs, maps, station descriptions, station lists, traffic control plans, and other pertinent information to allow field personnel to run the trips effectively at a moment's notice and with a minimum of time spent on last-minute preparations.

\section{Levels}

Hydrographers are required to use the Station Levels computer program in the field to log their level field notes. If one has to use paper level notes, they are filed in a central file. These data are not archived, but are maintained in the files for the period of record of the station. All stations, current and discontinued, are included. Files are organized by station number in downstream order. Electronic level notes and level summaries are maintained in the Station directory under the sub directory, "Levels," (see appendixes $\mathrm{C}$ and E). A second copy of level peg tests is stored in the Data $\backslash$ field office] $\backslash$ documents $\backslash$ Peg Tests directory (appendix C). Level summaries also are available in SIMS through the SLAP (Site Levels Archiving and Processing) application.

\section{Station Analyses and Descriptions}

The most recent station analysis and station description files are present in RMS and in the Site Information Management System (SIMS), respectively, which are available through the WAWSC internal Web page. Hydrographers include electronic copies of the station descriptions in AutoFF under the station directory. Current water-year files may contain copies of the station analysis of the previous year. Historical station analyses become part of the archived data.

\section{Discontinued Stations}

The WAWSC has no special treatment for files from discontinued stations. Annual data from these stations are filed with data from the same year for other stations. Measurements are filed by station number with other stations, current or otherwise, in the WAWSC measurement files.

\section{Map Files}

The WAWSC maintains hard-copy files for USGS maps of Washington. Map scales include 1:100,000, 1:250,000, 1:24,000 (7.5 min. series), and 1:62,500 (15 min. series). The WAWSC files the 1:100,000 and 1:250,000 maps in separate drawers, and files the 1:24,000 and 1:62,500 maps in alphabetical order by map title in a series of drawers. Any of these maps can be marked on and used as work maps. The Upper Columbia Field Office also maintains a set of Washington State topographic maps.

Geospatial files in Adobe pdf format are available for of all the 1:24,000 (7.5-minute series) maps in the State of Washington. The maps are available from the WAWSC server at $\backslash$ gs $\backslash$ tacomawaw $\backslash$ Resources $\backslash$ WA_GIS $\backslash$ topo_quads_pdfs-. The pdf file named 24K_Wa.pdf is an index map for the State of Washington. 


\section{Archiving}

The USGS has adopted policies for the management and retention of hydrologic data (Water Resources Division Memorandum 92.5). Selected material not maintained in field offices is placed in archival storage. In the WAWSC, the WAWSC Administrative Services Section maintains detailed information on which records have been sent to archival centers. This information includes detailed letters of transmittal and accession numbers, so that the data can be retrieved when needed. Data targeted for archives include, but are not limited to, original data and edited data, observer's notes and readings, station descriptions, analyses, and other supporting information (Water Resources Division Memorandum 92.5; Hubbard, 1992, p. 12).

Electronic data are filed in the appropriate directory under the Data directory (appendixes $\mathrm{C}$ and E) and then annually archived by the WAWSC Informational Technology (IT) Section on Linear Tape Open 3 and DVDs in two locations. All basic DCP data (gage height, discharge, and precipitation, for example) including back-up records are permanently stored in NWIS, whereas DCP performance data are kept for only 180 days and then deleted.

The WAWSC sends surface-water information from the field offices to the Federal Records Center (FRC) every 7-10 years, on average. In the WAWSC, the Sand Point FRC in Seattle stores original surface-water data. The Field Office Chiefs decide which information is sent to the FRC and when that information is sent. The Administrative Services Section ensures that the information is properly packed and logged, and ascertains that the information is received by the FRC. In their office files, the Administrative Services Section maintains records of exactly what has been archived. For the Western Washington Field Office (WWFO), these data include original discharge measurements for all stations prior to 1994, primary sheets, gage-height books, rating tables, and observer notebooks and cards. For discharge measurements made since 1994, all level and snow-survey paper notes for the WWFO are maintained in files on-site. The Upper Columbia and Mid-Columbia Field Offices retain all original measurement paper notes on site. Electronic notes and data are archived in specific directories (appendixes $\mathrm{C}$ and $\mathrm{E}$ ), and these directories are archived annually by the WAWSC's IT Section. Personnel who have questions concerning archiving procedures should address their questions to the Data Chief. Personnel who receive requests for information that require accessing archived records should contact the WAWSC Outreach Coordinator and (or) the Administrative Services Section for guidance on obtaining the records.

Project Chiefs ensure that surface-water data collected as part of investigative studies are appropriately archived. WAWSC policy requires that surface-water data collected for investigative studies be archived within 2 years after completion of the studies. However, all time-series surfacewater data should be included in the appropriate field-office files. Project-related streamflow data incorporated in ADAPS that are published online are archived with other stations from the Washington field offices. However, it remains the responsibility of the Project Chief to coordinate with the field offices for proper archival and storage of streamflow measurements, indirect measurements, and other original data. Archiving procedures for specialized surface-water data, such as drainage-area delineations, rainfall-runoff models, other hydrologic models, or related information such as evapotranspiration, depend on programs set up by the Project Chief and the WAWSC IT Section. The IT Services Section archives all electronic data provided by Project Chiefs on two copies of LT03 tapes, and on DVDs where it is stored and retrievable. 


\section{Publication of Surface-Water Data}

Surface-water data collected after September 2013 are no longer published in the USGS Annual Water Data Report. Instead, the data are computed, analyzed, checked, reviewed, and finalized on an ongoing basis and are considered published when they are posted online using NWISWeb and labeled "approved."

The WAWSC follows USGS Fundamental Science Practices (http://www.usgs.gov/fsp/) in its publication of surface-water data, including publication of these data in USGS series reports or other publications as part of investigative studies. For interpretive reports, this process requires at least two technical reviews of publications and final approval by the Bureau Approving Official of the USGS.

\section{Safety}

Performing work activities in a manner that ensures the safety of personnel and others remains the highest priority for the USGS and the WAWSC. Beyond the obvious negative effects unsafe conditions can have on personnel, such as accidents and personal injuries, they also can have a direct effect on the quality of surface-water data and data analysis. For example, errors may be made when an individual's attention to detail is compromised when dangerous conditions create distractions. To ensure that personnel are aware of, and follow, established procedures and policies that promote all aspects of safety, the WAWSC communicates information and directives related to safety to all personnel through in-house and out-of-office training classes, memorandums, online training, and other methods.

In the WAWSC, a designated collateral duty Safety Officer heads the WAWSC Safety Committee, identifies and provides direction on safety issues, manages the safety budget, coordinates safety training, prepares safety reports for the Regional Safety Officer, and addresses new and ongoing safety issues. The USGS provides policy and guidelines for safety-related issues in the WAWSC. The WAWSC Safety Committee, which meets periodically, consists of 13 members:

- The WAWSC Safety Officer,

- The WAWSC Director,

- The Data Chief,

- One member from each of the four field offices,

- One member from each of the three Studies Sections,

- A Chemical Hygiene Officer,

- A member of the Administrative Services or IT Sections, and

- The Aviation Safety Coordinator.

The WAWSC Safety Committee membership and Charter are on the WAWSC internal Web page. Personnel who have questions or concerns pertaining to safety, or who have suggestions for improving some aspects of safety, should direct those questions, concerns, and suggestions to their supervisors or the WAWSC Safety Officer. 


\section{Training}

Ensuring that personnel obtain knowledge of correct methods and procedures is a vital aspect of maintaining the quality of surface-water data collection and analysis. By providing appropriate training to personnel, the WAWSC increases the quality of work and eliminates the source of many potential errors.

In-house and out-of-office training classes and other learning opportunities supplement the work experience and self-training of the hydrographers. Such training teaches skills unfamiliar to the hydrographers or improves their underdeveloped skills. The Field Office Chief suggests appropriate training with input from the hydrographers and provides applicable training opportunities. Options for USGS training classes and suggested training schedules are available at the following internal USGS Web pages: http://water.usgs.gov/usgs/osw/training.html and http://water.usgs.gov/usgs/STED/. Additionally, options for hydroacoustics training are available at the public USGS Web site (http://hydroacoustics.usgs.gov/training/register.shtml), and webinars and podcasts are available to keep staff current on new hydroacoustic policies and techniques.

\section{Summary}

Information included in this quality-assurance plan documents the policies and procedures of the Washington Water Science Center (WAWSC) that ensure high quality in the collection, processing, storage, analysis, and publication of surface-water data. Specific types of surface-water data discussed in this report include stage and streamflow data. The roles and responsibilities of WAWSC personnel for carrying out these policies and procedures are presented. Additionally, the plan discusses management of the database, including real-time data, and employee safety and training. In the WAWSC, hydrographers are responsible for operating and maintaining their assigned surface-water stations and working with their fellow employees in a team effort to assure high-quality data collection, analyses, reviews, and reports for partner agencies and the general public.

\section{Acknowledgments}

The author wishes to acknowledge the good work by Dave Kresch (USGS-retired) and Stewart Tomlinson (USGS-retired) for building the foundation for this report.

\section{References Cited}

Arcement, G.J., and Schneider, V.R., 1989, Guide for selecting Manning's roughness coefficients for natural channels and flood plains: U.S. Geological Survey Water-Supply Paper 2339, 38 p.

Arvin, D.V., 1995, A workbook for preparing surface-water quality-assurance plans for districts of the U.S. Geological Survey, Water Resources Division: U.S. Geological Survey Open-File Report 94$382,87 \mathrm{p}$.

Barnes, H.B., 1967, Roughness characteristics of natural channels: U.S. Geological Survey WaterSupply Paper 1849, $213 \mathrm{p}$.

Benson, M.A., and Dalrymple, Tate, 1967, General field and office procedures for indirect discharge measurements: U.S. Geological Survey Techniques of Water-Resources Investigations, book 3, chap. $\mathrm{A} 1,30 \mathrm{p}$.

Bodhaine, G.L., 1982, Measurement of peak discharge at culverts by indirect methods: U.S. Geological Survey Techniques of Water-Resources Investigations, book 3, chap. A3, $60 \mathrm{p}$.

Buchanan, T.J., and Somers, W.P., 1969, Discharge measurements at gaging stations: U.S. Geological Survey Techniques of Water-Resources Investigations, book 3, chap. A8, 65 p. 
Campbell, P., 2014, Standard operating procedures for under-ice discharge measurements using ADCPs: Water Survey of Canada, version 1.1, 38 p.

Carter, R.W., and Davidian, Jacob, 1968, General procedures for gaging streams: U.S. Geological Survey Techniques of Water-Resources Investigations, book 3, chap. A6, 13 p.

Dalrymple, Tate, and Benson, M.A., 1967, Measurement of peak discharge by the slope-area method: U.S. Geological Survey Techniques of Water-Resources Investigations, book 3, chap. A2, 12 p.

Davidian, Jacob, 1984, Computation of water-surface profiles in open channels: U.S. Geological Survey Techniques of Water-Resources Investigations, book 3, chap. A15, 48 p.

Edwards, T.K., and Glysson, G.D., 1988, Field methods for measurement of fluvial sediment: U.S. Geological Survey Open-File Report 86-531, 118 p.

Fulford, J.M., 1994, User's guide to SAC, a computer program for computing discharge by the slopearea method: U.S. Geological Survey Open-File Report 94-360, 31 p.

Fulford, J.M., 1995, User's guide to the culvert analysis program: U.S. Geological Survey Open-File Report 95-137, 69 p.

Hubbard, E.F., 1992, Policy recommendations for management and retention of hydrologic data of the U.S. Geological Survey: U.S. Geological Survey Open-File Report 92-56, 32 p.

Jarrett, R.D., and Petsch, H.E., Jr., 1985, Computer program NCALC user's manual-Verification of Manning's roughness coefficient in channels: U.S. Geological Survey Water-Resources Investigations Report 85-4317, 27 p.

Kennedy, E.J., 1983, Computation of continuous records of streamflow: U.S. Geological Survey Techniques of Water-Resources Investigations, book 3, chap. A13, 53 p.

Kennedy, E.J., 1984, Discharge ratings at gaging stations: U.S. Geological Survey Techniques of WaterResources Investigations, book 3, chap. A10, 59 p.

Kenney, T.A., 2010, Levels at gaging station: U.S. Geological Survey Techniques and Methods, book 3, chap. A19, 60p.

Kilpatrick, F.A., and Schneider, V.R., 1983, Use of flumes in measuring discharge: U.S. Geological Survey Techniques of Water-Resources Investigations, book 3, chap. A14, $46 \mathrm{p}$.

Kresch, D.L., and Tomlinson, S.A., 2004, Surface-water quality-assurance plan for the U.S. Geological Survey Washington Water Science Center: U.S. Geological Survey Open-File Report 03-490, 50 p.

Levesque, V.A., and Oberg, K.A., 2012, Computing discharge using the index velocity methods: U.S. Geological Survey Techniques and Methods, book 3, chap. A23, 148p.

Matthai, H.F., 1967, Measurement of peak discharge at width contractions by indirect methods: U.S. Geological Survey Techniques of Water-Resources Investigations, book 3, chap. A4, 44 p.

Mueller, D.S., Wagner, C.R., Rehmel, M.S., Oberg, K.A., and Rainville, Francois, 2013, Measuring discharge with acoustic Doppler current profilers from a moving boat (ver. 2.0, December 2013): U.S. Geological Survey Techniques and Methods, book 3, chap. A22, 95 p. [Also available at http://pubs..usgs.gov/tm/3a22.]

Novak, C.E., 1985, WRD data reports preparation guide: U.S. Geological Survey Open-File Report 85480, $331 \mathrm{p}$.

Oberg, K.A., and others, 2005, Quality-assurance plan for discharge measurements using acoustic Doppler current profilers: U.S. Geological Survey Scientific Investigations Report 2005-5183, 35 p.

Rantz, S.E., and others, 1982, Measurements and computation of streamflow, volumes 1 and 2: U.S. Geological Survey Water-Supply Paper 2175, 631 p.

Sauer, V.B., 2002, Standards for the analysis and processing of surface-water data and information using electronic methods: U.S. Geological Survey Water-Resources Investigations Report 01-4044, $91 \mathrm{p}$.

Sauer, V.B., and Meyer, R.W., 1992, Determination of errors in individual discharge measurements: U.S. Geological Survey Open-File Report 92-144, 21 p. 
Sauer, V.B., and Turnipseed, D.P., 2010, Stage measurement at gaging stations: U.S. Geological Survey Techniques and Methods, book 3, chap. A7, 45 p. [Also available at http://pubs.usgs.gov/tm/tm3-a7/.] Shearman, J.O., 1990, User's manual for WSPRO - A computer model for water surface profile computations: U.S. Federal Highway Administration Report FHWA-IP-89-027, 187 p.

Smoot, G.F., and Novak, C.E., 1968, Calibration and maintenance of vertical-axis type current meters: U.S. Geological Survey Techniques of Water-Resources Investigations, book 8, chap. B2, 15 p.

Turnipseed, D.P., and Sauer, V.B., 2010, Discharge measurements at gaging stations: U.S. Geological Survey Techniques and Methods, book 3, chap. A8, 87p. [Also available at http://pubs.usgs.gov/tm/tm3-a8/.]

U.S. Army Corps of Engineers, 2008, HEC-RAS River Analysis System: U.S. Army Corps of Engineers database, accessed January 2016, at www.hec.usace.army.mil.

U.S. Geological Survey, 2013, Release of CAPGUI version 1.0 and SACGUI version 1.0: U.S. Geological Survey OSW Informational and Technical Note 2013.32.

Wagner, R.J., Kimbrough, R.A., and Turney, G.L., 2007, Quality-assurance plan for water-quality activities in the U.S. Geological Survey Washington Water Science Center: U.S. Geological Survey Open-File Report 2007-1307, 48 p. 
This page left intentionally blank 


\section{Appendix A. Office of Surface Water, Quality of Water Branch, Water Resources Division Memorandums, and Informational and Technical Notes Cited}

The following memorandums and notes were cited in the report:

Office of Surface Water Technical Memorandum 2014.06 (not available online at time of publication of this report)

Office of Surface Water Technical Memorandum 2014.04

Office of Surface Water Technical Memorandum 2014.03

Office of Surface Water Technical Memorandum 2014.02

Office of Surface Water Technical Memorandum 2013.04

Office of Surface Water Technical Memorandum 2013.02

Office of Surface Water Technical Memorandum 2012.04

Office of Surface Water Technical Memorandum 2012.01

Office of Surface Water Technical Memorandum 2011.08

Office of Surface Water Technical Memorandum 2010.07

Office of Surface Water Technical Memorandum 2010.06

Office of Surface Water Technical Memorandum 2010.03

Office of Surface Water Technical Memorandum 2010.02

Office of Surface Water Technical Memorandum 2009.05

Office of Surface Water Technical Memorandum 2009.04

Office of Surface Water Technical Memorandum 2007.01

Office of Surface Water Technical Memorandum 2006.01

Office of Surface Water Technical Memorandum 2005.08

Office of Surface Water Technical Memorandum 2004.04

Office of Surface Water Technical Memorandum 99.07

Office of Surface Water Technical Memorandum 99.06

Office of Surface Water Technical Memorandum 97.02

Office of Surface Water Technical Memorandum 96.05

Office of Surface Water Technical Memorandum 96.02

Office of Surface Water Technical Memorandum 96.01

Office of Surface Water Technical Memorandum 95.03

Office of Surface Water Technical Memorandum 93.07

Office of Surface Water Technical Memorandum 93.01

Office of Surface Water Technical Memorandum 92.11

Office of Surface Water Technical Memorandum 92.10

Office of Surface Water Technical Memorandum 92.09

Office of Surface Water Technical Memorandum 92.04

Office of Surface Water Technical Memorandum 91.15

Office of Surface Water Technical Memorandum 90.08

Office of Surface Water Technical Memorandum 90.01

Office of Surface Water Technical Memorandum 89.08

Office of Surface Water Technical Memorandum 89.07

Office of Surface Water Technical Memorandum 88.18

Office of Surface Water Technical Memorandum 88.07

Office of Surface Water Technical Memorandum 87.05 
Office of Surface Water Technical Memorandum 85.17

Quality of Water Branch Technical Memorandum 80.17

Quality of Water Branch Technical Memorandum 80.07

Quality of Water Branch Technical Memorandum 77.07

Quality of Water Branch Technical Memorandum 76.17

Quality of Water Branch Technical Memorandum 76.04

Surface Water Branch Technical Memorandum 84.05

Surface Water Branch Technical Memorandum 85.07

Surface Water Branch Technical Memorandum 84.05

Water Resources Division Memorandum 99.34

Water Resources Division Memorandum 92.59

WRD Policy Memorandum no. 2010.02

OSW Informational and Technical Note 2013.32 


\section{Appendix B. Washington Water Science Center Note Sheets for Recording Surface-Water Data}

1. Streamgaging cableways -Western Region Inspection Checklist

2. Form P-19, Gaging Station Service Notes

3. Peg Test and Gaging Station Levels Notes form

4. Form 9-275F, Discharge Measurement Notes

5. Form 9-275D, Miscellaneous Field Notes

6. Form T-9335, Crest-Stage Gage Notes

7. Form T-9334, Snow Survey Notes

8. Form 9-275-I, ADCP Discharge Measurement Notes (available at http://hydroacoustics.usgs.gov/movingboat/forms/ADCPQmForm-20081024-2up.pdf).

9. ADVM Installation and Initial Setup (available at http://hydroacoustics.usgs.gov/indexvelocity/quicksheets/IndexVelocityInstallationForm.pdf).

10. Index-Velocity Gage Inspection Form (available at http://hydroacoustics.usgs.gov/indexvelocity/quicksheets/IndexVelocityInspectionForm-v6.pdf). 

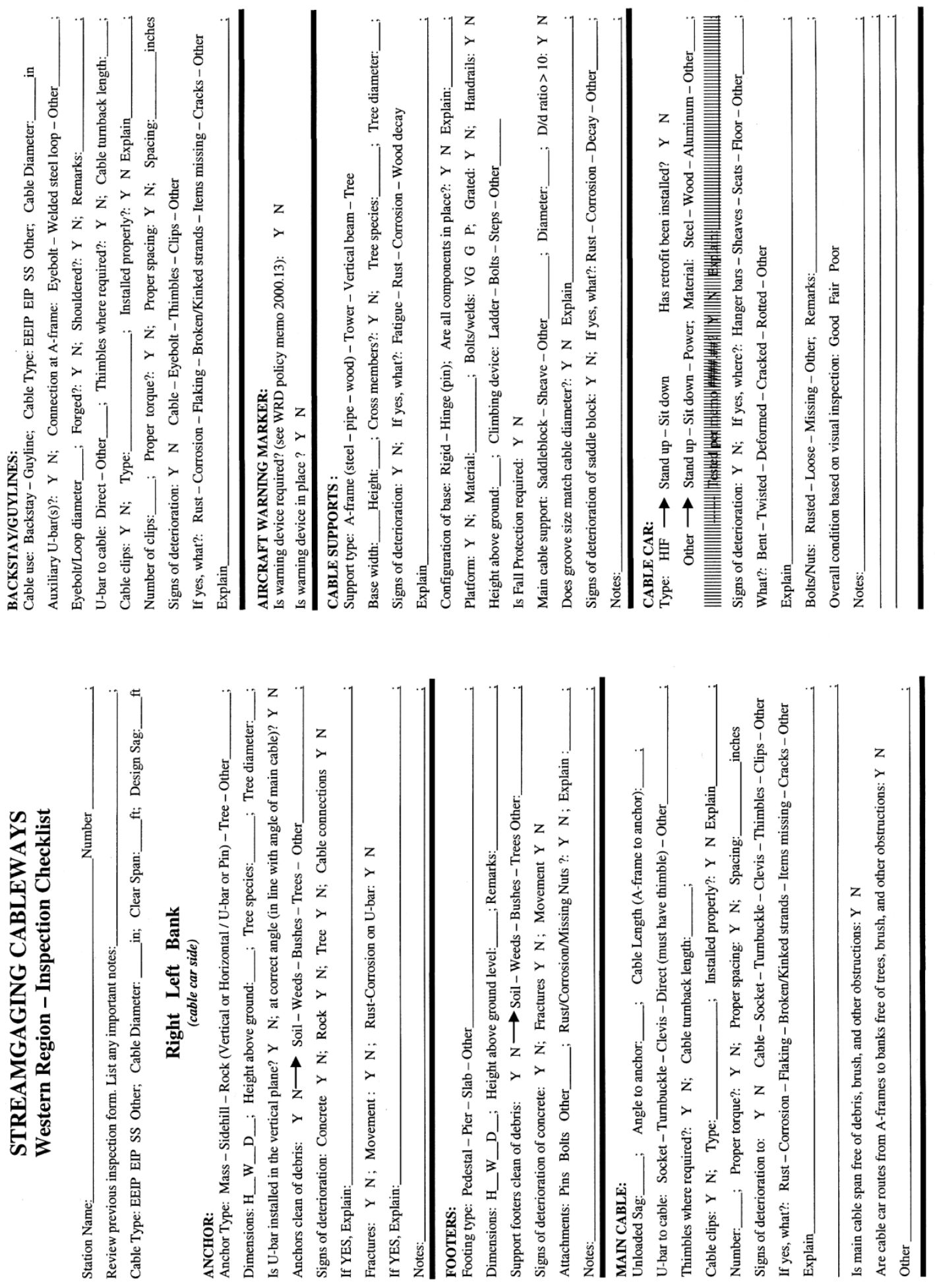

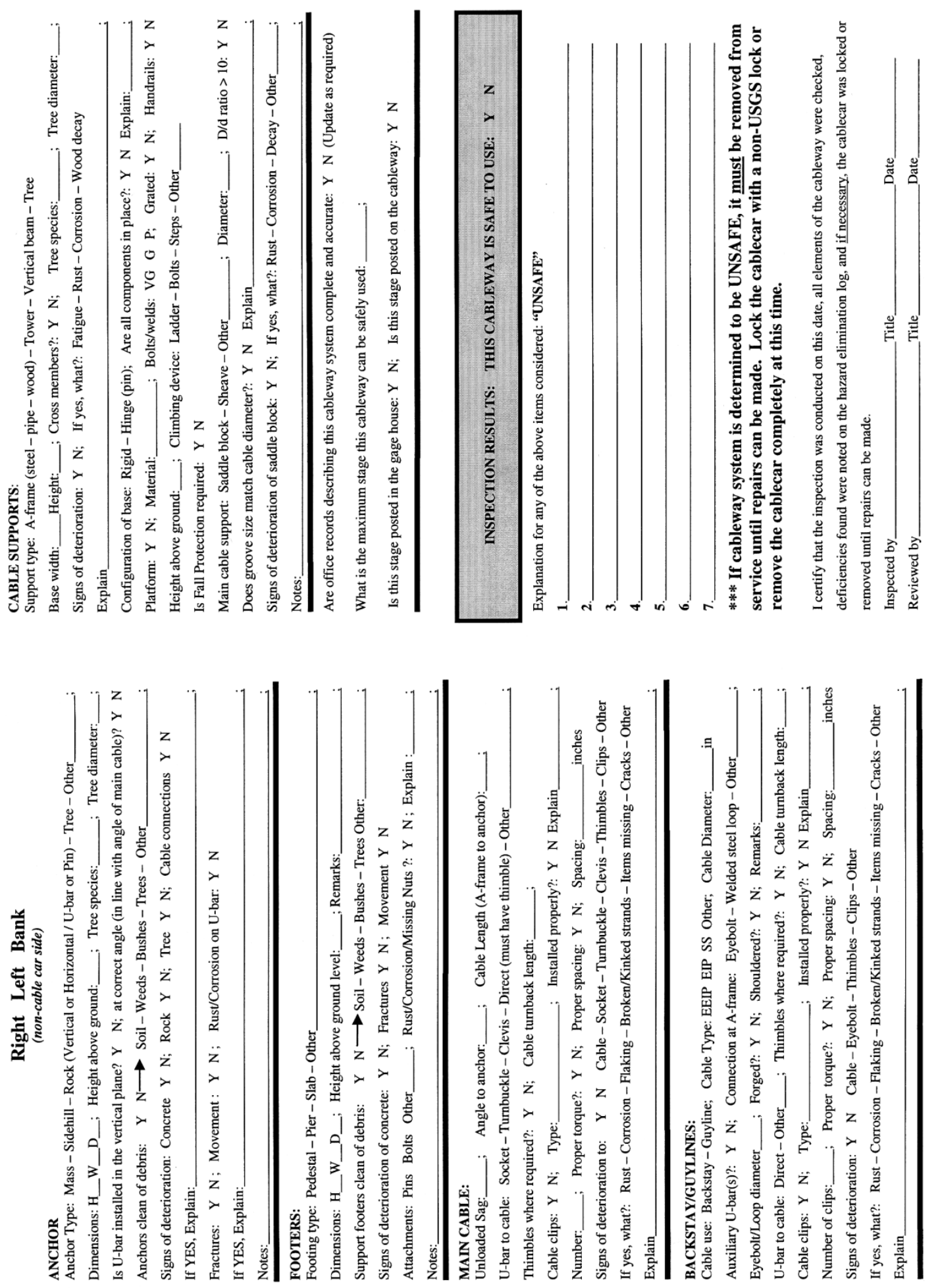
Appendix B2. Form P-19, Gaging Station Service Notes

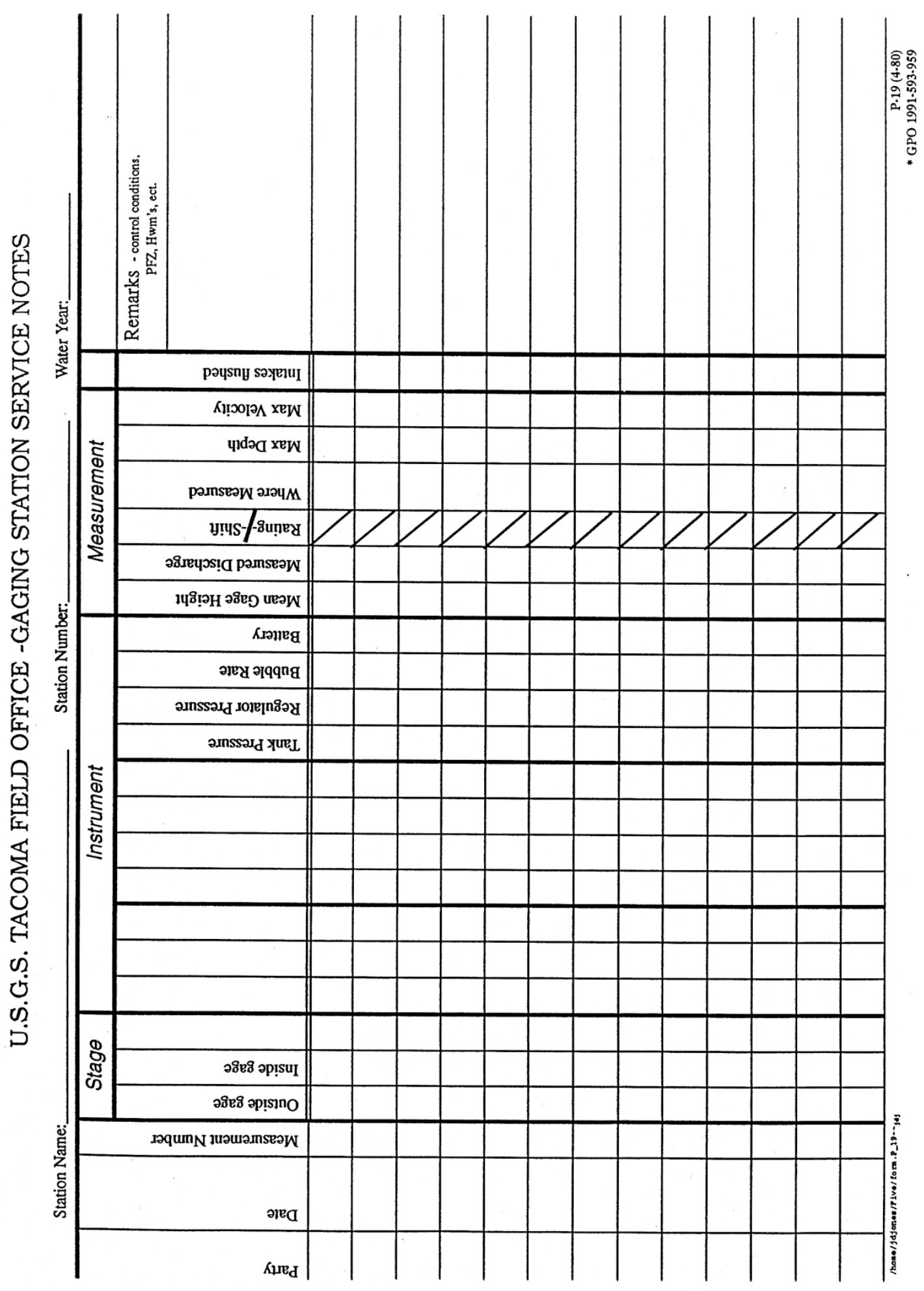


Appendix B3. Peg Test and Gaging Station Levels Notes form

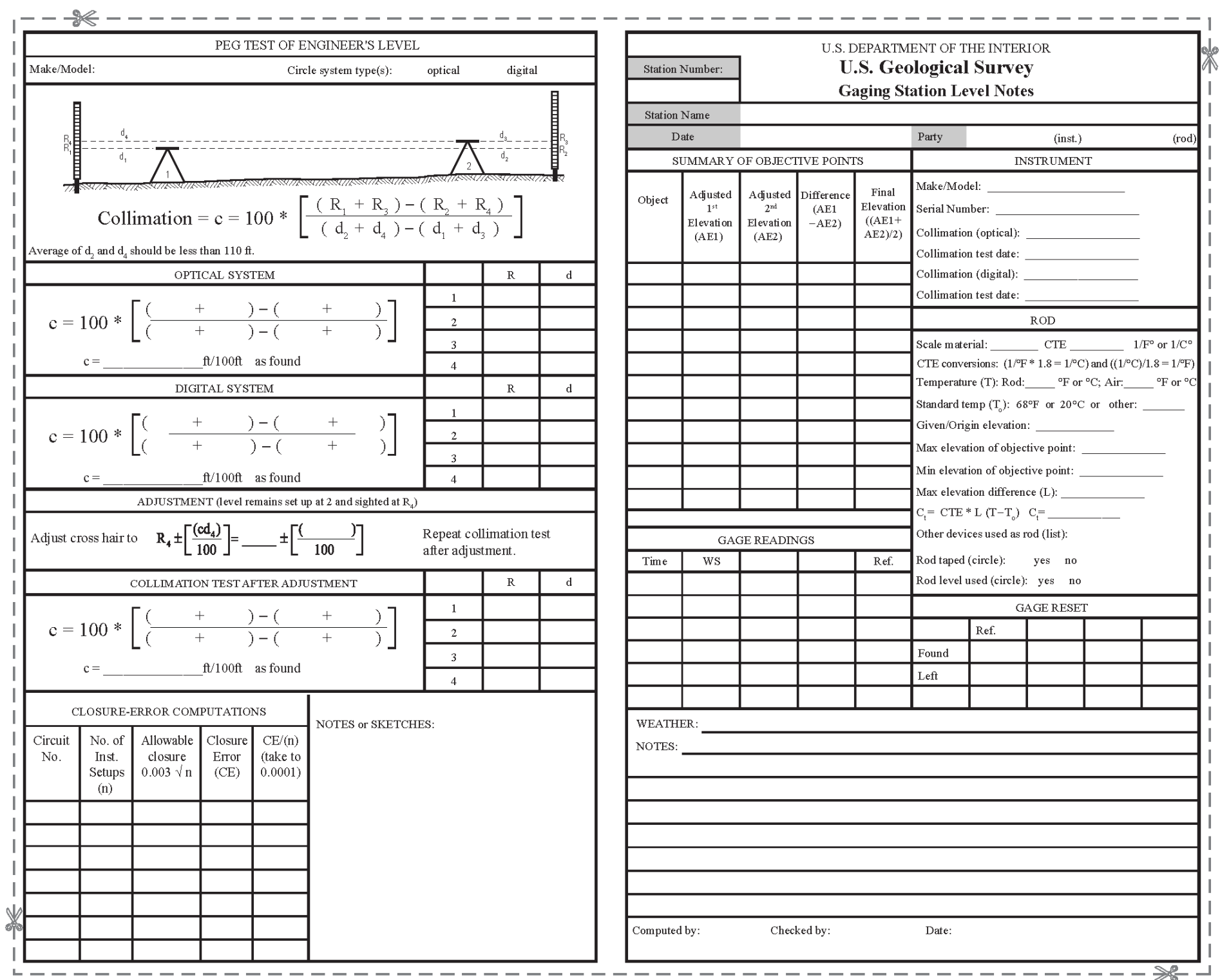


Appendix B3. Peg Test and Gaging Station Levels Notes form-Continued

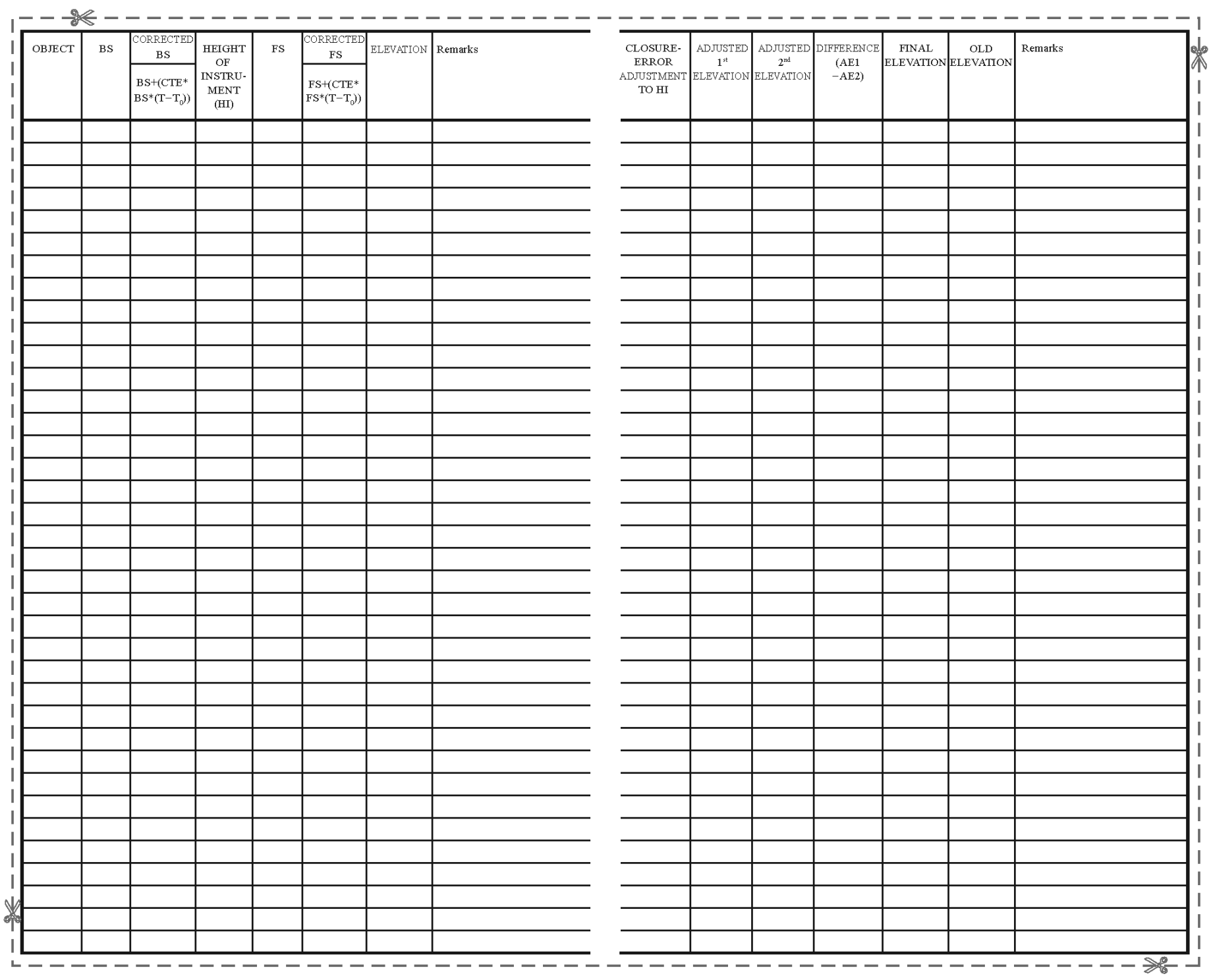


Appendix B4. Form 9-275 F, Discharge Measurement Notes
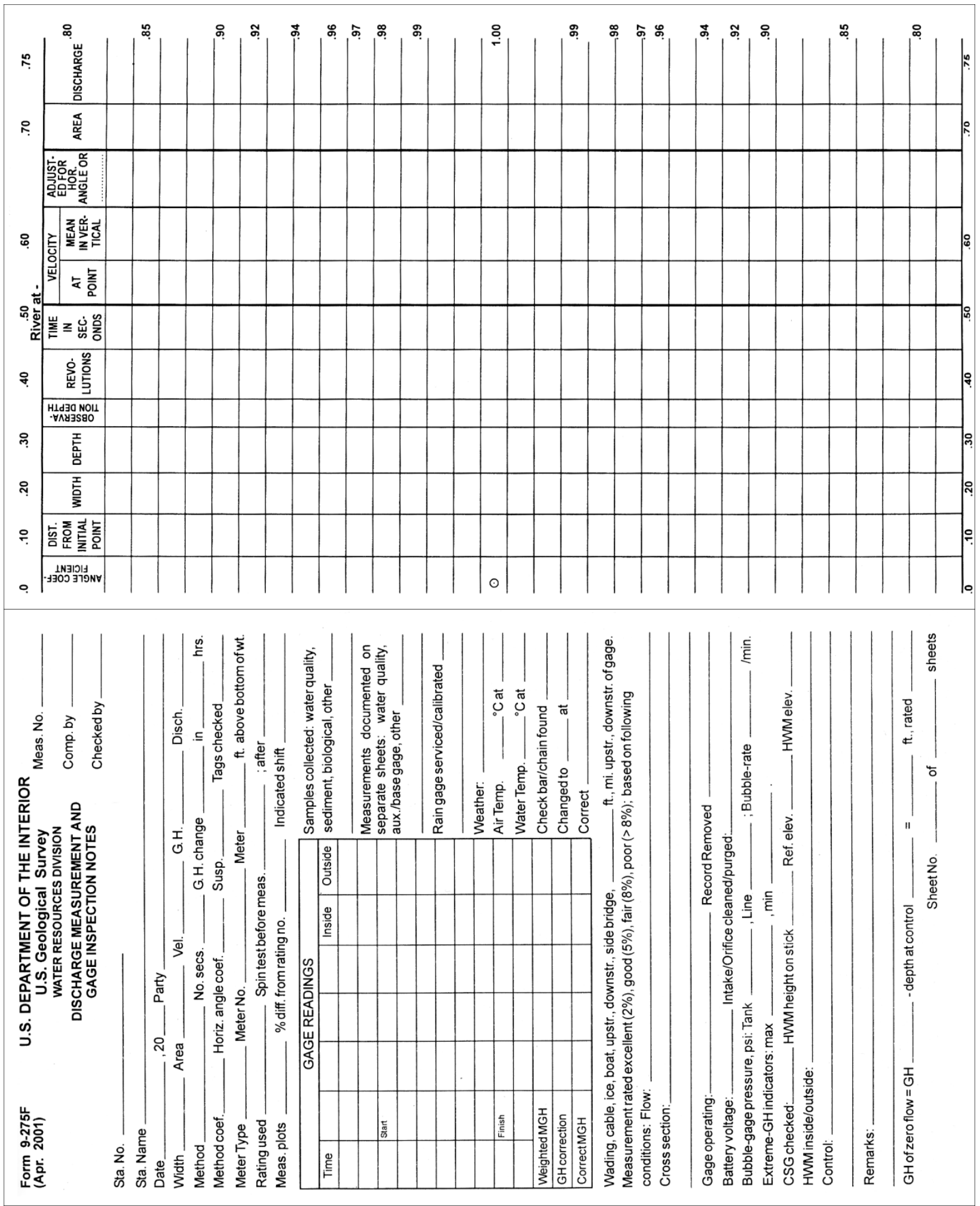
Appendix B4. Form 9-275 F, Discharge Measurement Notes-Continued

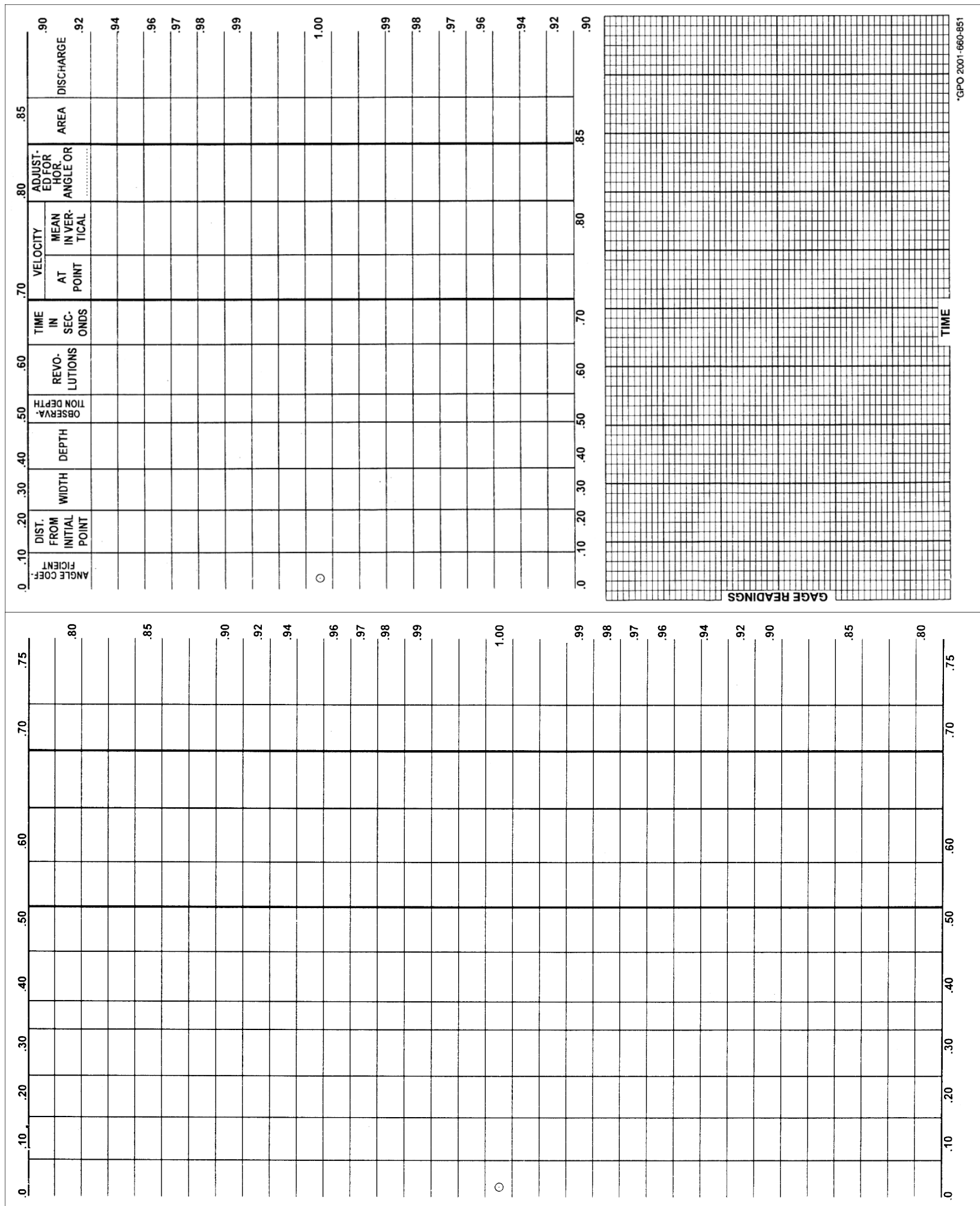


Appendix B5. Form 9-275D, Miscellaneous Field Notes

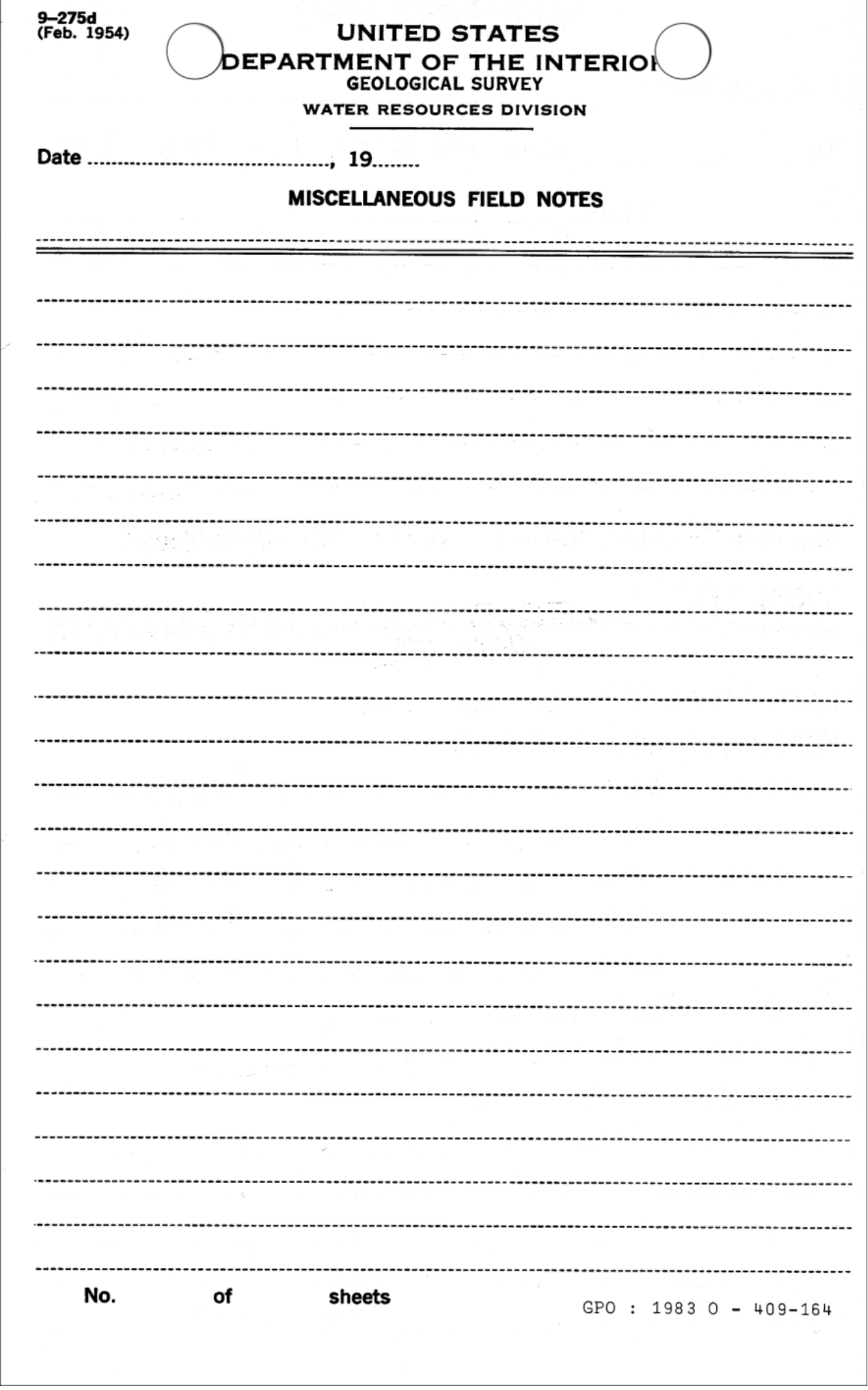




\section{Appendix B6. Form T-9335, Crest-Stage Gage Notes}

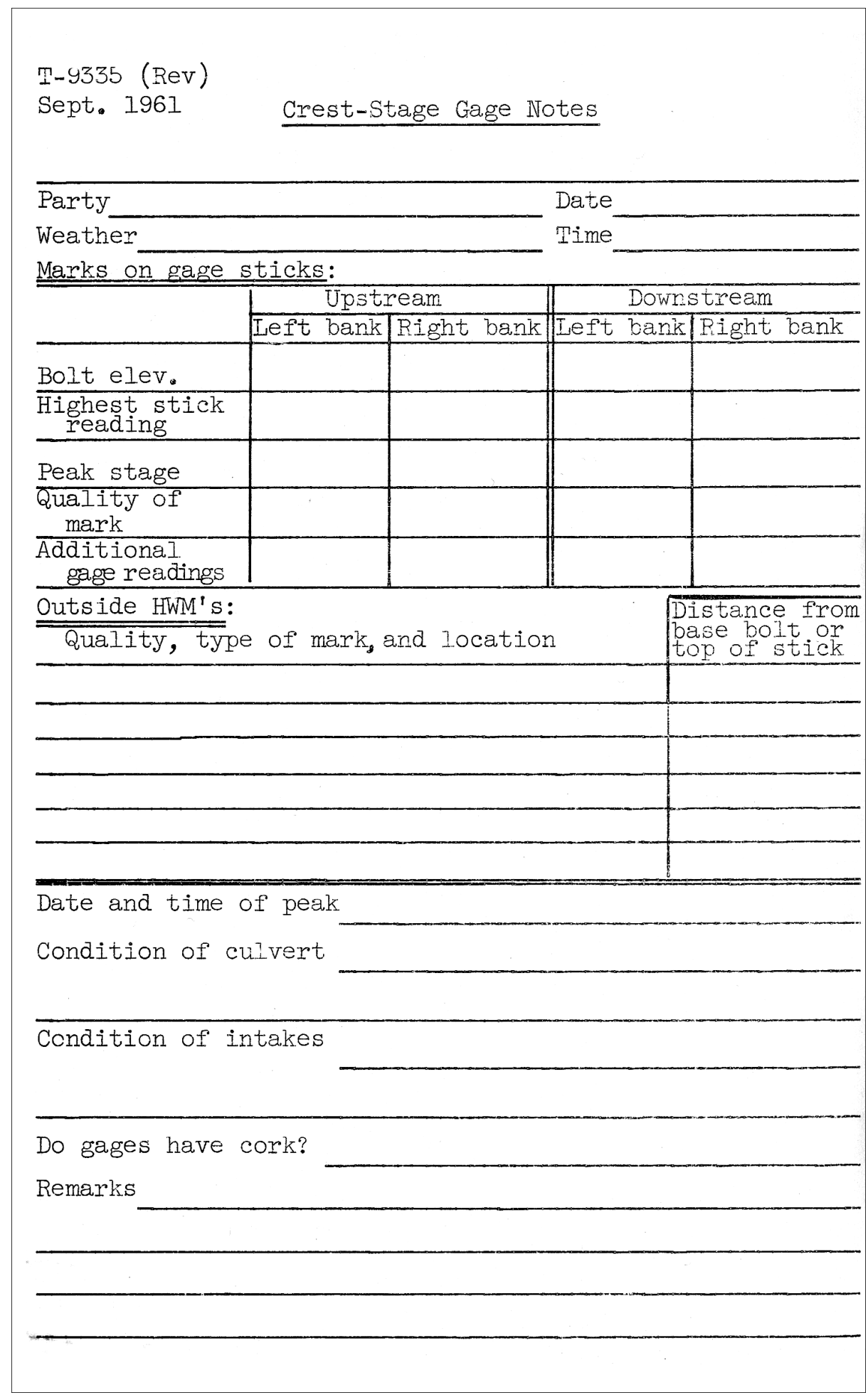


Appendix B7. Form T-9334, Snow Survey Notes
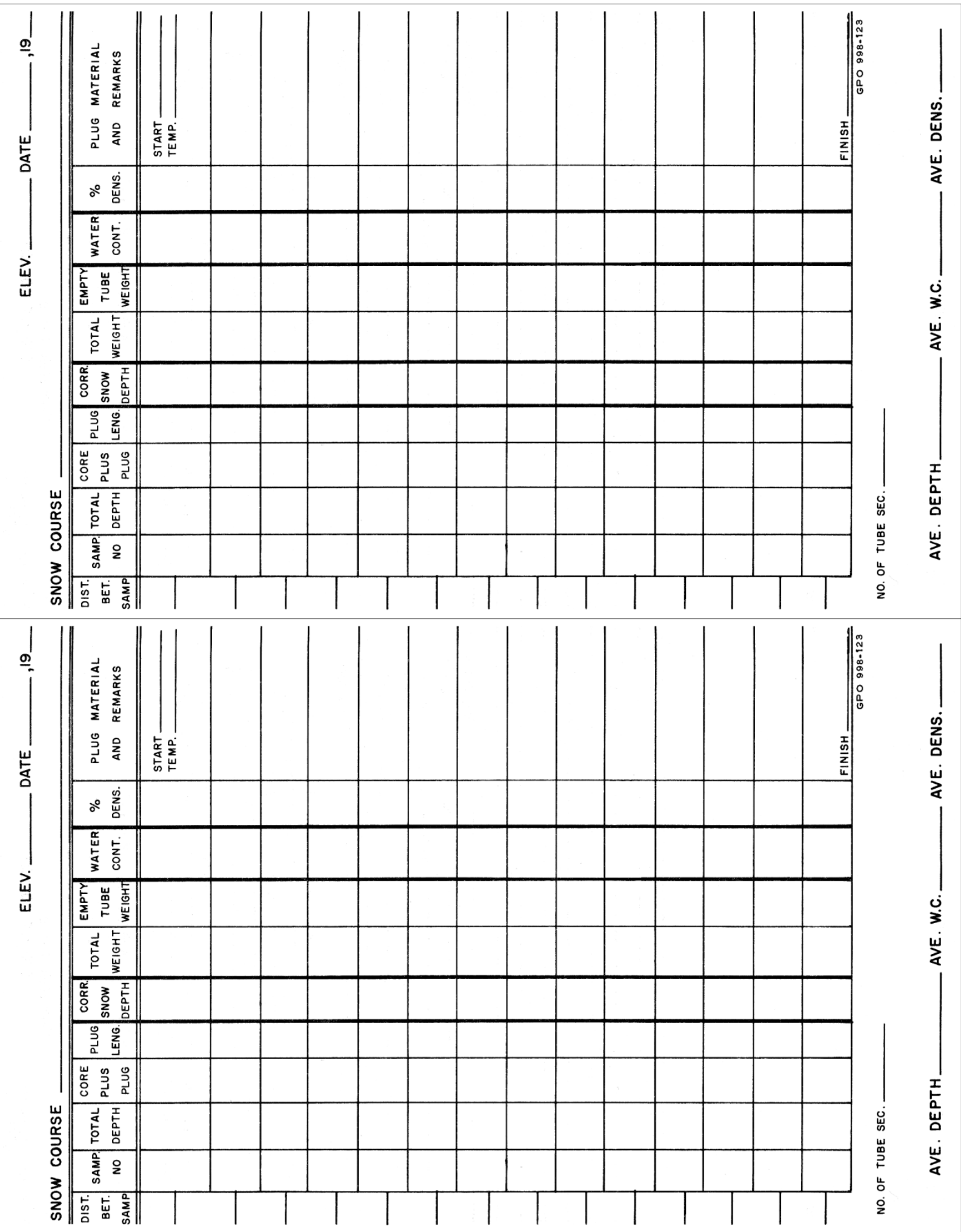
Appendix B8. Form 9-275-I, ADCP Discharge Measurement Notes
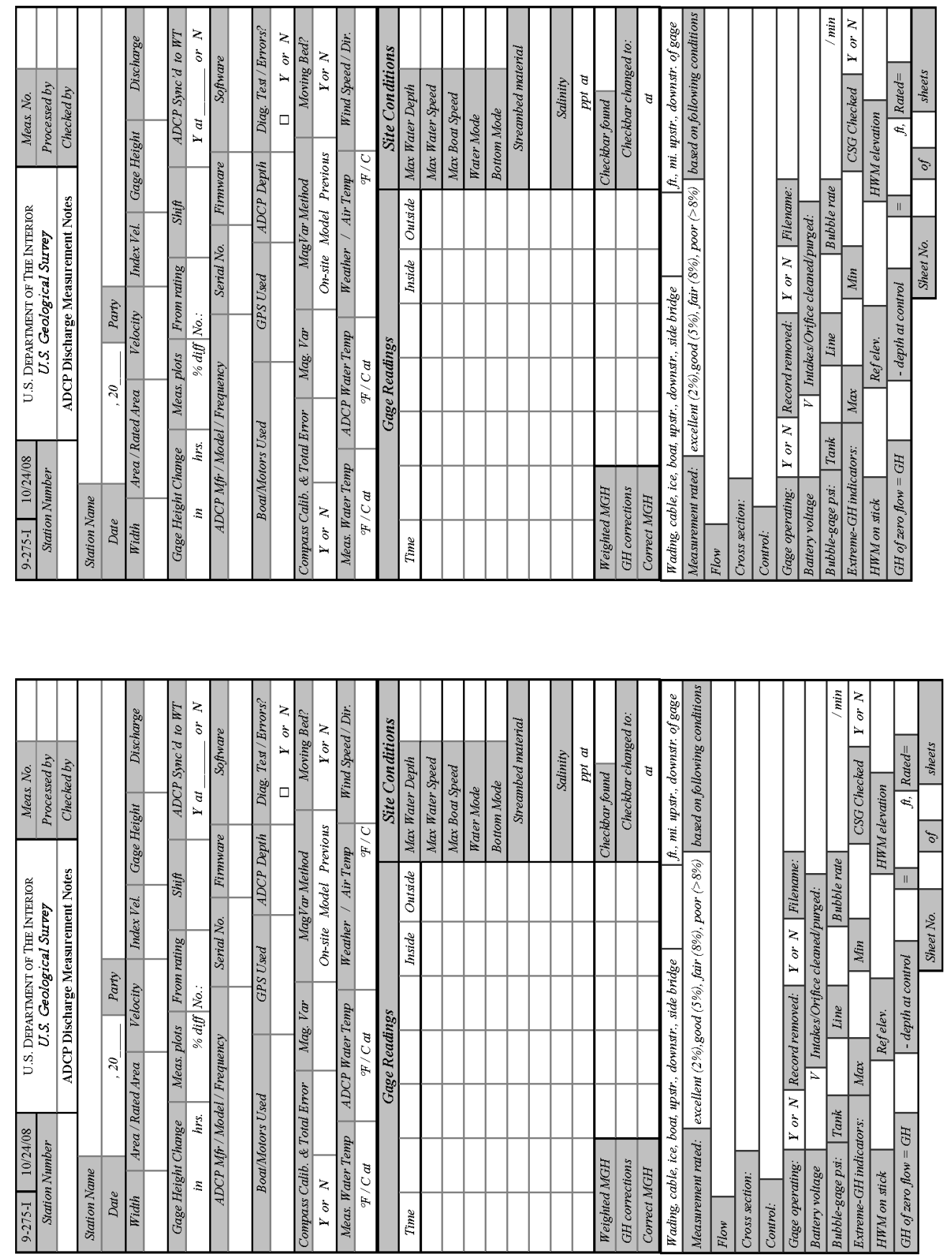


\section{Appendix B8. Form 9-275-I, ADCP Discharge Measurement Notes-Continued}

\begin{tabular}{|c|c|c|c|c|c|c|c|c|c|}
\hline \multicolumn{7}{|c|}{ Acoustic Profiler Discharge Measurement Notes } & \multicolumn{3}{|c|}{ Filename Prefix: } \\
\hline Left Bank: & \multicolumn{5}{|c|}{ Sloping Vertical Other: } & \multirow{3}{*}{$\begin{array}{c}\text { Right Bank: } \\
\begin{array}{c}\text { Total } \\
\text { Discharge }\end{array}\end{array}$} & Sloping & Vertical & Other: \\
\hline \multirow{2}{*}{ Transect No. } & \multicolumn{3}{|c|}{ Starting } & \multicolumn{2}{|c|}{ Ending } & & & & \multirow{2}{*}{ Notes } \\
\hline & Bank & Time & Distance & Distance & Time & & & & \\
\hline & $\mathrm{L} R$ & & & & & & & & \\
\hline & $\mathrm{L} \quad \mathrm{R}$ & & & & & & & & \\
\hline & $L \quad R$ & & & & & & & & \\
\hline & L R & & & & & & & & \\
\hline & $\mathrm{L} \quad \mathrm{R}$ & & & & & & & & \\
\hline & $\mathrm{L} R$ & & & & & & & & \\
\hline & $L \quad R$ & & & & & & & & \\
\hline & $L \quad R$ & & & & & & & & \\
\hline & $L R$ & & & & & & & & \\
\hline & $L R$ & & & & & & & & \\
\hline & $\mathrm{L} R$ & & & & & & & & \\
\hline & $L \quad R$ & & & & & & & & \\
\hline & L R & & & & & & & & \\
\hline Notes & & & & & & & & & \\
\hline
\end{tabular}

\begin{tabular}{|c|c|c|c|c|c|c|c|c|c|}
\hline \multicolumn{7}{|c|}{ Acoustic Profiler Discharge Measurement Notes } & \multicolumn{3}{|c|}{ Filename Prefix: } \\
\hline Left Bank: & \multicolumn{3}{|c|}{ Sloping Vertical Other: } & & & \multirow{3}{*}{$\begin{array}{c}\text { Right Bank: } \\
\begin{array}{c}\text { Total } \\
\text { Discharge }\end{array}\end{array}$} & Sloping & Vertical & Other: \\
\hline \multirow{2}{*}{ Transect No. } & \multicolumn{3}{|c|}{ Starting } & \multicolumn{2}{|c|}{ Ending } & & & & \multirow{2}{*}{ Notes } \\
\hline & Bank & Time & Distance & Distance & Time & & & & \\
\hline & $L \quad R$ & & & & & & & & \\
\hline & $L \quad R$ & & & & & & & & \\
\hline & $L \quad R$ & & & & & & & & \\
\hline & $L \quad R$ & & & & & & & & \\
\hline & $\mathrm{L} \quad \mathrm{R}$ & & & & & & & & \\
\hline & $L \quad R$ & & & & & & & & \\
\hline & $L \quad R$ & & & & & & & & \\
\hline & $L \quad R$ & & & & & & & & \\
\hline & $\mathrm{L} \quad \mathrm{R}$ & & & & & & & & \\
\hline & $L \quad R$ & & & & & & & & \\
\hline & $L \quad R$ & & & & & & & & \\
\hline & $\mathrm{L} \quad \mathrm{R}$ & & & & & & & & \\
\hline & $L \quad R$ & & & & & & & & \\
\hline Notes & & & & & & & & & \\
\hline
\end{tabular}




\begin{tabular}{|c|c|c|c|c|c|}
\hline Station No. & \multicolumn{5}{|c|}{ Station Name } \\
\hline Date Installed & \multicolumn{5}{|c|}{ Installed by } \\
\hline Mfgr/Model & Acoustic Freq. & Firmware Ver. & Serial \# & HIF \# & USGS W \# \\
\hline \multicolumn{4}{|c|}{ ADVM Mounted on } & \multicolumn{2}{|c|}{ Cable Length } \\
\hline \multicolumn{4}{|c|}{ LB / RB / Other (describe): } & \multicolumn{2}{|r|}{$\mathrm{ft} / \mathrm{m}$} \\
\hline \multicolumn{2}{|c|}{ Initial Beam Check Filename } & \multicolumn{4}{|c|}{ Boundary Reflection Identified? } \\
\hline & & & & & at $\mathrm{ft} / \mathrm{m}$ \\
\hline \multirow[t]{2}{*}{ Water Temp } & ADVM Temp & Salinity & ADVM Sal. & Deploy Sensor & SDI-12 Address \\
\hline & & & & SDI-12 or Auto. & \\
\hline \multirow[t]{2}{*}{ ADVM Date } & ADVM Time & \multicolumn{2}{|c|}{ Deployment Name } & \multicolumn{2}{|c|}{ Orientation correction } \\
\hline & Set @: & & & \multicolumn{2}{|c|}{ Yes or No } \\
\hline Heading & Pitch & Roll & MagVar & Depth & Press. Depth \\
\hline
\end{tabular}

\section{Mid-transducer Face Depth}

\begin{tabular}{|c|c|c|c|c|}
\hline Stage & minus & Depth to Transducers & equals & Transducer stage \\
\hline & - & & $=$ & $\mathrm{ft}$ or $\mathrm{m}$ \\
\hline
\end{tabular}

\section{SonTek ADVM Configuration}

Note: White Molex connector (jumper) connected for RS-232 communications and unplugged for SDI-12 communications \begin{tabular}{|l|l|l|l|l}
\hline Output Format & Recorder & Averaging Int. (AI) & Sampling Int. (SI) & PowerPing
\end{tabular}

\begin{tabular}{|c|c|c|c|c|c|}
\hline üput roritat & necoruer & Averagmg im. (AM) & Samping i & III. (DI) & rowerting \\
\hline & & sec. & & sec. & Off \\
\hline Cell Begin (CB) & Cell End (CE) & Blank (BD) & Cell Size (CS) & \# of Cells & \\
\hline
\end{tabular}

\begin{tabular}{|c|c|c|c|c|c|c|}
\hline $\begin{array}{l}\text { Blanking } \\
\text { Distance }\end{array}$ & $\begin{array}{l}\text { No. of Cells } \\
\text { (WN) }\end{array}$ & $\begin{array}{l}\text { Cell Size } \\
\text { (WS) }\end{array}$ & $\begin{array}{l}\text { Water Pings } \\
\text { (WP) }\end{array}$ & $\begin{array}{c}\text { Measurement } \\
\text { Interval }\end{array}$ & $\begin{array}{c}\text { Time between } \\
\text { pings (TP) }\end{array}$ & $\begin{array}{c}\text { Cells Used for } \\
\text { Index }\end{array}$ \\
\hline & & & & sec. & & \\
\hline \multicolumn{2}{|c|}{ Other Commands/Info } & & & & & \\
\hline
\end{tabular}

Comments: 
Appendix B9. ADVM Installation and Initial Setup-Continued

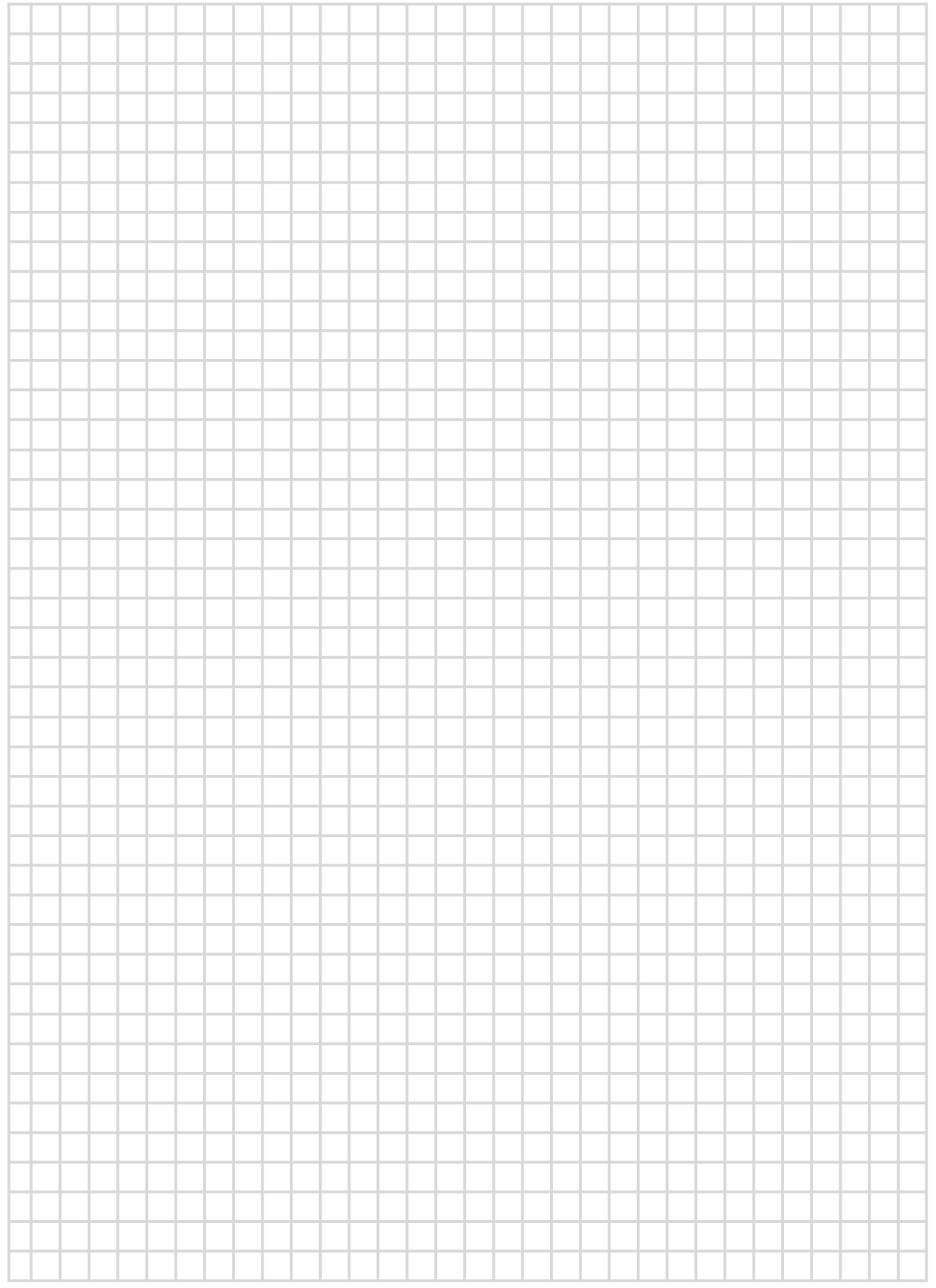




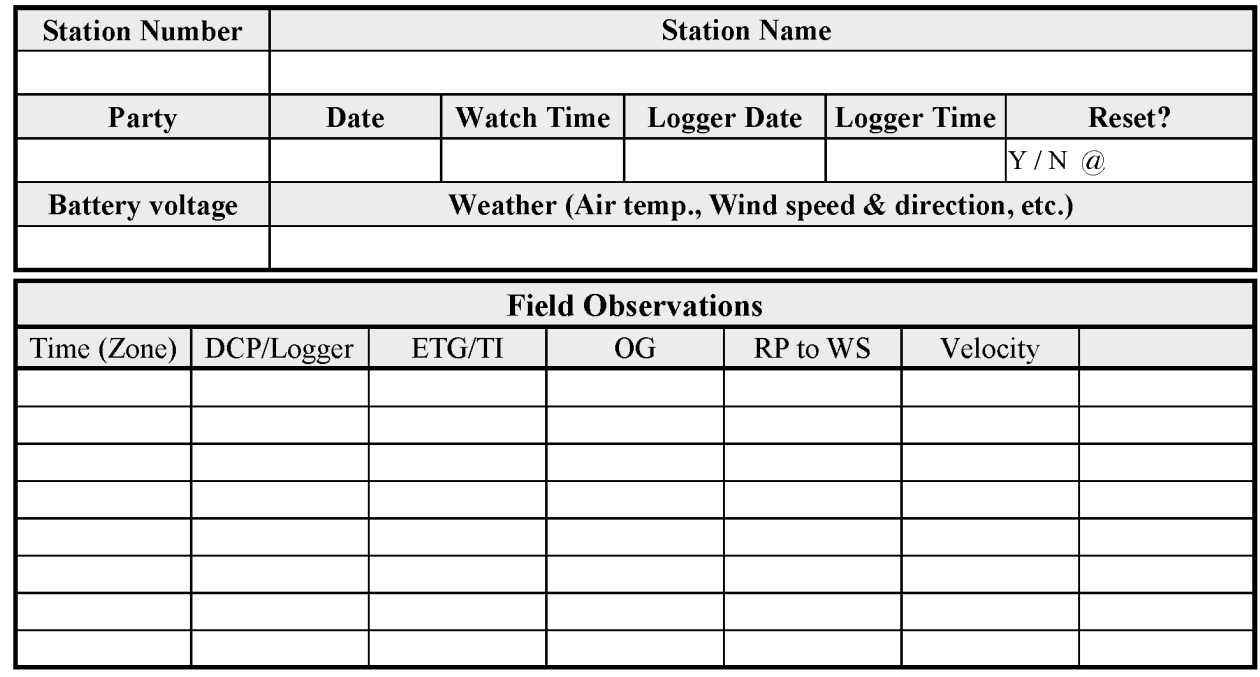

ADVM Recorder Data

\begin{tabular}{|c|c|}
\hline \multicolumn{2}{|c|}{ ADVM Recorder Data } \\
\hline Retrieve Data & Names of downloaded file(s) \\
\hline Yes or No & \\
\hline \multicolumn{2}{|c|}{ Beam Check } \\
\hline Beam Check Acceptable? & Beam Check Filename(s) \\
\hline \multicolumn{2}{|l|}{ OK or Not OK } \\
\hline $\begin{array}{l}\text { Describe Results/ } \\
\text { Corrective Measures }\end{array}$ & \\
\hline
\end{tabular}

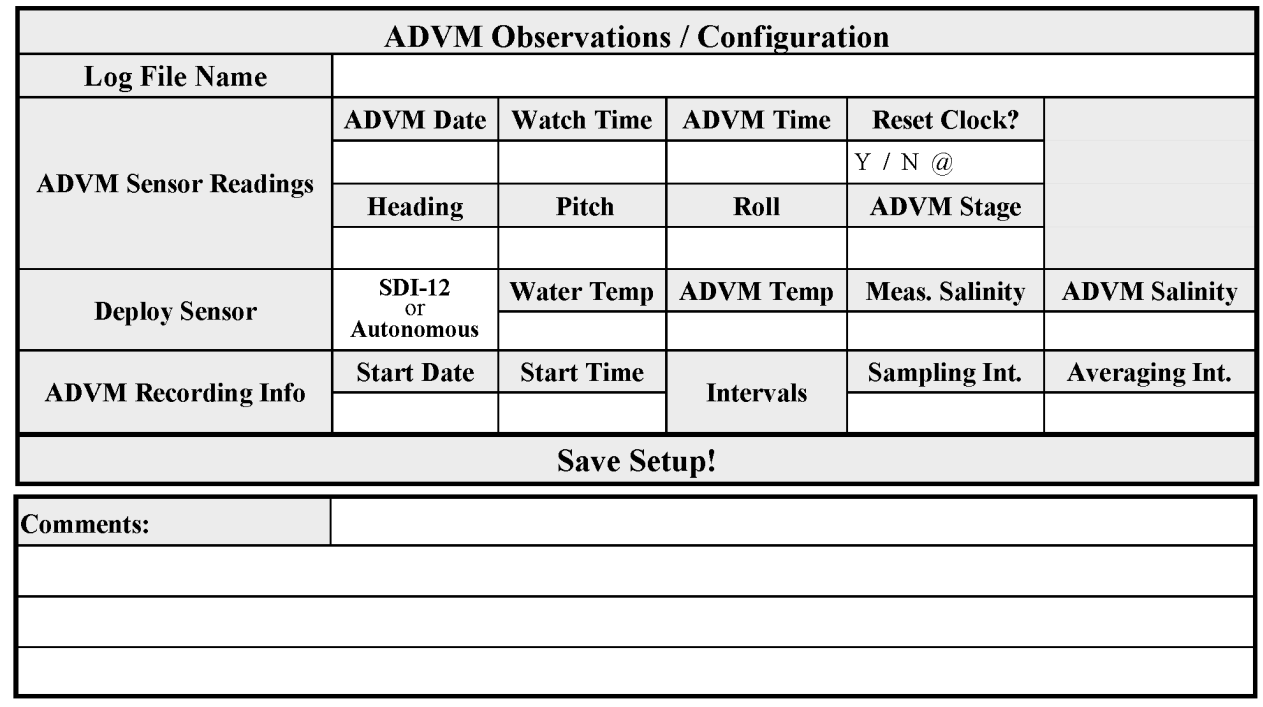




\section{Appendix C. Surface Water Gage Data Electronic File Locations}

Station Descriptions

Manuscripts

Analysis

swreview files
SIMS

hard copy, with electronic file in SIMS

RMS

SIMS link or Iligswwtwwus-nwislswrl[field_office]

All other electronic files are stored under

IData $^{1}$ specifically:

Level peg tests IDatal[field_office]ldocuments|Peg tests and with level notes stored under the stationslstation\#ILevels directory

JHAs

Most others, by station

IDatal[field_office]jiha

Each station directory contains the following subdirectories:

/EDL_Data

/Land_Use_agreements

/Levels

/Measurements

/Photos

/Record_Review

${ }^{1}$ Data are in a DFS shared directory. The root directory is different for each field office:

Iligswwqwwgs01\Data for the NW Washington Field Office, \ligswwpwwgs02\Data for the

Upper Columbia Field Office, \ligswwhwwgs02\Data for the Mid-Columbia Field Office, and IIgs $\backslash$ tacomawa-w $\backslash$ Data for the Western Washington Field Office 
Field Office subdirectories:

\begin{tabular}{|c|c|c|c|c|}
\hline Field Office & location & $\begin{array}{c}\text { RMS } \\
\text { abbreviation }\end{array}$ & $\begin{array}{c}\text { Iswr subdirectory } \\
\text { name }\end{array}$ & $\begin{array}{c}\text { Data subdirectory } \\
\text { name }\end{array}$ \\
\hline $\begin{array}{l}\text { Mid- } \\
\text { Columbia } \\
\text { Field Office }\end{array}$ & Kennewick & Mco & mid_columbia & mid_columbia \\
\hline $\begin{array}{l}\text { NW } \\
\text { Washington } \\
\text { Field Office }\end{array}$ & Ferndale & Nwd & nw_washington & nw_washington \\
\hline $\begin{array}{l}\text { Upper } \\
\text { Columbia } \\
\text { Field Office }\end{array}$ & Spokane & Uco & upper_columbia & upper_columbia \\
\hline $\begin{array}{l}\text { Western } \\
\text { Washington } \\
\text { Field Office }\end{array}$ & Tacoma & Wwo & western_washington & western_washington \\
\hline \multirow{5}{*}{ Other } & Vancouver & CVO & CVO & \\
\hline & Projects & p53 & - & Projects $^{1}$ \\
\hline & Idaho & - & - & idaho \\
\hline & Oregon & - & - & oregon \\
\hline & $\begin{array}{c}\text { British } \\
\text { Columbia } \\
\end{array}$ & - & - & - \\
\hline
\end{tabular}

\footnotetext{
${ }^{1}$ The $\backslash$ Data $\backslash$ projects subdirectory is provided for data collected at non-field-office-run stations, usually data collected only for a limited time.
}

The Data directory structure is diagramed on the next page. 


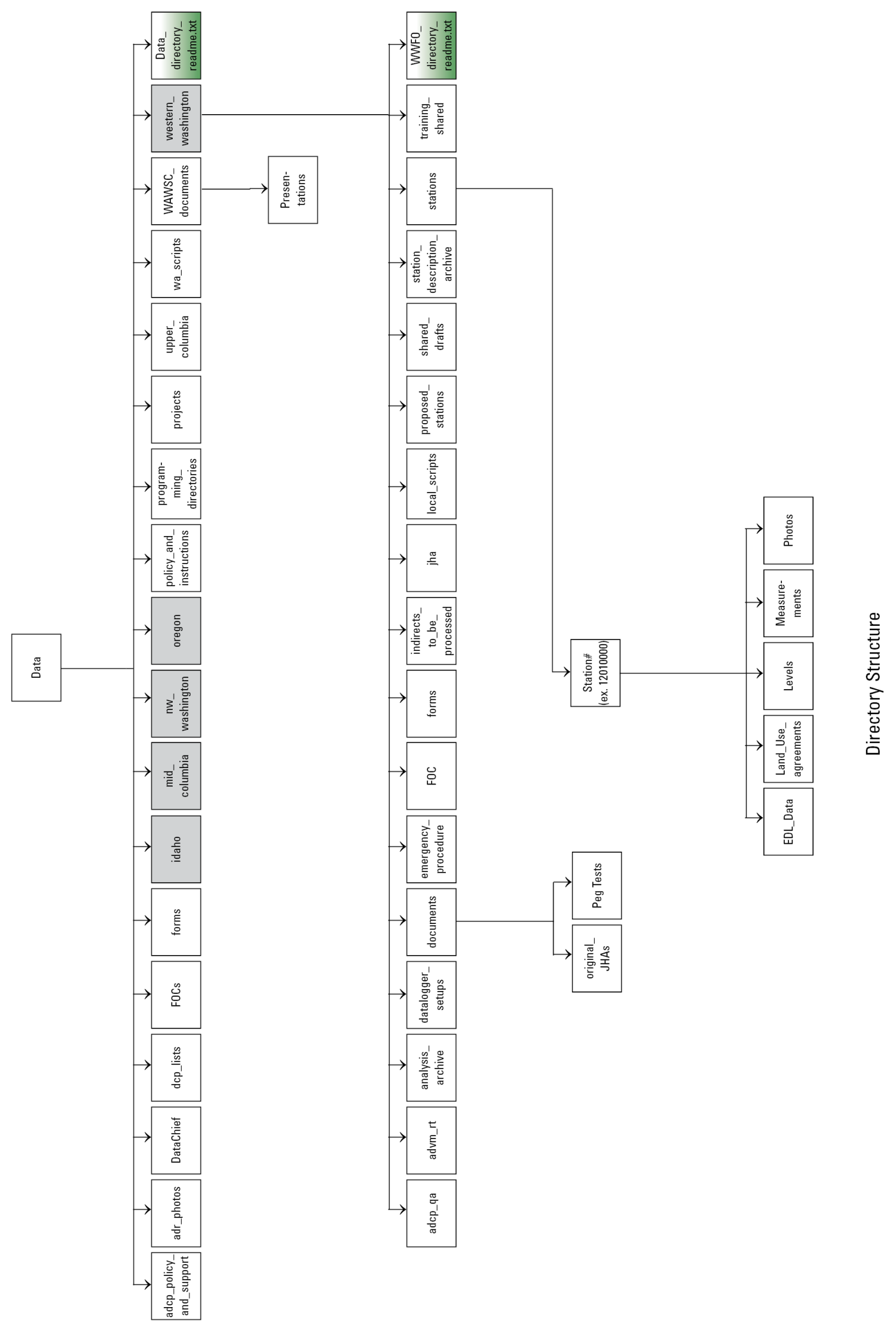


This page left intentionally blank 


\section{Appendix D. Acoustic Doppler Current Profiler (ADCP) Wading Limitations and Precautions.}

\section{Background:}

The Office of Surface Water (OSW) has made a recommendation discouraging the practice of wading ADCP measurements because of poor practices in the field. However, OSW has not banned wading ADCP measurements, recognizing that they can be done well. The purpose of this document is to provide the WAWSC field hydrographer with guidance, should a wading ADCP measurement be selected as the most appropriate method at a particular site and time.

\section{Recommendations:}

Wading ADCP measurements will be considered sound as long as the following conditions are met:

1. The hydrographer has attended or watched a brief training session on the potential limitations of, and precautions to be taken for, wading ADCP measurements.

2. Each wading ADCP measurement is fully documented in the field form, and explains why the method was selected as the best option for that particular site and time. Unless already documented in the Station Description, the field form also should note the setup and procedure used, including the boat maneuvering method at the edges.

3. Sites at which wading ADCP measurements are made with some regularity should:

a. Make a check measurement with a FlowTracker ${ }^{\mathbb{R}}$ from time to time, if the velocity profile is standard; and

b. Explain in the Station Description under which circumstances wading $\mathrm{ADCP}$ measurements may be appropriate as the solution of last resort, as well as specifics on how the wading ADCP measurement should be conducted (tagline, hydrographer distance from ADCP, boat handling at the edge, etc.).

4. Initially, through January 2016, the hydrographer notifies the Hydroacoustic Specialist any time a wading ADCP measurement has been made (include station, date, and reason for wading ADCP measurement). 


\section{Limitations:}

As with any measurement method, there are potential pitfalls if hydrographers are not conscientious in their work. Mindfulness and good procedures will avoid most of the following pitfalls:

- Potential sporadic movement of the boat, especially if not using a tagline and tether.

- Potential interference with the acoustic beams, if the hydrographer is too close to the boat.

- Potential measured-flow interference

o if wading upstream (which usually is not done),

o if too close to the boat, and

o especially a concern in low velocities (you may continue to disrupt the water, unlike with a mid-section measurement where your movement temporarily stops).

\section{Precautions:}

The following precautions must be taken when making a wading ADCP measurement:

- A tagline is set up, the ADCP is tethered to the tagline with a carabiner, and a 7 - to $10-\mathrm{ft}$ (depending on conditions) pull rope is attached to the tether carabiner.

- From the downstream side of the tagline, the hydrographer uses the pull rope to smoothly guide the boat across the cross section, taking care at the edges to keep his/her distance from the boat.

- At the edges:

o Starting edge - in order to hold the ADCP at the edge while still maintaining a distance from the boat and transducer beams, the hydrographer may need to be initially farther downstream of the boat for the 10 edge pings, before moving closer to the cross section of the boat while beginning to pull it (the boat) across.

o Ending edge - in order to hold the ADCP at the edge while still maintaining a distance from the boat and transducer beams, the hydrographer may once again need to move farther downstream or, if possible, smoothly move up onto the bank to hold the boat for the final 10 pings.

- In extremely low velocities, the hydrographer must assess the potential for creating or disturbing flow in the measurement cross section. If the hydrographer cannot be in the water without disturbing the measured flow, then another measurement method should be used. 


\title{
Appendix E. Washington Water Science Center Directory Structure for Surface Water Electronic Field Data and Record Reviews
}

Electronic data collected in the field is filed by the station number associated with the data collected. All information should be entered in SiteVisit, including levels, measurements, calibration, inspections, etc. The root directory for surface-water data is located on the igswwtwigs01network in the TacomaWA-W/Data directory. The Data directory has five directories for electronic data, one for each field office and one for projects: mid_columbia, nw_washington, upper_columbia, western_washington, and projects. A "stations" sub directory under these field-office and project directories contains all the individual station directories. For example, to find the directory for station 12041200, a station operated by the Western Washington Field Office, navigate to the following pathname:

igswwtwigs01//TacomaWA-W/Data/western_washington/stations/12041200

Within each station directory, a specific directory structure is maintained with specific naming formats. The following is an outline of the directory pathnames and naming formats to be used for all field data collected for a particular station. An example will help illustrate the structure and naming formats (in red text):

\section{Directory structure example for station number 12134500 :}

\section{$/ 12134500$}
/ADVM (details below)
/EDL_Data
/Land_Use_Agreements
/Levels
/Measurements (details below)
/Photos
/Record_Review (details below)

Specifics for information under subdirectory /ADVM

\begin{abstract}
/ADVM
(In this subdirectory, include the rating-development worksheet, cross-section information, Areacomp2 output and rating. Also, include files of the 1-minute data sync from the ADVM and ADCP. The ADCP measurement is stored in the /Measurements subdirectory, as described below.)
\end{abstract}


Specifics for information under subdirectory /Measurements

Note that the following file naming conventions should be used for miscellaneous files that may need to be filed in the subdirectory for a specific measurement:

- Mean Gage Height Form (from internal Data Web page):

StationNo.Qnum_correctMGH.xlsm

/Measurements - each directory includes ALL files generated for that day, including electronic files and scanned handwritten notes.

Note: If software is used to process mechanical-meter measurements, please name the directory after the software, such as xxxx.aquacalc or xxxx.swami. If mechanical-meter measurements are not processed with software, please name the directory after the mechanical meter, such as xxxx.aa or xxxx.pygmy.

2014)

/WY2012 (note that WY directory naming format is no longer used starting with WY

/WY2013

/12134500.20140719.572.aa

(The directory-naming format is stationNo.date.measurementNo.devicename; directory contains all AA current-meter files, scanned notes, etc. If software was used to process the AA current-meter measurements, please use a directory named after the software instead; for example, 12134500.20140719.572.aquacalc or 12134500.20140719.572.swami.)

\section{/12134500.20140720.573.pygmy}

(The directory-naming format is stationNo.date.measurementNo.devicename; directory contains all Pygmy meter files, scanned notes, etc. If software was used to process the Pygmy-meter measurements, please use a directory name that is named after the software instead; for example, 12134500.20140720.573.aquacalc or

\subsubsection{3.swami.)}

\section{/12134500.20140721.574.aquacalc}

(The directory-naming format is stationNo.date.measurementNo.devicename; directory contains all AquaCalc ${ }^{\circledR}$ files, any field sheets; for example, SWAMI, scanned notes, etc. This directory is used for mechanical-meter measurements that were processed with AquaCalc ${ }^{\circledR}$ software.)

Example illustrating file-naming conventions:

12134500.577.csv

\section{/12134500.20140722.575.swami}

(The directory-naming format is stationNo.date.measurementNo.devicename; directory contains any field sheets - for example, SWAMI, scanned notes, etc. This directory is used for mechanical-meter measurements that were processed with SWAMI software.) 


\section{/12134500.20140723.576.m9}

(The directory-naming format is stationNo.date.measurementNo.devicename; directory contains all M9 files, Extrap files, etc., any field sheets-for example, SWAMI, scanned notes, etc.)

\section{/12134500.20140724.577.streampro}

(The directory-naming format is stationNo.date.measurementNo.devicename; directory contains all StreamPro files, Extrap files, etc., any field sheets-for example, SWAMI, scanned notes, etc.)

\section{/12134500.20140725.578.flowtracker}

(The directory-naming format is stationNo.date.measurementNo.devicename; directory contains all FlowTracker ${ }^{\circledR}$ files, any field sheets—-for example, SWAMI, scanned notes, etc.)

Example illustrating file-naming conventions:
12134500.wad
12134500.ctl
12134500.dis
12134500.sum
12134500.dat

\section{/12134500.20140726.579.riverray}

(The directory-naming format is stationNo.date.measurementNo.devicename; directory contains all RiverRay files, Extrap files, etc., any field sheets-for example, SWAMI, scanned notes, etc.)

Example illustrating file-naming conventions:

12134500 579.mmt

12134500_579_000_12-05-11_105442.PD0

$12134500-579000-12-05-11105442$ ASC.TXT

$12134500 \quad 579000 \quad 12-05-11$ 105442 ASC20120524.lcf

12134500 579_001_12-05-11_111221.PD0

12134500_579_001_12-05-11_111221_ASC.TXT

$12134500-579002$ 12-05-11 111610.PD0

12134500_579_002_12-05-11_111610_ASC.TXT

\section{/12134500.20140912.inspection}

(The directory-naming format is stationNo.date.inspection; directory contains all files from a site visit. The site visit may have been for the purpose of a site inspection, collection of water-quality data, etc.; the directory contains all field sheets-for example, SWAMI, CHIMP, SVmobile, scanned notes, and measurements for QW data, etc. Note that SVmobile includes level data that also will need to be stored in the Levels subdirectory at $/ \mathbf{1 2 1 3 4 5 0 0 / L e v e l s . ) ~}$ 
Specifics for information under subdirectory /Record_Review

\section{/Record Review}

/Discharge

At this directory level, include files with information not tied to a specific review period, such as the file with datum/gage-height corrections. In this example, this file would be named

Datum-G.H.Corrections12134500.xlsx.

\section{/20140220-20140730}

(The directory-naming format is startingdate-endingdate of analysis period; directory contains all supporting documents for working/checking/reviewing the record - that is, data-correction worksheets, comparison hydrographs, weather records, questionable period plots, photo of log-jam on control, work-checkreview checklist.)

\section{SWR1_worked}

The above filename is a pdf-formatted file that includes all the SWreview pdfs produced by the worker.

\section{SWR2_checked}

The above filename is a pdf-formatted file that is only needed if the checker makes changes. This file includes all the SWreview pdfs produced by the checker. Note: Record changes from worker to checker need to be documented in RMS and on the checklist.

\section{SWR3_reviewed}

The above filename is a pdf-formatted file that includes all the SWreview pdfs produced by the reviewer. Note: Record changes from checker to reviewer need to be documented in RMS and on the checklist.

Note: SWR1_worked, SWR2_checked, and SWR3_reviewed may be consolidated into one pdf.

\section{/Precip}

\section{/date1-date2}

Similar as above.

The following directories refer to water-quality records that are subject to the guidance of the Quality-Assurance Plan for Water-Quality Activities in the U.S. Geological Survey Washington Water Science Center:

\section{/Sediment}

/date1-date2

Similar as above. 
/TDG

date1-date2

Similar as above.

/Nitrate (use this directory for a stand-alone sensor)

/date1-date2

Similar as above.

/WaterTemp (use this directory for a stand-alone sensor)

/date1-date2

WQMR1_worked

The above filename is a pdf-formatted file with the worked records.

WQMR2_checked

The above filename is a pdf-formatted file with the checked records. It is only needed if the checker makes changes.

\section{WQMR3_reviewed}

The above filename is a pdf-formatted file with the approved records.

Note: WQMR1_worked, WQMR2_checked, and WQMR3_reviewed may be consolidated into one pdf-formatted file.

/Turbidity (use this directory for a stand-alone sensor) /date1-date2

Instructions are the same as for /WaterTemp above.

/pH (use this directory for a stand-alone sensor)

/date1-date2

Instructions are the same as for /WaterTemp above.

/SpecCond (use this directory for a stand-alone sensor)

/date1-date2

Instructions are the same as for /WaterTemp above.

/DO (use this directory for a stand-alone sensor)

/date1-date2

Instructions are the same as for /WaterTemp above.

/QW-MultiParameter (use this directory for a multi-parameter sensor) /date1-date2

Directory contains one Microsoft Excel ${ }^{\circledR}$ file with all parameters and supporting documents. The multi-parameter Excel ${ }^{\circledR}$ file is generated by the worker. 


\section{/WaterTemp}

\section{WQMR1 worked}

The above filename is a pdf-formatted file with the worked records.

\section{WQMR2 checked}

The above filename is a pdf-formatted file with the checked records. It is only needed if the checker makes changes.

\section{WQMR3_reviewed}

The above filename is a pdf-formatted file with the approved records.

\section{Note: WQMR1_worked, WQMR2_checked, and WQMR3_reviewed may be consolidated into one pdf-formatted file.}

\section{/Turbidity}

Instructions are the same as for /WaterTemp above.

\section{$/ \mathbf{p H}$}

Instructions are the same as for /WaterTemp above.

\section{/SpecCond}

Instructions are the same as for /WaterTemp above.

\section{/DO}

Instructions are the same as for /WaterTemp above. 
The directory structure for our example station 12134500 is shown below in a graphic to further illustrate the structure listed above. The station is managed by the Northwest Washington Field Office and is a typical streamflow-gaging station with a pressure transducer for the stage sensor; therefore, there is no need for the "ADVM" upper level directory. Discharge is the only record being computed at this site, and in this example, it shows the directories for a review period from October 1, 2013, to February 3, 2014:
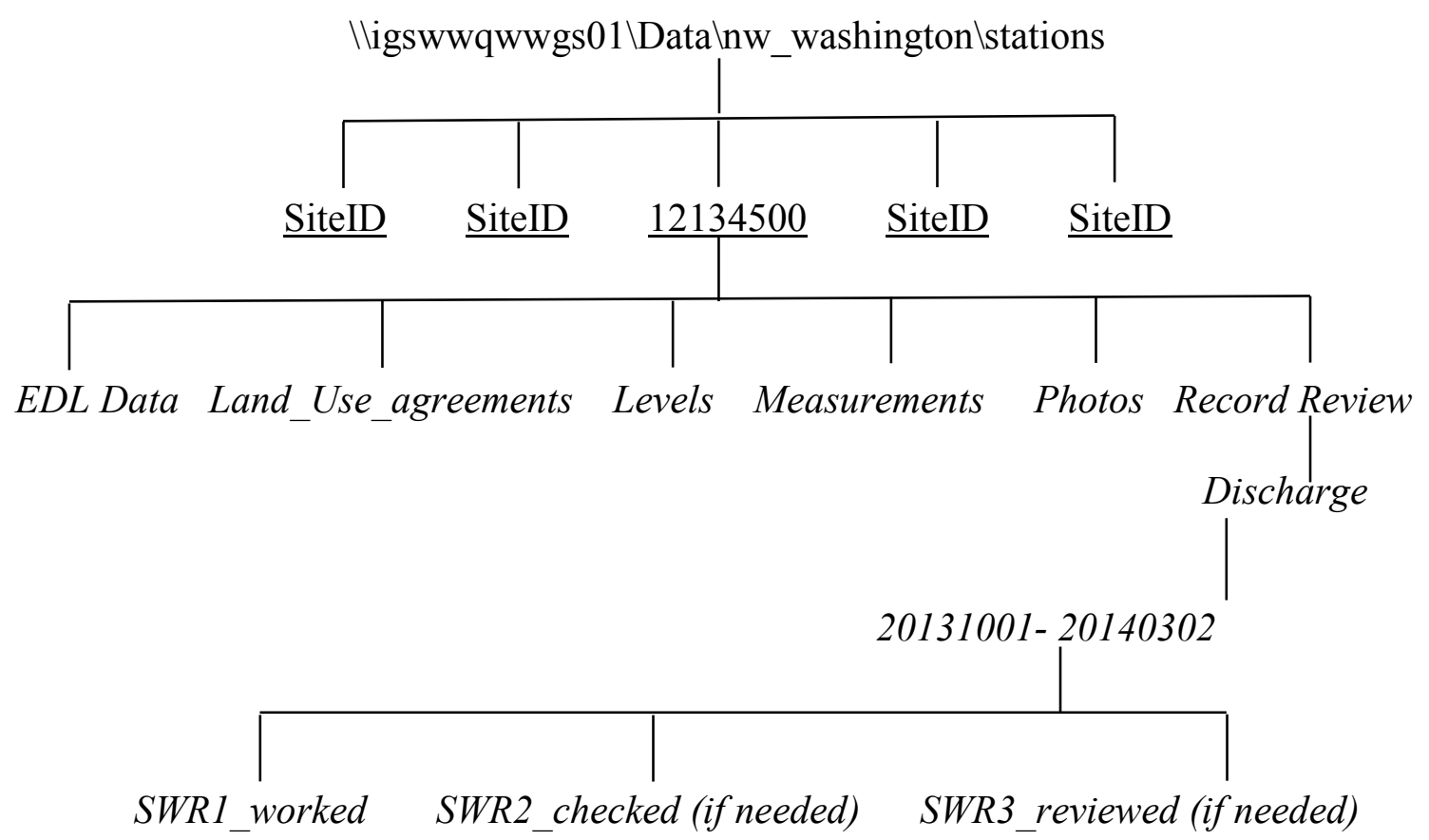

Publishing support provided by the U.S. Geological Survey

Science Publishing Network, Tacoma Publishing Service Center

For more information concerning the research in this report, contact the Director, Washington Water Science Center

U.S. Geological Survey

934 Broadway, Suite 300

Tacoma, Washington 98402

http://wa.water.usgs.gov 
